\title{
ANÁLISE DO SISTEMA DE MEDICAÇÃO DE UM HOSPITAL UNIVERSITÁRIO DO ESTADO DE
} GOIÁS

Ana Elisa Bauer de Camargo Silva

Dissertação apresentada à Escola de Enfermagem de Ribeirão Preto da Universidade de São Paulo para concorrer ao Título de Mestre em Enfermagem pelo Programa de Pós - Graduação - Área de concentração: Enfermagem Fundamental.

Ribeirão Preto 


\title{
ANÁLISE DO SISTEMA DE MEDICAÇÃO DE UM
}

\section{HOSPITAL UNIVERSITÁRIO DO ESTADO DE}

\section{GOIÁS}

\section{Ana Elisa Bauer de Camargo Silva}

\author{
Dissertação apresentada à Escola de Enfermagem \\ de Ribeirão Preto da Universidade de São Paulo \\ para concorrer ao Título de Mestre em \\ Enfermagem pelo Programa de Pós - Graduação \\ - Área de concentração: Enfermagem \\ Fundamental.
}

Orientadora: Prof ${ }^{a}$ Dr $^{a}$ Silvia Helena De Bortoli Cassiani

Ribeirão Preto 
FICHA CATALOGRÁFICA

Silva, Ana Elisa Bauer de Camargo

Análise do Sistema de Medicação de um Hospital Universitário do Estado de Goiás. Ribeirão Preto, 2003.

155 p: il., $30 \mathrm{~cm}$

Dissertação (Mestrado) - Escola de Enfermagem de Ribeirão Preto Universidade de São Paulo - Área de Concentração: Enfermagem

Fundamental.

Orientador: Prof ${ }^{a}$ Dr $^{a}$ Silvia Helena De Bortoli Cassiani

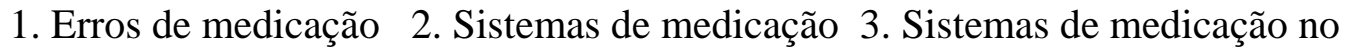
hospital 
Este trabalho está inserido na linha de pesquisa “Fundamentação teórica, metodológica e tecnológica do processo de cuidar em enfermagem" do Departamento de Enfermagem Geral e Especializada da Escola de Enfermagem de Ribeirão Preto Universidade de São Paulo. 
Data da defesa:

BANCA EXAMINADORA

Prof $^{a}$ Dr $^{\mathrm{a}}$ Silvia De Bortoli Cassiani

Julgamento:____ Assinatura:

Prof $^{\mathrm{a}}$ Dr $^{\mathrm{a}}$ Julieta Mieko Ueta

Julgamento:

Assinatura:

Prof $^{a}{ }^{\text {Dra }}{ }^{\mathrm{a}}$ Maria Luiza Anselmi

Julgamento:

Assinatura: 
"Seja qual for o teu sonho, comece.... Ousadia tem genialidade, poder e magia." 


\section{Dedicatória}

Aos meus pais, Ary e Vilma: meus mestres, meus maiores exemplos, meus grandes amores.

Ao Luiz Henrique, meu marido, pelo incentivo, compreensão e por sempre ter acreditado em meu potencial e em minha capacidade para vencer mais este desafio.

Aos meus irmãos e sobrinhos, que me realimentam com seu amor e alegria.

Aos meus grandes amigos de antes, durante, que também serão para sempre, os quais transformaram com seus sorrisos, gestos e palavras a possibilidade de uma trajetória árdua e solitária em uma caminhada alegre, enriquecedora, compartilhada, inesquecível: Ana Cláudia, Rita, Ju, Cristina, Juan, Martha, Regina, Claci, Edilomar. 


\section{Agradecimentos}

À Prof ${ }^{a}$ Dr $^{a}$ Silvia Helena De Bortoli Cassiani, por me abrir as portas para esta caminhada. Obrigada por sua firmeza, determinação, incentivo e confiança transmitidos e por compartilhar comigo os seus conhecimentos, nos momentos de orientação.

Às professoras Dra Maria Luiza Anselmi e Dra Julieta Mieko Ueta, pelas valiosas sugestões durante o exame de qualificação.

A toda minha família que sempre me deu o amor e incentivo que necessitava $e$ necessito para seguir em frente.

À dona Esther, tia Dora e Martha, que torceram e rezaram por mim.

À minha amiga Ana Cláudia que, nesse período, tornou-se uma irmã, dividindo, somando e compartilhando comigo cada momento de felicidade, de dúvida, de angústia, de alegria e de vida.

Aos amigos Denize, Marcelo, Virgínia, Maria, Marinésia, Ruth, Lizete, Renata, Gisele pela ajuda, conselhos e orientações nos momentos mais oportunos e decisivos desta etapa.

À Universidade Federal de Goiás, por possibilitar meu crescimento profissional e pessoal. 
À Faculdade de Enfermagem da Universidade Federal de Goiás e aos meus amigos professores, que permitiram e incentivaram este meu caminhar.

Ao Hospital das Clínicas da Universidade Federal de Goiás e seus profissionais, que me auxiliaram na realização deste estudo.

Aos auxiliares de pesquisa, pessoas fundamentais para realização deste estudo: Maria José, Neide, Ekissânia, Liliane e Neide.

Aos professores e funcionários da Escola de Enfermagem de Ribeirão Preto, pela eficiência e solicitude sempre demonstrada.

A todos que contribuíram para a execução deste trabalho, direta ou indiretamente, $e$ que não foram citados nominalmente, meu muito obrigada! 


\title{
SUMÁRIO
}

\author{
LISTA DE TABELAS \\ LISTA DE ABREVIATURAS \\ RESUMO \\ SUMMARY \\ RESUMÉN
}

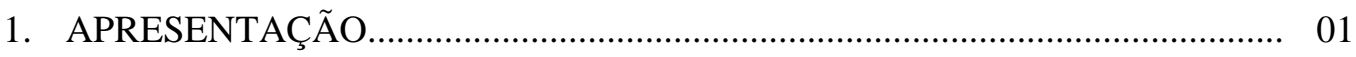

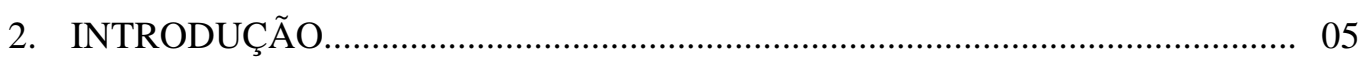

2.1. Definição, tipos, causas e medidas de prevenção dos erros na

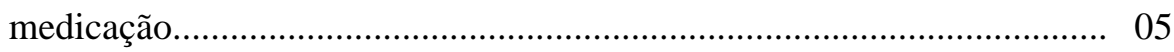

2.2. Sistema de medicação hospitalar................................................................ 15

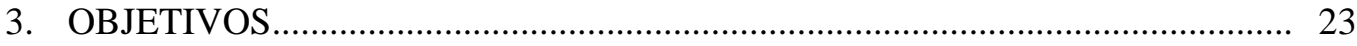

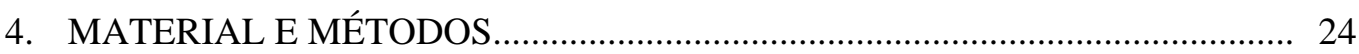

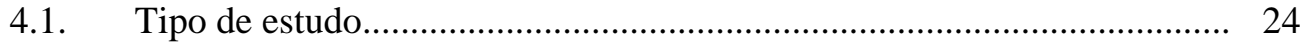

4.2. Local do estudo........................................................................... 24

4.3. População e amostra.......................................................................... 28

4.4. Procedimentos de coleta de dados......................................................... 29

4.4.1. Etapas, técnicas e procedimentos para coleta de dados................... 29

4.4.2. Treinamento dos auxiliares de pesquisa.......................................... 33

4.5. Ética na pesquisa................................................................................ 34

4.6. Organização e análise dos dados........................................................... 35

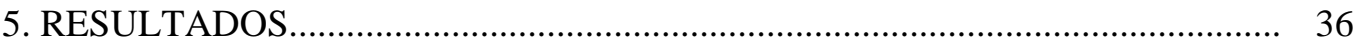

5.1. Apresentação do sistema de medicação.......................................................... 36

5.2. Análise do sistema de medicação quanto a falhas e problemas detectados

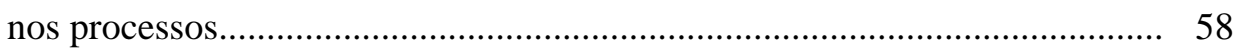

5.2.1. Falhas ou problemas detectados no processo de prescrição de medicamentos.

5.2.2. Falhas ou problemas detectados no processo de dispensação e distribuição de medicamentos.................................................................... 65

5.2.3. Falhas ou problemas detectados no processo de preparo e

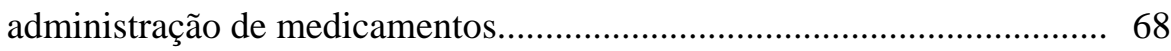

5.3. Erros na medicação: tipos, causas, providências e sugestões dos profissionais 
6. DISCUSSÃO.

6.1. Sistema de medicação.

6.2. Falhas e problemas detectados nos processos de medicação

6.2.1. Problemas identificados no processo de prescrições de medicamentos

6.2.2. Processo identificados no processo de dispensação e distribuição de medicamentos.

6.2.3. Problemas identificados no processo de administração de medicamentos

6.3. Erros na medicação: tipos, causas, providências, sugestões e de profissionais

7. SUGESTÕES PARA MELHORIAS NO SISTEMA DE MEDICAÇÃO DO HOSPITAL

8. CONCLUSÕES... 133

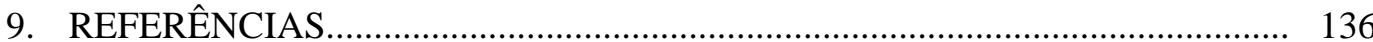

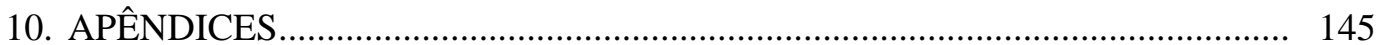

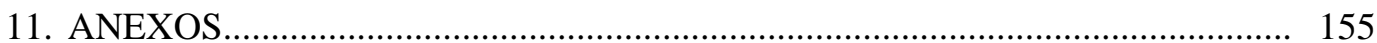




\section{Lista de Tabelas}

Tabela 1 Problemas identificados no processo de prescrição de medicamentos do sistema de medicação de um Hospital Universitário de Goiás, segundo categoria, descrição e freqüência de relatos. Goiânia, 2002

Tabela 2 Número e freqüência das características atribuídas às prescrições de medicamentos analisadas na unidade de clínica médica de um Hospital Universitário de Goiás. Goiânia, 2002

Tabela 3 Problemas identificados no processo de dispensação de medicamentos do sistema de medicação de um Hospital Universitário de Goiás, segundo categoria, descrição e freqüência de relatos. Goiânia, 2002

Tabela 4 Problemas identificados no processo de preparo e administração de medicamentos do sistema de medicação de um Hospital Universitário de Goiás, segundo categoria, descrição e freqüência de relatos. Goiânia, 2002

Tabela 5 Número e freqüência das características referentes às anotações de enfermagem encontradas nos prontuários médicos de pacientes da unidade de clínica médica de um Hospital Universitário de Goiás. Goiânia, 2002

Tabela 6 Número e freqüência de respostas referentes aos tipos de erros ou potencial para erros ocorridos na medicação, citados pelos profissionais entrevistados e distribuídos por categorias, em um Hospital Universitário de Goiás. Goiânia, 2002

Tabela 7 Número e freqüência de respostas referentes às opiniões dos profissionais sobre as causas de erros ocorridos na medicação, citadas pelos profissionais entrevistados e distribuídos por categorias, em um Hospital Universitário de Goiás. Goiânia, 2002

Tabela 8 Número e freqüência de respostas referentes às providencias administrativas tomadas pela instituição, relativas a erros ocorridos na medicação, citadas pelos profissionais entrevistados e distribuídas por categorias, em um Hospital Universitário de Goiás. Goiânia, 2002

Tabela 9 Número e freqüência de respostas referentes às sugestões para evitar erros ou potenciais para errar, citadas pelos profissionais entrevistados e distribuídas por categorias, em um Hospital Universitário de Goiás. Goiânia, 2002

Tabela 10 Número e freqüência de respostas referentes às opiniões sobre as falhas existentes no sistema de medicação, citadas pelos profissionais entrevistados e distribuídas por categorias, em um Hospital Universitário de Goiás. Goiânia, 2002 


\section{Lista de Abreviaturas e Siglas}

$\begin{array}{ll}\text { ASHP } & \text { American Society of Health- System Pharmacists } \\ \text { CCIH } & \text { Comissão de Controle de Infecção Hospitalar } \\ \text { CRM } & \text { Conselho Regional de Medicina } \\ \text { DEF } & \text { Dicionário de Especialidades Farmacêuticas } \\ \text { EUA } & \text { Estados Unidos da América } \\ \text { FC } & \text { Freqüência Cardíaca } \\ \text { JCAHO } & \text { Joint Commission on Accreditation of Healthcare Organizations } \\ \text { NCCMERP } & \text { National Coordinating Council for Medication Error Reporting } \\ \text { PA } & \text { and Prevention } \\ \text { PM } & \text { Pressão Arterial } \\ \text { PP } & \text { Posto de Medicação } \\ \text { SC } & \text { Posto de Preparo } \\ \text { SF } & \text { Subcutânea } \\ & \text { Soro Fisiológico } \\ \text { UTIdade de Tratamento Intensivo }\end{array}$




\section{RESUMO}

SILVA, A. E. B. C. Análise do sistema de medicação de um hospital universitário do Estado de Goiás. 2003. 190p. Dissertação Mestrado - Escola de Enfermagem de Ribeirão Preto, Universidade de São Paulo, Ribeirão Preto.

Os erros na medicação podem trazer sérias conseqüências aos pacientes, profissionais e às instituições de saúde; resultando de múltiplas causas, dentre elas: falhas profissionais e do sistema de medicação. O objetivo deste estudo foi identificar e analisar os processos do sistema de medicação, suas falhas e propor medidas de melhorias ao hospital. Realizou-se uma pesquisa quantitativa do tipo survey exploratório, na unidade de clínica médica e na farmácia de um hospital geral e universitário do estado de Goiás, após aprovação do Comitê de Ética em Pesquisa. A amostra constituiu-se de um farmacêutico na primeira etapa, 40 profissionais na terceira etapa, sendo 12 (30\%) médicos-residentes; 20 (50\%) profissionais de enfermagem e 8 (20\%) profissionais da equipe de farmácia, além da utilização de 294 prontuários. Realizou-se a coleta dos dados em 2002, por meio de entrevista com o responsável pelo sistema de medicação da instituição; de observação não-participante de ambientes e de ações dos profissionais e acadêmicos; de entrevista com profissionais e de análise de prontuários. Consultaram-se todos os profissionais quanto à sua disposição para participar do estudo e, a seguir, solicitou-se a assinatura do termo de consentimento livre e esclarecido. Os dados obtidos possibilitaram caracterizar os seguintes processos: prescrição de medicamentos realizada manualmente com cópia carbonada, dispensação por dose individualizada, além de indicar que o profissional de enfermagem que administra o medicamento não é o mesmo que o prepara, na clínica médica. Os resultados das observações realizadas durante 21 dias, nos processos de prescrição, dispensação e administração de medicamentos, indicaram: o ambiente como principal problema no processo de prescrição (69\%) e de dispensação de medicamentos $(30,6 \%)$, por se tratar de local impróprio, com ruídos e interrupções freqüentes; falhas na segurança durante a técnica e preparo antecipado do medicamento no processo de preparação (46,8\%). O estudo possibilitou, também, a construção de um gráfico do fluxo das 60 ações desenvolvidas desde a prescrição até o monitoramento. As entrevistas com os profissionais apontaram que os tipos de erros mais freqüentes estavam relacionados à prescrição médica (29\%) e ao horário (20,6\%); suas causas deviam-se a falhas individuais e falta de atenção $(47,4 \%)$ e excesso de trabalho (14,5\%). As falhas individuais dos profissionais foram apontadas também como principal falha do sistema de medicação (27\%). A alteração nas atitudes individuais foi a sugestão mais indicada para evitar a ocorrência de erros, com $28,3 \%$ das respostas, e a orientação, a providência mais tomada (25\%). A análise dos prontuários mostrou prescrições de medicamentos com 64,6\% de legibilidade, tendo 62,2\% tanto nomes de medicamentos comerciais quanto do princípio ativo; 95\% estavam incompletas para algum item; 96\% apresentavam abreviaturas e 30\% rasuras. Encontraram-se anotações sobre medicamentos apenas em sete relatos de enfermagem e uma outra na evolução médica. A clínica não possui relatório de ocorrências sobre erros na medicação. As medidas propostas para melhorar o sistema e, conseqüentemente, prevenir erros na medicação foram: prescrição eletrônica, dose unitária, relatórios sobre erros, cultura não-punitiva, segurança do paciente e, enfim, simplificação do sistema.

Palavras chave: Erros de medicação. Sistemas de medicação. Sistemas de medicação no hospital 


\section{SUMMARY}

SILVA, A. E. B. C. Medication system analysis of an university hospital in the State of Goiás 2003. 190p. Dissertação Mestrado - Escola de Enfermagem de Ribeirão Preto, Universidade de São Paulo, Ribeirão Preto.

The medication errors can bring serious consequences to patients, professionals and healthcare institutions, they have multiple causes, amongst them failures related to the professionals and related to the medication system. This study's objective was to identify and to analyse the medication system process, its failures in order to propose improvement actions to the hospital. This exploratory descriptive study took place in the medical clinical unit and in the pharmacy of a general and university hospital of the state of Goiás, after approval of the Committee of the Ethics of the correspondent hospital. The sample included: (first phase) a pharmacist, (third phase) 40 professionals divided into 12 resident physicians (30\%), 20 nursing professionals (50\%), 8 pharmacy team members (20\%); 294 patient charts were also used. The data was collected in 2002 and consisted of an interview with the professional in charge of the medication system, and non-participant observation of the environment and actions of the professionals and the academic people, interviews with the professionals and patient chart analysis. The professionals were asked to sign on the "Free Will Participation Agreement”. It was possible based on the data collected to describe the following processes: handwriting medication prescription using carbon paper, individually dose dispensing and that the nursing professional who administrates the drug is not the same that prepares it in the clinical unit. The results based on the 21 days of observation of the drug prescription, dispensing and administration processes were: the environment is the main problem in the prescription (69\%) and dispensing (30,6\%) processes, it is a noisy place and interruptions frequently occur; safety failures during the technique and in-advance drug preparation appeared in the top $(46,8 \%)$ in the preparation process. The data collection also allowed to build a chart of the 60 steps from drug prescription to monitoring. The results from the interviews showed that the most frequent errors were related to both prescription (29\%) and schedule $(20,6 \%)$ and their main cause were individual failures and lack of attention $(47,7 \%)$ and work overload (14,5\%). The individual failures were also listed as the main failure in the medication system (27\%). In order to avoid errors $28,3 \%$ of the answers suggested to change the individuals' behavior, and orientation as the administrative action more frequently taken (25\%). The patient chart analysis found out the following drug prescriptions characteristics: $64,6 \%$ readable, $62,2 \%$ using drug brand names as well as the active principle name, 95\% incomplete for missing information, $96 \%$ using abbreviations and $30 \%$ with erasures. Concerning to drug notifications, the analysis also found out 7 nursing reports, one from the physician and that there is no error report in the clinical unit. The suggested improvements to avoid errors and enhance the system are: computerized physician order electronic entry, unit dose, errors reports, non-punitive approach, patient safety, and at last to make the system as simple and lean as possible.

Key-words: Medication errors. Medication system. Medication system., hospital 


\section{RESUMÉN}

SILVA, A. E. B. C. Análisis del sistema de medicación de un hospital universitario en el estado de Goiás. 2003. 190p. Dissertação Mestrado - Escola de Enfermagem de Ribeirão Preto, Universidade de São Paulo, Ribeirão Preto.

Errores en la medicación pueden traer consecuencias a pacientes, a profesionales, y a las instituciones de salud y resultan de múltiples causas, entre ellas, fallas profesionales y del sistema de medicación. El objetivo del estudio fue identificar y analizar los procesos del sistema de medicación, sus fallas y proponer medidas de mejoría al hospital. La investigación fue cuantitativa tipo survey exploratorio, en la unidad de clínica médica y en la farmacia de un hospital universitario del estado de Goiás, después de ser aprobada por el Comité de Ética. La muestra se conformó por 40 profesionales: 12 médicos residentes; 20 enfermeros, 9 de farmacia; además de utilizarse, 294 expedientes. La recolección de datos fue realizada en el 2002 a través de entrevista con el responsable del sistema de medicación del hospital y con profesionales, observación no participante de ambientes y acciones de profesionales y académicos, y análisis de expedientes. Se consultaron a los profesionales que estuvieron dispuestos a participar, después de firmar el consentimiento informado. Los resultados permitieron caracterizar los procesos: prescripción de medicamentos en forma manual con copia al carbón, entrega de dosis individualizada, además de señalar que el profesional de enfermería que administra el medicamento no es el mismo que lo prepara. Los resultados de observaciones realizadas durante 21 días, en los procesos de prescripción, entrega y administración de medicamentos, indicaron problemas: el ambiente como principal problema en el proceso de prescripción (69\%), de entrega de medicamentos (30.6\%) por tratarse de un local inapropiado, con ruidos e interrupciones frecuentes; fallas en la seguridad durante la técnica y preparación anticipada en el proceso de preparación del medicamento (46,8\%). El estudio permitió construir fluxograma de las 60 acciones desarrolladas desde la prescripción hasta el monitoreo. Las entrevistas con profesionales mostraron que los errores más frecuentes estaban relacionados a la prescripción médica (29\%), al horario (20.6\%); sus causas se debían a fallas individuales y a falta de atención (47.4\%), además de exceso de trabajo (14.5\%). Las fallas individuales de profesionales aparecen también como principal falla del sistema de medicación (27\%). Se sugirió modificación en las actitudes individuales para evitar ocurrencia de errores en $28.3 \%$ de las respuestas, y la orientación fue la acción más utilizada (25\%). El análisis de expedientes, mostró prescripciones legibles de medicamentos en $64.6 \%$, siendo que $62.2 \%$ utilizaron tanto nombres de medicamentos comerciales como del principio activo; 95\% estuvieron incompletas en algún ítem, 96\% utilizaron abreviaturas y $30 \%$ tenían correcciones. Anotaciones sobre medicamentos fueron encontradas en siete relatos de enfermería y una en la evolución médica. No hay en la clínica informe de ocurrencia sobre errores en la medicación. Las medidas propuestas para mejorar el sistema y así prevenir errores en la medicación, fueron: prescripción electrónica, dosis unitaria, informe sobre errores, cultura no punitiva, seguridad del paciente y simplificación del sistema.

Palabras Clave: Errores de medicación. Sistemas de medicación. Sistemas de medicación en el hospital. 


\section{APRESENTAÇÃO}

O exercício da prática de enfermagem, seja na área assistencial hospitalar ou na docência, permitiu que testemunhássemos a ocorrência de erros no processo de medicação dos pacientes ou ainda que estiveram na eminência de ocorrer e que, após um alerta, foram evitados.

Como enfermeira assistencial, nossa preocupação em relação aos erros na medicação centrava-se em ações específicas da enfermagem, como a busca de conhecimento sobre fármacos, interações medicamentosas, treinamento de técnicas pela equipe de enfermagem, fiscalização, enfim, em ações pontuais voltadas aos profissionais que atuam na linha de frente da assistência e que são responsáveis pelo último passo no processo de medicação do paciente, que é a administração de medicamentos.

Sem dúvida, essa é uma visão fracionada do problema, pois nesse sistema complexo previamente configurado e estabelecido, responsável pela medicação do paciente, o profissional de enfermagem atua apenas numa parte.

Para este pesquisador, assumir o cargo de docente em uma Faculdade de Enfermagem e ministrar uma disciplina na qual um dos conteúdos exigidos era Administração de Medicamentos, e associar esta nova atividade à maturidade, experiência profissional e responsabilidade, adquiridas ao longo dos anos, fez com 
que várias questões que cercam o ato de medicar e os possíveis erros cometidos nesse ato viessem à tona.

Nessa trajetória, sentimos que a responsabilidade pela introdução dos acadêmicos de enfermagem na prática da administração de medicamentos em instituição hospitalar exigia do profissional uma visão ampla do sistema de medicação existente, não só para lhes garantir um ensino integral, como também uma assistência responsável e segura ao paciente.

Na função de educadora, devemos buscar o domínio de determinados conteúdos e situações para que possamos, com firmeza e propriedade, transmiti-los ao aluno, estimulando-o a questionar a respeito dos mesmos, promovendo assim uma formação acadêmica que lhe permita analisar o contexto estudado.

No processo de ensino não devemos nos ater somente aos procedimentos técnicos e básicos inerentes à profissão, mas, sim, estimular o aluno a buscar o conhecimento, no caso específico de medicamento, permitir que identifique os caminhos percorridos por ele desde o momento que o médico o prescreve até a sua administração ao paciente e, também, analisar criticamente o sistema de medicação e refletir sobre as possíveis falhas, causas, alternativas e soluções.

Durante as aulas práticas de administração de medicamentos ministradas no hospital, surgiam, tanto para o docente como para os alunos, dificuldades e questionamentos a respeito das rotinas, procedimentos utilizados no sistema de medicação; estes também demonstravam desconhecimento das estratégias organizacionais disponíveis para prevenção, tratamento e registro dos erros na medicação, fato este que dava a impressão de maior exposição ao erro. 
Assim, surgiu a oportunidade de integrarmos um projeto temático de pesquisa multicêntrico, coordenado pela orientadora desta pesquisa, e financiado pela Fundação de Amparo à Pesquisa do Estado de São Paulo (FAPESP), cujo objetivo era identificar e analisar falhas no sistema que pudessem induzir a erros na medicação em 04 hospitais localizados nas regiões Sudeste, Centro-oeste e Nordeste do Brasil. Este estudo permitiria, também que analisássemos o sistema de medicação em vigência no hospital universitário no qual atuamos supervisionando alunos de graduação em enfermagem, com intuito de colaborar com avanços e melhorias ao ensino, à organização hospitalar e à enfermagem.

Conhecer o sistema de medicação existente na instituição, suas limitações, assim como o papel que cada indivíduo desempenha nos diversos processos, facilitará a execução das atividades dos docentes, de acadêmicos e demais profissionais que dele façam parte, proporcionando maior segurança ao paciente.

Quando alunos e profissionais compreenderem que o ato de medicar um paciente é uma atividade multi e interdisciplinar, da qual participam médicos, equipe de enfermagem e farmácia, e na qual as ações são interligadas e dependentes entre si, o relacionamento interpessoal deverá transcorrer com maior segurança, desenvolvendo senso crítico e responsabilidade, pois todos se sentirão como partes de um sistema que visa a um objetivo final, e perceberão que desempenham importante papel, e não apenas o de cumpridores de ordens. Enfim, esse conjunto de fatores auxiliará a integração no ambiente que recebe, abriga e oferece seu espaço e infra-estrutura para o desenvolvimento das atividades acadêmicas.

Acreditamos que o conhecimento advindo deste estudo permitirá potencializar as ações já desenvolvidas pela instituição visando à qualidade do 
sistema de medicação. E isso ocorrerá através de ações educativas voltadas aos estagiários e profissionais de saúde das diversas áreas; de idéias que venham se somar àquelas já em execução e da participação dos profissionais na avaliação das atividades existentes, procurando prevenir erros na medicação e assim restaurar a saúde dos pacientes com uma terapêutica medicamentosa responsável e segura.

Considerando que a incidência de erros na medicação constitui um dos indicadores de qualidade da assistência prestada ao paciente (SCHNEIDER \& GIFT, 1998; CARVALHO, 2000), este estudo estará auxiliando a instituição em questão, na busca da melhoria da qualidade da assistência prestada aos seus clientes, ao identificar possíveis fragilidades no sistema de medicação procurando reestruturá-lo com vistas a lhe dar maior eficiência.

Devemos considerar a enfermagem tem muito ainda a desenvolver em relação a essa temática, tanto em nível nacional como internacionalmente, mesmo porque a maior parte dos estudos apresentados na literatura é de profissionais da farmácia (PEPPER, 1995; MIASSO \& CASSIANI, 2000).

Por todos os motivos citados, este trabalho pretende ser de grande valia tanto para a categoria de enfermagem, como para a Faculdade de Enfermagem na qual lecionamos e também para o hospital que possibilitou a sua realização. 


\section{INTRODUÇÃO}

2.1. Definição, tipos, causas e medidas de prevenção dos erros na medicação.

Os medicamentos, há séculos, vêm sendo utilizados com a intenção de aliviar, combater a dor ou curar doenças; no entanto, estudos, ao longo dos últimos anos, têm evidenciado a presença de erros no tratamento medicamentoso recebido pelos pacientes, causando prejuízos que vão desde o não-recebimento, por parte dos pacientes, do medicamento necessário até lesões e mortes (ALLAN \& BARKER, 1990; LEAPE et al. 1995; CARVALHO et al., 1999; TÁXIS \& BARBER, 2003).

Os profissionais de saúde envolvidos com a terapêutica devem estar cientes e alertas para este fato e buscar, permanentemente, medidas de prevenção de erros, seja através de novos conhecimentos e condutas ou de estratégias que visem proteger todos os envolvidos, principalmente o paciente.

Nesse caso, importa, primeiramente, definir e distinguir alguns termos utilizados quando nos reportamos a medicamentos, como: eventos adversos ao medicamento, reações adversas ao medicamento, erro na medicação e evento adverso potencial ao medicamento.

O termo “evento adverso ao medicamento" é descrito como o acontecimento no qual o medicamento causou dano ao paciente, podendo neste caso ser passível ou não de prevenção (GANDHI et al., 2000). 
Reação adversa ao medicamento, segundo a Organização Mundial de Saúde, é qualquer dano causado pela medicação, porém aqui não se incluem os eventos associados a erros.

A definição de reação adversa ao medicamento para Van den Bemt et al. (2000), após revisão de 84 artigos sobre os diferentes tipos de problemas relacionados a medicamentos, refere-se a "qualquer resposta nociva ou indesejada ao medicamento, que ocorre na dose normalmente usada para profilaxia, diagnóstico ou tratamento de doença, ou para modificação de função fisiológica, mas não devido a um erro na medicação” (VAN DEN BEMT et al., 2000).

Como exemplo de uma reação adversa citamos uma reação alérgica, desconhecida até então pelos profissionais e pelo próprio paciente, provinda de um determinado fármaco (anestésico, contraste iodado etc). A reação alérgica ou o dano, neste caso, é imprevisível e inevitável, portanto, sem condições de ser prevenida.

Os erros na medicação são considerados eventos adversos ao medicamento passíveis de prevenção, podendo ou não causar dano ao paciente, com possibilidade de ocorrer em um ou em vários momentos dentro do processo de medicação.

Com o intuito de prevenir erros na medicação, disseminar conhecimento e estimular os relatos dos erros, foi fundado em 1995, pela United States Pharmacopeia o National Coordinating Council for Medication Error Reporting and Prevention (NCCMERP), corporação norte - americana independente, composta de 15 organizações, que apresenta as seguintes definições para dano e erro na medicação: 
"Dano é definido como prejuízo temporário ou permanente da função ou estrutura do corpo: física, emocional, ou psicológica, seguida ou não de dor, requerendo uma intervenção".

"Erro na medicação é qualquer evento evitável que pode causar ou induzir ao uso inapropriado de medicamento ou prejudicar o paciente enquanto o medicamento está sob o controle do profissional de saúde, paciente ou consumidor. Tais eventos podem estar relacionados à prática profissional, produtos de cuidado de saúde, procedimentos, e sistemas, incluindo prescrição; comunicação; etiquetação, embalagem e nomenclatura; aviamento; dispensação; distribuição; administração; educação; monitoramento e uso". (NCCMERP, 1998).

Já o evento adverso potencial ao medicamento é aquele em que o erro ocorreu, mas que por alguma razão não causou dano ao paciente. Todos os eventos adversos potenciais referem-se a erros na medicação (CASSIANI, 2000B; GANDHI et al., 2000).

Os dados mostram que os erros na medicação representam uma triste realidade no trabalho dos profissionais de saúde, com sérias conseqüências para pacientes e organização hospitalar, pois suas causas repercutem negativamente nos resultados institucionais face aos indicadores relevantes da qualidade da assistência prestada aos pacientes hospitalizados (CARVALHO, 2000).

O Institute of Medicine (EUA), que tem como missão gerar e disseminar conhecimento científico para melhorar a saúde do ser humano, criou em 1998 o projeto Quality of Health Care in América (QHCA), cujas metas são prover liderança, direção estratégica e ferramentas analíticas, visando contribuir também para a melhoria da qualidade do cuidado médico. Em novembro de 1999 o comitê lançou seu primeiro relatório intitulado “To err is human: building a safer health 
system”, que tem sido referência para muitos estudos (FLYN et al., 2002; LEE, 2002; CASSIANI et al., 2002).

Esse relatório, baseado em estudos realizados no Colorado, Utah e Nova York, aponta que das 33,6 milhões de internações realizadas no ano de 1997, em hospitais dos EUA, por volta de 44.000 a 98.000 americanos morreram devido a problemas causados por erros na medicação (KOHN et al., 2001).

Estudo realizado em dois hospitais terciários de grande porte, Brighan and Women's Hospital e Massachuchusetts General Hospital, nos Estados Unidos da América, apontou uma média de 6,5 eventos adversos ao medicamento para cada 100 internações, dos quais 28\% poderiam ter sido prevenidos (BATES et al., 1995). Um outro que estudou 36 hospitais e instalações de saúde, também realizado nos EUA, identificou que $19 \%$ das doses administradas estavam erradas, tendo como erros mais freqüentes: horário errado (43\%), omissão (30\%), dose errada (17\%) e aplicação de medicamento sem autorização (4\%) (BARKER et al., 2002).

Em pesquisa desenvolvida na enfermaria de cardiologia do Duke University Hospital, no período de 1995 a 2000, os autores avaliaram 14.983 intervenções feitas por farmacêuticos clínicos nas condutas da terapia medicamentosa e constataram que 4.768 delas estavam associadas a erros na medicação, que puderam ser prevenidos. Tal índice apontou um total de 24 erros para cada 100 pacientes internados (LAPOINTE \& JOLLIS, 2003).

Os erros na medicação podem, muitas vezes, causar dano ao paciente e, segundo Bates (1996), cerca de 30\% dos danos durante a hospitalização estão associadas a erros na medicação, os quais trazem também sérias conseqüências econômicas às instituições de saúde. O autor salienta que, devido ao uso freqüente de 
medicamentos, o número total de danos evitáveis torna-se significativo e caro. Estima-se um gasto de aproximadamente US\$ 4.700 por evento adverso de medicamento evitável ou por volta de US\$ 2,8 milhões, anualmente, em um hospital de ensino com 700 leitos. O custo anual de morbidade e mortalidade referente a erros na medicação, nos EUA, tem sido estimado em torno de US\$ 76,6 bilhões (BERWICK \& LEAPE, 1999; KOHN et al., 2001, ANDERSON, 2002).

Vários fatores colaboram para o aumento dos erros, e um deles é o grande número de medicamentos lançados no mercado, exigindo dos profissionais constante atualização sobre posologia, diluição, interações medicamentosas e técnicas de administração, bem como a existência de maior complexidade na terapêutica.

Estudos sobre a incidência de erros na medicação e a busca por maior segurança no processo de distribuição e administração dos mesmos, nos EUA, tiveram início na década de 50, impulsionados pelo aumento do uso de medicamentos com novas formas farmacêuticas, mais potentes e capazes de dominar muitas doenças, exigindo dos profissionais maior conhecimento (RIBEIRO, 1991). Entretanto, no Brasil, somente na década de 90 é que proliferaram estudos sobre o tema.

No entanto, muitos erros na medicação ainda não são detectados nos hospitais, pois há subnotificação de sua ocorrência devido à inexistência de relatórios padronizados e ao medo da punição (OSBORNE et al., 1999). Outra situação que leva à subnotificação dos erros cometidos refere-se ao conceito restrito dos profissionais sobre o que seja erro na medicação (CASSIANI, 2000a). 
Os erros descritos tanto na literatura nacional como na internacional são tipados conforme descrição a seguir (RIBEIRO, 1991; DRAFT, 1992; CASSIANI, 1998, NCCMERP, 1998):

- Erros de omissão: qualquer dose não-administrada até o próximo horário de medicação.

- Erros na administração de um medicamento não-autorizado: administração de um medicamento ou dose de medicamento não-prescrito pelo médico.

- Erros em dose extra: administração de uma ou mais unidades de dosagem, além daquela prescrita.

- Erros referentes à via: administração pela via errada ou por uma via que não a prescrita.

- Erros com a dosagem: administração do medicamento em dosagens diferentes daquelas prescritas pelo médico.

- Erros devido ao horário incorreto: administrar medicamento fora dos horários predefinidos pela instituição ou da prescrição.

- Erros devido ao preparo incorreto do medicamento: medicamento incorretamente formulado ou manipulado: diluição ou reconstituição incorreta ou inexata; falha ao agitar suspensões; diluição de medicamentos que não permitam esse procedimento, mistura de medicamentos que são física ou quimicamente incompatíveis e embalagem inadequada do produto.

- Erros devido à utilização de técnicas incorretas na administração: uso de procedimentos inconvenientes ou técnicas impróprias, como falhas nas técnicas de assepsia e das lavagens das mãos. 
- Erros com medicamentos deteriorados: administração de medicamentos com comprometimento da integridade física ou química.

- Outros tipos de erros incluem:

- Erros de prescrição: prescrição imprópria de um medicamento, seja em relação à dose, apresentação, quantidade, via de administração ou concentração.

- Erros de distribuição: falhas ao distribuir o medicamento, como: doses incorretas; rótulos incorretos ou inadequados; preparação incorreta ou inapropriada; distribuição de medicamento com data expirada; medicamento estocado de maneira imprópria ou ainda comprometido física ou quimicamente.

- Erros potenciais: são aqueles que ocorreram na prescrição, distribuição ou administração dos medicamentos, mas que não causaram dano ao paciente.

Medicar o paciente, atividade exercida por profissionais de saúde que têm como base de trabalho as relações humanas, requer um processo de comunicação eficaz para que obtenha sucesso. Problemas na comunicação podem ser uma das causas de erros na medicação, e se originam de várias situações encontradas no diaa-dia do profissional (BARKER \& HELLER, 1964 apud RIBEIRO, 1991, p. 70). Dentre essas situações, a má qualidade da letra médica é identificada como um fator que contribui não só para a incidência de erros, como também para aumentar o custo para o hospital, pois exige mais tempo da enfermagem e dos profissionais da farmácia para interpretá-la. A falta de uma padronização da nomenclatura de medicamentos também pode gerar problemas, pois muitos deles possuem nomes comerciais parecidos, podendo ser transcritos ou interpretados de maneira incorreta. 
Além disso, o uso de abreviaturas nas prescrições, padronizadas ou não, podem originar erros.

As ordens verbais são freqüentes na prática hospitalar, principalmente em situações de emergência, porém exigem uma boa memória do receptor para guardar a dose e nome do medicamento indicado, pois muitas vezes elas são dadas de forma incompleta, com omissão de informações; no caso das prescrições escritas, as informações podem ser também incompletas e faltar dados como: via, dose, posologia, diluição, levando o profissional a tirar conclusões próprias sobre como agir, seja executando ou deixando de realizar o procedimento.

Em alguns hospitais é comum o ato de transcrições das ordens médicas que podem induzir à omissão ou erro na transmissão da informação. Outras dificuldades encontradas pelos profissionais referem-se à interpretação das prescrições e anotações sobre dosagens, como mcg, mg, com as virgulas ou pontos decimais da dosagem.

Os erros na medicação, na prática profissional, também podem estar relacionados: a deficiências da formação acadêmica, inexperiência, negligência, desatenção ou desatualização quanto aos avanços tecnológicos e científicos; ao manejo de equipamentos, como bombas de infusão, cateteres etc; aos procedimentos desenvolvidos e ao sistema de medicação como um todo.

Medicar pacientes depende de ações meramente humanas e os erros fazem parte dessa natureza, porém um sistema de medicação bem estruturado deverá promover condições que auxiliem na minimização e prevenção dos erros, implementando normas, regras, ações, processos com a finalidade de auxiliar os profissionais envolvidos. 
Alguns estudos têm como propósitos identificar e analisar os erros na medicação, mas o fazem sob a ótica dos erros causados pelos profissionais, ignorando que erros na medicação também podem ser gerados por falhas no sistema que, muitas vezes, induzem ao erro humano (BRENNAM, 1991; PHELAN, 1996).

A administração da qualidade total prega que problemas na qualidade acarretam falhas nos processos influenciando as ações dos profissionais, levando-os a errar. No caso do erro na medicação, o indivíduo raramente é a única causa. Desse modo, entendemos que deve-se mudar a cultura dos erros para que estes não sejam vistos como falhas humanas, mas como uma oportunidade de melhorar o sistema existente (BERWICK, 1994; LEAPE, 1994; PEPPER, 1995).

No momento em que a instituição procurar saber “como” e o "por quê” da ocorrência dos erros, e não mais o “quem” foi o responsável por eles, ela contará com a colaboração dos profissionais para diagnosticar as falhas que possam estar ocorrendo na medicação dos pacientes. Portanto, é necessário que seja disseminada e reforçada nas instituições de saúde a importância da confecção de relatórios sobre as ocorrências de erros na medicação, para que as causas e os problemas sejam identificados e medidas sejam tomadas a fim de diminuir sua incidência. Sabemos que o medo de ações disciplinares e punitivas compromete a decisão do funcionário ou da equipe quanto a documentá-lo ou não (CASSIANI, 1998). Assim para estimular a confecção de relatórios que registrem os erros na medicação, os gerentes de serviços devem mudar sua cultura, como também promover mudanças no ambiente de trabalho, de modo que a punição não seja a prática em execução e o ser humano não seja o foco principal de correção (CASSIANI, 2000b). 
A busca da qualidade nos serviços hospitalares sugere reconhecer falhas no processo e a disposição em repará-las, ao invés de se preocupar com a punição dos trabalhadores. O foco dos esforços para melhoria da qualidade não deve centrar-se nas pessoas que participam de um processo falho, mas nos processos que fazem as falhas acontecerem (BERWICK, 1994).

Os gerentes muitas vezes pensam que, sem punição, os profissionais se tornarão descuidados e com isso os erros poderão aumentar, mas Womer et al. (2002), em estudo realizado sobre a prática da não-punição no Children’s Hospital of Philadelphia, identificaram que os relatos de erros interceptados aumentaram dramaticamente enquanto os dos detectados diminuíram.

Como percebemos várias são as condutas e alternativas a serem tomadas para minimizar e/ou prevenir a ocorrência de erros na medicação do paciente.

Uma equipe multidisciplinar nomeada pela American Society of Hospital Pharmacists - ASHP, American Medical Association (AMA) e American Nurses Association (ANA) identificou ações para prevenir eventos adversos ao medicamento e sugeriu algumas estratégias, como as que se seguem (AMERICAN SOCIETY OF HOSPITAL PHARMACISTS - ASHP, 1996):

1. Estabelecer processos de prescrição de medicamentos diretamente em sistema computadorizado.

2. Avaliar o uso de máquinas de leitura de códigos de barra no processo de medicação.

3. Desenvolver sistemas mais efetivos para monitorar e relatar os eventos adversos ao medicamento. 
4. Utilizar distribuição dos medicamentos em doses unitárias e fazer a preparação na farmácia dos medicamentos injetados por via endovenosa.

5. Designar farmacêuticos para atuarem em áreas de cuidado dos pacientes em colaboração direta com médicos e equipe de enfermagem.

6. Abordar os erros na medicação, como uma falha do sistema, e buscar soluções para preveni-los.

7. Assegurar que as prescrições sejam rotineiramente revisadas pelos farmacêuticos antes das primeiras doses.

Estas e outras estratégias devem ser implantadas no sistema de medicação desenvolvido pela administração de um hospital, com o intuito de levar o medicamento até o paciente de maneira eficaz. O sistema de medicação envolve várias etapas que estão inter-relacionadas e interligadas por várias ações e por vários profissionais, as quais abordaremos a seguir.

\subsection{Sistema de Medicação Hospitalar}

A teoria geral dos sistemas, que em sentido amplo tem o caráter de uma ciência básica e no sentido restrito sugere um complexo de componentes em interação, surgiu por volta de 1930, quando a biologia discutia o organismo vivo em partes, como se fosse um agregado de células. Bertallanfy e outros biólogos alteraram esta forma de pensar partindo do princípio que um ser vivo não é simplesmente um aglomerado de elementos, sem integridade e organização (BERTALANFFY, 1977). 
O conceito de sistema traz as relações entre as partes e o todo, permitindo a compreensão de toda e qualquer atividade complexa, sendo os sistemas constituídos de conjuntos de componentes que se interagem, se inter-relacionam, se transformam e atuam entre si na execução de um objetivo global. Estes conjuntos poderão ser assumidos como subsistemas ou processos, com funções e objetivos próprios, os quais afetam o comportamento do conjunto como um todo. Qualquer ação de uma parte, necessariamente, provocará uma reação das demais (CHURCHMAN, 1975; MELO, 1987; ACKOFF apud ARAÚJO, 1994).

Um sistema possui entradas ou insumos (inputs), retira do ambiente o que necessita para poder operar (recursos, energia ou informação), processa suas entradas transformando-as (process), gera saídas ou resultados de suas operações na forma de produtos ou serviços (outputs), que são finalmente devolvidos ao ambiente (CHIAVENATO, 1994). Necessita retorno de parte de seus resultados (feedback), seja em forma de energia ou informação, para orientar-se em relação ao ambiente e aos desvios a serem corrigidos (Fig. 1).

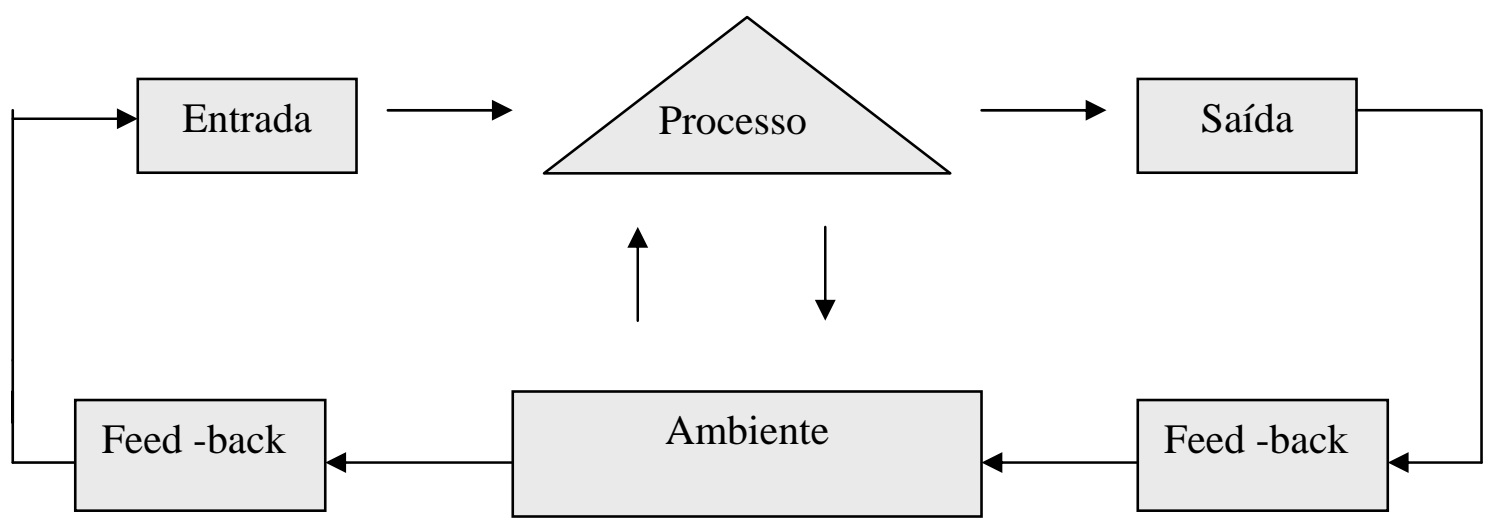

Fig. 1: Fluxo de Sistema 
A prática de medicação em uma organização hospitalar pode ser vista como um sistema, sendo definido como uma combinação de processos interdependentes que compartilham um objetivo comum (NADZAM, 1998).

Definir a prática de medicação como um sistema exige identificação de vários componentes necessários para realizar o propósito de fornecer tratamento medicamentoso ao paciente.

No sistema de medicação entendemos por insumo os pacientes e as informações a respeito da terapia medicamentosa; por processo, a realização de prescrição, dispensação e distribuição e administração de medicamentos; por resultado, os pacientes medicados com eficácia, e o tratamento seguro, como feedback, que realimenta o sistema, os relatórios e as informações geradas. Por último, temos como ambiente o conjunto de fatores e de condições que influencia a dinâmica desta prática (tecnologia, infra-estrutura, fornecedores, regras, regulamentos etc) fazendo com que o sistema se reajuste e se mantenha em contínua aprendizagem e auto-organização (NADZAM, 1998).

Em 1989, a Joint Commission on Accreditation of Healthcare Organizations - JCAHO identificou cinco componentes ou processos do sistema de medicação, quais sejam: seleção e obtenção do medicamento; prescrição; preparo e dispensação; administração de medicamentos e acompanhamento do paciente em relação aos efeitos do medicamento (NADZAM, 1998).

O sistema de medicação de um hospital é aberto e complexo, composto de vários processos em seu interior, desenvolvendo de 20 a 30 passos diferentes durante os processos de prescrição, dispensação e administração de medicamentos, envolvendo sempre muitos indivíduos e múltiplas transferências de pedidos ou 
materiais, que passam de uma mão à outra, que podem conduzir a erros na medicação (LEAPE et al., 2000). Estudo realizado por Leape et al. (1995) relata que 39\% dos erros na medicação ocorreram no processo de prescrição de medicamentos, $12 \%$ na transcrição, $11 \%$ no processo de dispensação e 38\% no de administração de medicamentos.

Além de inúmeros processos, o sistema utiliza-se de vários profissionais de saúde: enfermeira e sua equipe, médicos, farmacêuticos e a equipe da farmácia, o que lhe dá uma característica multidisciplinar.

Os médicos são os responsáveis pela prescrição de medicamentos, porém a maneira como ela é realizada varia de hospital para hospital. A equipe de enfermagem atua no último processo, que é o da administração do medicamento ao paciente, fato que faz com que muitos erros cometidos no início ou no meio do sistema, e não detectados, lhe sejam atribuídos.

Um dos problemas mais rapidamente percebidos durante os procedimentos desenvolvidos no sistema de medicação, na unidade hospitalar, é a falta de conscientização dos profissionais a respeito de sua posição dentro desse amplo sistema, e do qual fazem parte, pois suas ações interferem nas ações de outros profissionais e, conseqüentemente, no cuidado do paciente. É importante que o profissional que participa da medicação de um paciente conheça seu papel na corrente que se forma no desempenho das tarefas, para que desenvolva seu papel com segurança, consciência, responsabilidade e eficiência. Para que isso ocorra o sistema de medicação deve assegurar que os medicamentos sejam providos de maneira eficiente, responsável e transparente (LEE, 2002). 
As instituições hospitalares devem prevenir os erros na medicação através da elaboração e implementação de mecanismos de segurança voltados ao sistema de medicação, deixando de lado a perseguição e punição dos profissionais a cada erro ocorrido, fazendo com que este erro seja discutido e, assim, revertido em educação e melhorias para o sistema. Para tanto o sistema deve possuir alguns princípios e características considerados ideais, os quais funcionam como crenças fundamentais, sendo aplicáveis a todos os responsáveis por cuidados de saúde (LEE, 2002).

Os princípios ideais apregoam que o sistema deva centrar-se no paciente, basear-se no respeito aos outros e requerer o aceite à responsabilidade e à colaboração de todos os interessados, tanto dos profissionais envolvidos como do próprio paciente que também deve assumir responsabilidade de participar das decisões relativas ao seu tratamento.

Ainda segundo Lee (2002), o sistema de medicação deve conter as seguintes características ideais:

- Não sofrer descontinuidade em suas funções, processos, locações ou informações, funcionado sem solavancos e sem quaisquer óbvias interrupções na busca dos resultados desejados.

- Operar com o propósito de fluxo de processos lógicos, lançando mão da reengenharia para fazer o diagnóstico, procurando por pontos dentro do processo onde as conexões lógicas e os passos seguintes estão sendo interrompidos.

- Utilizar todos recursos na busca dos talentos lógicos para cada função, fazendo melhor uso da educação, treinamento e experiência profissional de seu pessoal.

- Ser o mesmo em todos os lugares. 
- Refletir uma consistente prática farmacêutica, pois as variações podem confundir o médico, a enfermeira e o paciente, favorecendo assim, os erros.

- Assegurar que todas as informações necessárias para prover o cuidado do paciente sejam fornecidas aos profissionais responsáveis.

- Ser seguro, do mesmo modo que a informação fornecida e trocada, a fim de garantir a confiança do paciente, constatada através do desempenho do sistema a cada passo crítico.

- Ser sensível ao tempo. Atrasos na administração de medicamentos ocorrem em todas as práticas, causados por problemas de comunicação ou pela necessidade do paciente ser tratado de uma outra maneira.

- Assegurar rígida responsabilidade aos profissionais e proporcionar verificação de desempenho de todos os passos críticos. Nesse caso, os relatórios são imprescindíveis, pois a descrição dos fatos poderá evitar confusão e melhorar a consistência de medidas.

- Ser antifalhas e operado com a filosofia de tolerância zero para erros, uma vez que a permissão de alguma porcentagem de erro criará desconfiança no sistema e complacência no desempenho.

Esta última característica citada por Lee (2002) é utópica, pois o sistema é basicamente operacionalizado por seres humanos e as falhas são inerentes a eles. Este último item descreve o ideal de qualidade a ser seguido na assistência à saúde, mas para ficarmos próximos desta meta precisaríamos estar constantemente atentos às medidas de segurança e de prevenção do próprio sistema.

Em um estudo multidisciplinar, após pesquisadores examinarem e revisarem minuciosamente o sistema de distribuição de quimioterápicos, estes utilizaram 
princípios de segurança e orientações que resultaram em melhorias para o sistema, reduzindo os erros que atingiam o paciente, como exposto a seguir: (WOMER et al., 2002):

1. Eliminar as punições para que os profissionais atuem sem medo de relatar seus erros;

2. Aprender com o erro aproveitando sua identificação e análise para promover mudanças e melhorias no sistema;

3. Preocupar-se com as saídas do sistema e não com as entradas;

4. Simplificar o sistema de medicação;

5. Padronizar os processos;

6. Utilizar procedimentos que estimulem as pessoas a seguirem o caminho certo;

7. Reduzir a transferência de atividades entre pessoas e/ou grupos de pessoas, diminuindo assim a possibilidade de erros;

8. Dar principal atenção ao fator humano.

Vários processos compõem o sistema de medicação, quais sejam: processo de prescrição, de transcrição, de distribuição ou dispensação, de preparação e de administração do medicamento. O número e tipo de processos podem variar de um hospital para outro, no entanto os profissionais baseiam-se em rituais profissionais e pessoais, conhecimentos técnicos e científicos, procedimentos e rotinas hospitalares e nas recomendações padronizadas pela instituição para executarem suas tarefas (CASSIANI, 1998).

Além da complexidade própria do sistema de medicação, os hospitais ligados às Universidades, que oferecem campo de estágio para escolas técnicas e que 
possuem acadêmicos e estudantes das diversas áreas da saúde atuando em suas instalações e prestando assistência a seus pacientes, devem considerar as situações inerentes àqueles que estão aprendendo, tais como: inabilidade, insegurança, falta de domínio técnico, limitada capacidade para interpretar e analisar as situações presentes e emergentes, precipitação, lentidão, apresentando, enfim, possibilidade maior de risco para a falha e para a iatrogenia do cuidado (MADALOSSO, 2000). Acrescenta-se ainda a esse processo o pouco conhecimento dos sistemas vigentes na instituição e seu papel dentro deles.

Este fato pode prejudicar a qualidade e a eficiência dos serviços prestados aos pacientes, principalmente no que se refere ao sistema de medicação que sempre comporta riscos, podendo, assim, causar danos à clientela.

Em vista disso, torna-se necessário conhecer o sistema de medicação utilizado nas instituições hospitalares e verificar como seus profissionais estão desenvolvendo suas atividades, se estas são preestabelecidas ou não por protocolos e padronizações, para permitirem identificação e análise das possíveis fragilidades e falhas ocorridas nos processos e intervir, minimizando riscos e aumentando a segurança do paciente.

A partir destas considerações é que foram traçados os objetivos deste estudo. 


\section{OBJETIVOS}

Pretende-se com este estudo atingir os seguintes objetivos:

- Descrever o sistema de medicação de um Hospital Universitário do estado de Goiás.

- $\quad$ Identificar e analisar as falhas nos processos e os erros na medicação a partir da opinião de uma amostra de profissionais envolvidos no sistema;

- $\quad$ Propor estratégias ao hospital visando melhorias para o sistema e para a segurança do paciente. 


\section{MATERIAL E MÉTODOS}

\subsection{TIPO DE ESTUDO}

Desenvolvemos um estudo do tipo survey exploratório na busca de coletar descrições detalhadas de variáveis existentes, utilizando os dados para justificar e avaliar condições e práticas em uso, como também para fazer novos planos visando melhorar essa prática. Os tipos de variáveis de interesse podem ser classificados como opiniões, atitudes ou fatos (LOBIONDO - WOOD, 2001).

Os estudos do tipo survey exploratório também são usados para buscar informações precisas sobre as características do sujeito de pesquisa, grupos, instituições ou situações ou ainda sobre a freqüência de ocorrências de um determinado fenômeno.

Segundo Polit \& Hungler (1999) o propósito do estudo exploratório é observar, descrever e documentar aspectos de uma situação ou a maneira como ela ocorre naturalmente.

\subsection{LOCAL DO ESTUDO}

A instituição estudada foi um hospital geral universitário, escolhido por ser campo de estágio para vários centros formadores de profissionais de saúde e o local onde esta pesquisadora atua como supervisora de alunos do Curso de Graduação em 
Enfermagem. Esta unidade está ligada à reitoria da universidade, sendo autônoma apenas para ordenação de despesas.

O referido hospital atende à população de toda região, tanto em procedimentos de alta complexidade, como em patologias incluídas no grupo de atenção primária e secundária. Como hospital de referência, atende não só a pacientes do estado de Goiás, mas também de outros estados, como Tocantins, Bahia, Pará, Mato Grosso, Acre, Rondônia e Distrito Federal. Presta serviços exclusivamente aos pacientes do Sistema Único de Saúde, o qual custeia as atividades do hospital e parte do pagamento do pessoal. Possui em torno de 315 leitos e quase 2000 mil funcionários, sendo que apenas 700 deles pertencem ao quadro permanente da universidade. Conta com duas enfermeiras nos cargos de Diretoria de Enfermagem e Administrativa.

A Diretoria de Enfermagem administra 667 profissionais, o que corresponde a 33,3\% do total de funcionários do hospital, sendo 131 (19,6\%) enfermeiros, 438 (65,7\%) técnicos de enfermagem e 98 (14,7\%) auxiliares de enfermagem. Pelos dados, percebemos que o hospital possui elevado número de técnicos de enfermagem, se comparado ao número de auxiliares de enfermagem.

Para obtenção dos dados, escolhemos dois setores dentro do hospital, quais sejam: a unidade de clínica médica e a farmácia hospitalar. Selecionamos a primeira por possuir, em média, 70 leitos distribuídos em 12 enfermarias com diversas especialidades, reservados a pacientes portadores de doenças crônico-degenerativas que, usualmente, fazem uso de grande e variada gama de medicamentos em seu tratamento. E a farmácia hospitalar, por ser a responsável pela aquisição, estocagem, conservação, controle, dispensação e distribuição dos medicamentos para todo o 
hospital. Ao estudarmos estes dois locais, tivemos como objetos de investigação: seu grupo de trabalho, suas rotinas e suas instalações.

A farmácia hospitalar é uma unidade técnica e administrativa dirigida por um profissional farmacêutico, cujo quadro de pessoal é formado por quatro farmacêuticos, sendo um deles o gerente e os três restantes recém-contratados pela instituição. Dois destes cumpriam carga horária de 40 horas semanais, no horário diurno, e o outro fazia horário especial de 6 horas, no período noturno. Contava ainda com 15 técnicos em farmácia, quatro auxiliares de farmácia, uma secretária, uma biomédica contratada como técnica de laboratório, que auxiliava na dispensação e preparo de quimioterápicos e nutrição parenteral total. No plantão noturno existiam alguns funcionários em desvio de função, sendo um estoquista e três auxiliares de nutrição. Não havia farmacêutico especificamente na unidade de clínica médica, assim como em nenhuma unidade de internação.

Quanto aos setores da farmácia responsáveis pelo fornecimento de medicamentos, estes são três: central de abastecimento de farmácia, setor de dose individualizada e a farmácia satélite do Pronto Socorro.

A farmácia em questão utilizava o sistema de distribuição de medicamento por dose individualizada para 24 horas, para as seguintes clínicas: Clínica Cirúrgica, UTI (Unidade de Terapia Intensiva) - Cirúrgica, Clínica de Medicina Tropical, Clínica Médica, UTI Médica, Ortopedia. Para as demais unidades, os medicamentos eram fornecidos por meio de estoque na própria unidade, ou seja, dose coletiva. Quanto à farmácia satélite no Pronto Socorro, que era uma extensão da farmácia hospitalar (central), ela tinha como finalidade conjugar o rápido acesso aos medicamentos e materiais com segurança e efetivo controle, atendendo à 
especificidade do setor, personalizando e agilizando ainda mais o atendimento de pontos críticos do hospital.

A unidade de clínica médica contava com 71 médicos, sendo 39 contratados e 32 residentes. Já a equipe de enfermagem desta unidade era constituída por 62 profissionais: um gerente de enfermagem, oito enfermeiros supervisores, quarenta e oito técnicos de enfermagem, quatro auxiliares de enfermagem e um auxiliar administrativo.

A divisão de trabalho da enfermagem era orientada pela enfermeira e seguia o método funcional, com distribuição de tarefas aos técnicos e auxiliares de enfermagem, em quatro frentes, quais sejam:

- Entregar materiais a serem utilizados no atendimento dos pacientes: pacotes de curativos, sondagens, hemoglicoteste, material para punção venosa, aparelhos de pressão etc. Esta atividade era desenvolvida por um funcionário em cada plantão, escalado mensalmente, e realizada no posto de procedimentos (PP), que ficava na metade do corredor da clínica; este também agia como interlocutor entre o funcionário do posto de medicação e os demais profissionais.

- Efetuar requisições, conferir e acondicionar os medicamentos provenientes da farmácia, além de preparar todos os medicamentos a serem administrados pelos profissionais de enfermagem responsáveis pelos cuidados dos pacientes internados. Esta atividade era desenvolvida por um funcionário em cada plantão, escalado mensalmente, e realizada no posto de medicação (PM), situado no fundo do posto de procedimento, sem contato com o corredor da unidade. 
- Realizar os curativos. Atividade desempenhada por um funcionário em cada plantão, escalado mensalmente, que realizava exclusivamente todos os curativos dos pacientes da clínica.

- Prestar cuidados gerais aos pacientes, com exceção dos curativos, e administrar os medicamentos que já vinham preparados e identificados do posto de medicação. Desenvolviam esta atividade de seis a oito funcionários escalados por plantão, distribuídos em 12 enfermarias, tendo cada uma seis leitos em média. A escala era diária, havendo constante rodízio entre funcionários e enfermarias.

\subsection{POPULAÇÃO E AMOSTRA}

A população em estudo constituiu-se dos profissionais que pertenciam ao quadro de pessoal da unidade de clínica médica e da farmácia hospitalar, que desempenhavam funções relacionadas à medicação dos pacientes internados nesta unidade, quais sejam: 16 médicos residentes, 8 enfermeiros supervisores, 48 técnicos de enfermagem, 4 auxiliares de enfermagem, 4 farmacêuticos e 15 técnicos de farmácia totalizando 95 profissionais atuantes no período de coleta dos dados (setembro a dezembro de 2002). Os prontuários de todos os pacientes da clínica médica também foram utilizados.

A amostra, após realizada a coleta de dados, constituiu-se de: 01 profissional farmacêutico, responsável pelo sistema de medicação e designado pela instituição; 12 médicos residentes, 4 enfermeiras supervisoras, 14 técnicos de enfermagem, 2 auxiliares de enfermagem, 3 farmacêuticos e 5 técnicos de farmácia, que estavam atuando no período da coleta de dados. 
Ainda foram analisamos 294 prontuários médicos dos pacientes hospitalizados na clínica médica.

\subsection{PROCEDIMENTO DE COLETA DE DADOS}

Realizamos a coleta dos dados nos meses de setembro a dezembro de 2002, tendo como foco o sistema de administração de medicamentos da unidade de internação de clínica médica.

4.4.1. Etapas, técnicas e procedimentos para coleta de dados.

O estudo desenvolveu-se em quatro etapas, sendo que para cada uma correspondeu determinada técnica de coleta de dados, a saber: entrevistas; observação não-participante e análise de prontuários e papeletas.

\section{Primeira Etapa de Coleta}

Realizamos uma entrevista estruturada seguindo um roteiro que permitiu ao pesquisador aplicar um questionário, adaptado de Hatfield (1999), com perguntas abertas, fechadas e diretas (APÊNDICE A). Entrevistamos inicialmente o profissional responsável pelo sistema de medicação, designado pelo Diretor do Hospital, com intuito de obter uma visão geral do sistema vigente, sendo o mesmo farmacêutico e, na época da coleta, assumia o cargo de gerente da Farmácia.

A pesquisadora agendou uma entrevista com esse profissional com o objetivo de conhecer o sistema de medicação vigente no hospital, sob a perspectiva deste. 


\section{Segunda Etapa da Coleta}

Realizamos observações não-participantes e diretas, durante três semanas, no período de 6 de outubro a 4 de novembro, tendo como alvo os profissionais e acadêmicos que participavam do sistema de medicação da unidade de clínica médica do hospital em questão, quais sejam: médicos residentes e acadêmicos responsáveis pela prescrição de medicamentos; os profissionais da farmácia responsáveis pela separação, dispensação e distribuição dos medicamentos e os profissionais da enfermagem responsáveis pelo acondicionamento, preparo e administração de medicamentos, pelo monitoramento e registro dos medicamentos administrados, assim como por qualquer outra intercorrência que pudesse ocorrer nesse procedimento.

A observação não-participante e direta obedeceu ao método de coleta de dados em que o observador não oculta sua participação e posição de observador, revelando sua identidade e obtendo consentimento informado do sujeito da pesquisa para ser observado. O observador, neste caso, não intervém tentando provocar ou mudar o comportamento do sujeito participante (LO BIONDO-WOOD, 2001).

Na coleta dos dados, três auxiliares de pesquisa observaram concomitantemente os três processos do sistema de medicação, dedicando uma semana para cada processo, durante sete dias consecutivos, observando três dias no plantão da manhã (domingos, segundas e terças), dois dias no plantão da tarde (quartas e quintas) e dois dias no plantão noturno (sextas e sábados). Quanto aos horários, estes foram: no período da manhã: das 8 às 12 h; tarde das 14 às 18 h e noite das 19 às 23 h. As observações seguiram um roteiro estruturado (APÊNDICE B) que continha nome do observador; datas; horários de início e término da 
observação; local e processo observado para descrição das atividades, problemas e falhas observadas. Este roteiro foi desenvolvido durante a realização do projeto multicêntrico mencionado na apresentação (CASSIANI et al., 2003).

A amostragem foi por conveniência, considerando-se que a escolha dos sujeitos foi baseada no maior número de atividades a serem executadas nos horários e locais predefinidos.

Na primeira semana, os auxiliares de pesquisa permaneceram na unidade de clínica médica observando os médicos residentes e acadêmicos do $5^{\circ}$ ano de medicina, assim como o ambiente à sua volta, durante a prescrição de medicamentos e o encaminhamento destas à farmácia.

Na segunda semana, permaneceram na farmácia hospitalar observando os farmacêuticos, técnicos de farmácia e auxiliares de farmácia que realizavam a dispensação e distribuição dos medicamentos, assim como examinaram o ambiente onde se desenrolava o fluxo de chegada das prescrições, separação, dispensação de medicamentos e distribuição dos mesmos para a unidade de clínica médica.

$\mathrm{Na}$ terceira semana, observaram as atividades dos profissionais de enfermagem na clínica médica, o posto de medicação e as enfermarias, durante o recebimento dos medicamentos, acondicionamento dos mesmos nas caselas dos respectivos pacientes, preparo dos medicamentos, administração, monitoramento e registro.

O objetivo desta etapa foi identificar e analisar as situações em que ocorreram falhas nos diversos procedimentos realizados durante os processos de medicar. 


\section{Terceira Etapa de Coleta}

Realizamos entrevistas semi-estruturadas com os profissionais e residentes de medicina que desempenhavam funções ligadas à medicação na unidade de clínica médica e na farmácia hospitalar, durante o período de 4 de novembro a 7 de dezembro (APÊNDICE C). Fizemos várias visitas nestas unidades, durante os três turnos de trabalho, com intuito de entrevistar 100\% dos profissionais (equipe de enfermagem, equipe de farmácia, e médicos residentes) atuantes na medicação.

Para conhecer o quadro funcional da clínica médica obtivemos uma listagem com os nomes dos funcionários da clínica, da farmácia e dos médicos residentes que atuavam na clínica, excluindo os que estavam de férias, licença ou ausentes no dia e horário agendados para a entrevista.

Gravamos as entrevistas em fita cassete, após autorização do entrevistado, para facilitar a análise posterior.

O objetivo desta etapa foi obter opiniões sobre os tipos de erros mais freqüentes, causas da ocorrência desses erros, providências tomadas, falhas do sistema e sugestões para prevenção dos erros na medicação.

\section{Quarta Etapa de Coleta}

Fizemos a revisão de todos os prontuários médicos de pacientes internados no período da coleta de dados na clínica médica, buscando informações contidas nas prescrições de medicamentos, nas evoluções médicas, nas anotações e relatórios de enfermagem do dia anterior ao da coleta de dados, referentes à ocorrência de eventos adversos ao medicamento. Para tal, utilizamos um roteiro estruturado (APÊNDICE D), durante sete dias consecutivos, de 30 de novembro a 6 de dezembro, com o 
objetivo de identificar inadequações nas prescrições médicas, como ilegibilidade, ausência de dados, uso de abreviaturas, alterações, rasuras etc; existência de anotações de enfermagem e relatórios de ocorrências referentes a reações adversas, a erros na medicação ou a problemas relacionadas ao uso de medicamentos.

Vale ressaltar que este roteiro também foi desenvolvido e utilizado no projeto multicêntrico do qual este estudo fez parte (CASSIANI et al., 2003).

\subsubsection{Treinamento dos auxiliares de pesquisa}

Para executar a função de auxiliar de pesquisa, selecionamos enfermeiras (os), porém, devido à indisponibilidade de tempo dos profissionais face à escala rígida de horários em determinados períodos, optamos por incluir também acadêmicos do último ano do curso de graduação em enfermagem. Capacitamos quatro auxiliares de pesquisa, para o caso de substituição, porém somente três participaram do estudo.

O treinamento dos auxiliares teve como objetivo orientá-los quanto à maneira de se identificarem no momento da coleta, a não interferirem nos procedimentos durante as observações, a manterem uma postura ética, a abordarem os entrevistados e como redigirem os relatórios com as observações.

O treinamento teve uma carga horária de 20 horas, onde desenvolvemos atividades teórico-práticas, utilizando as seguintes bibliografias: CASSIANI (2000b); LEAPE et al. (1995) e FLYNN et al. (2002).

O módulo teórico forneceu noções sobre erros no sistema de medicação, desenvolvidas através de leitura de textos e artigos, discussão e elucidação do 
projeto, esclarecimentos sobre as diversas etapas de coletas de dados, instrumentos utilizados e orientação a respeito da observação não-participante.

O módulo prático forneceu aos auxiliares de pesquisa treinamento da atividade de observação, no qual utilizamos materiais audiovisuais, como TV e videocassete. Este treinamento serviu também para avaliarmos se os auxiliares estavam aptos a realizarem a coleta dos dados, através do método da observação. Para tanto, solicitamos que apresentassem um relatório escrito das situações observadas no vídeo e verificamos se as constantes do relatório atendiam aos dez itens da descrição da situação prática apresentada no APÊNDICE E. Os três auxiliares de pesquisa assistiram juntos ao mesmo filme e fizeram seus relatórios ao mesmo tempo. Consideramos aptos aqueles auxiliares de pesquisa cujas observações atendiam a $80 \%$ dos itens.

\section{5. ÉTICA NA PESQUISA}

O projeto de pesquisa foi encaminhado às Diretorias das Faculdades de Enfermagem, Farmácia e Medicina e Diretorias do Hospital, da Clínica Médica, da Enfermagem e Gerência da Farmácia para análise e aprovação. A seguir, encaminhamos o mesmo para o Comitê de Ética em Pesquisa Médica e Humana e Animal do hospital em questão, que concedeu parecer positivo para a realização da pesquisa (ANEXO A).

Os gerentes das unidades envolvidas foram comunicados pelos seus superiores da presença dos pesquisadores e do início da coleta dos dados. 
Na ocasião, os profissionais e acadêmicos envolvidos receberam explicação sobre o tema, objetivo e finalidade da pesquisa. Também os consultamos quanto à sua disponibilidade para participação na pesquisa, garantindo-lhes anonimato. A seguir, solicitamos sua assinatura no termo de consentimento livre e esclarecido (APÊNDICE F), conforme as normas vigentes (BRASIL, 1996).

O desenvolvimento da pesquisa em questão não ofereceu riscos ou desconforto aos participantes ou à instituição.

\subsection{ORGANIZAÇÃO E ANÁLISE DOS DADOS}

Após o término de cada etapa da coleta, iniciamos a análise dos dados, conforme descrito a seguir:

a) Na etapa 1 , digitamos os dados obtidos, os quais lemos e analisamos segundo as características do sistema e dos processos, sendo os mesmos apresentados em forma descritiva.

b) Nas etapas 2 e 3, também digitamos os dados obtidos, e após lê-los, os categorizamos e os analisamos, sendo os mesmos apresentados em tabelas contendo freqüências absolutas e relativas.

c) Na etapa 4, após digitarmos os dados obtidos, os organizamos em tabelas contendo freqüências absolutas e relativas. 


\section{RESULTADOS}

Os dados obtidos nas quatro etapas da coleta de dados permitiram que identificássemos o funcionamento do sistema de medicação e dos demais processos inerentes a ele, assim como as falhas e problemas ocorridos nos mesmos. Possibilitaram também que conhecêssemos as opiniões dos profissionais envolvidos nesse trabalho, sobre o sistema e sobre os erros ocorridos na medicação. Portanto, inicialmente, apresentaremos o sistema de medicação e, a seguir, a análise do mesmo, detectando as falhas e os problemas constatados em seus processos.

\subsection{APRESENTAÇÃO DO SISTEMA DE MEDICAÇÃO}

Os dados mostram que o sistema de medicação do hospital estudado inicia-se com a prescrição manual de medicamentos, feita em duas vias, sendo a cópia enviada à farmácia por um mensageiro. Quanto à dispensação e distribuição de medicamentos, realizadas pela farmácia hospitalar, estas são processadas em doses individualizadas para 24 horas e distribuídas às clínicas. Todos os medicamentos são preparados por um ou dois profissionais da enfermagem, em um posto de medicação, e administrados pela equipe de enfermagem alocada nas enfermarias.

Apresentaremos este sistema detalhadamente por meio de um fluxograma construído com o propósito de reunir informações sobre os processos de medicação e as etapas percorridas, seguido da descrição das atividades desenvolvidas com base nas rotinas e procedimentos estabelecidos pelo hospital e pela clínica médica, quais 
sejam: prescrição, dispensação, distribuição, preparo e administração dos medicamentos.

Os gráficos de fluxo ou de processo, denominados de fluxogramas, procuram representar, de maneira dinâmica e analítica, a seqüência lógica das fases, etapas ou passos de um trabalho desenvolvido, por meio de determinadas simbologias. Este recurso tem como finalidade evidenciar a seqüência lógica de um trabalho, promovendo condições de se realizar uma análise com o intuito de melhorar o método (ROCHA, 1987). Para Araújo (1994), fluxograma é a técnica mais conhecida e mais utilizada para os estudos de rotinas administrativas, uma vez que procura apresentar a rotina passo a passo, ação por ação.

A construção do fluxograma, neste estudo, auxiliou o pesquisador a analisar o sistema e seus processos através da identificação de falhas, problemas e inadequações, possibilitando, também, a proposição de medidas que visassem à otimização do processo, à prevenção de erros e à melhoria da qualidade do atendimento.

Apresentamos a seguir desenhos de 14 fluxos, utilizando simbologias que propiciam uma visão ampla das etapas percorridas pelo medicamento até que este chegue ao paciente (Fig. 2).

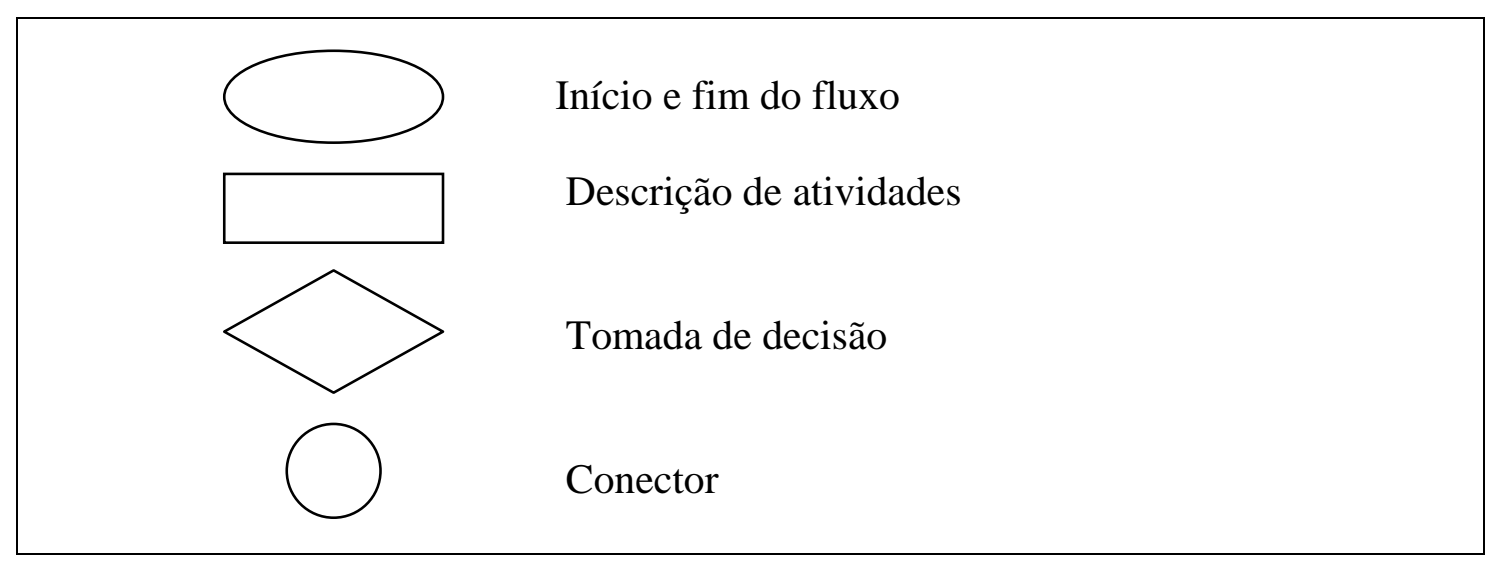

Fig. 2: Simbologias do fluxograma 
Fluxo 1- Prescrição de medicamentos - Médico

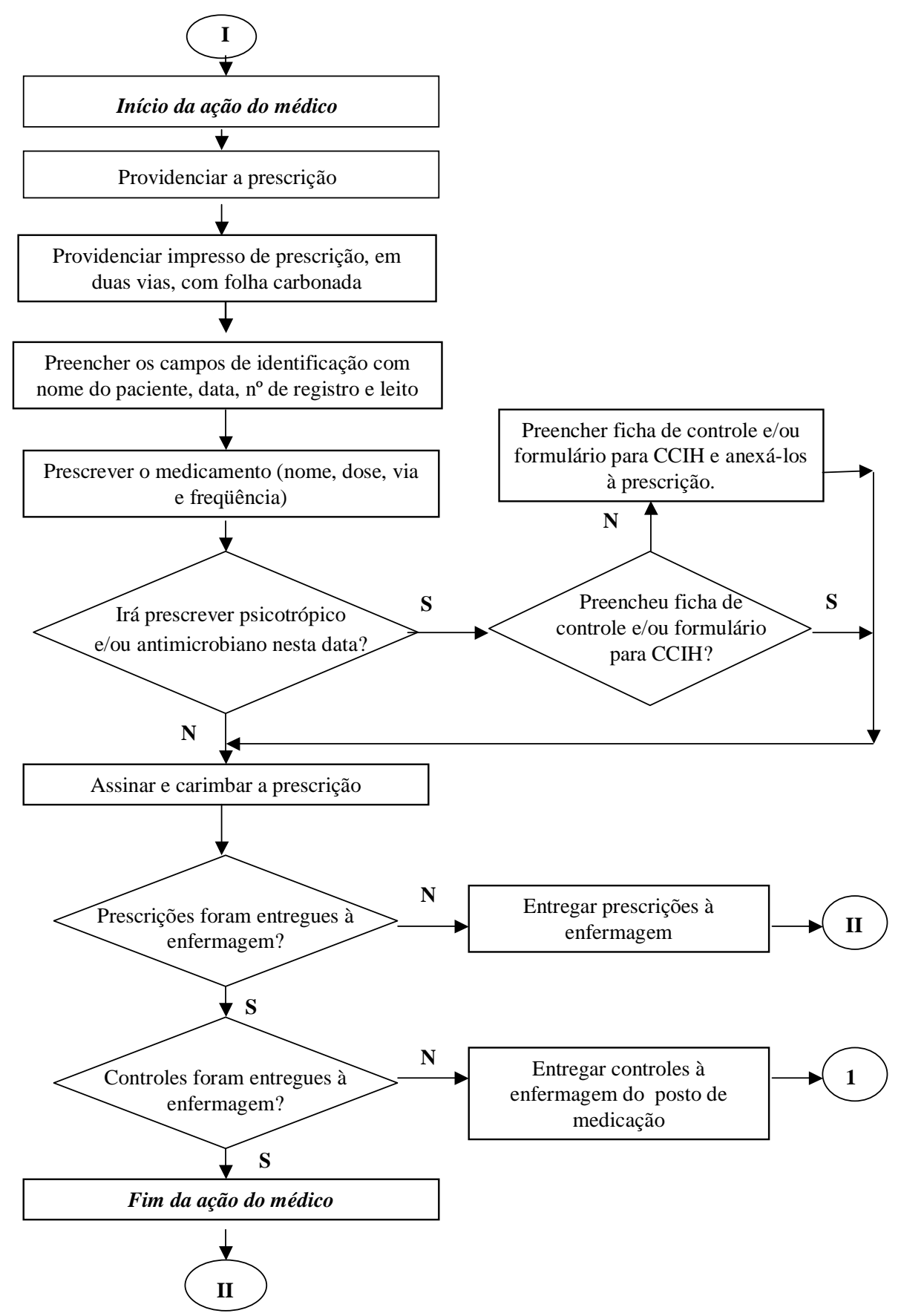

As atividades de rotina desempenhadas pelos médicos, nesse processo (Fluxo 1), são:

1. Providenciar a papeleta do paciente. 
2. Providenciar o impresso específico para prescrição, contendo folha de carbono.

3. Preencher os campos de identificação com os dados do paciente e a data.

4. Prescrever os medicamentos: copiar a prescrição do dia anterior, fazendo as alterações necessárias, excluindo ou incluindo medicamentos ou alterando dosagens.

5. Em caso de primeira prescrição ou reinício de antibióticos: preencher formulário da CCIH (Comissão de Controle de Infecção Hospitalar) solicitando liberação para uso e fornecimento do mesmo, de acordo com o tempo desejado de uso.

6. Anexar o formulário à prescrição

7. Em caso de prescrição de psicotrópicos: preencher um formulário padronizado de controle.

8. Anexar o formulário à prescrição.

9. Assinar e carimbar a folha de prescrição (na maioria das vezes, os profissionais fazem isso apenas na primeira via).

10. Deixar as papeletas sobre os balcões do corredor do posto de enfermagem, ou nas enfermarias, para que a enfermagem faça os encaminhamentos necessários para que os medicamentos sejam providenciados. 
Fluxo 2- Encaminhamento das prescrições de medicamentos -

Equipe de enfermagem

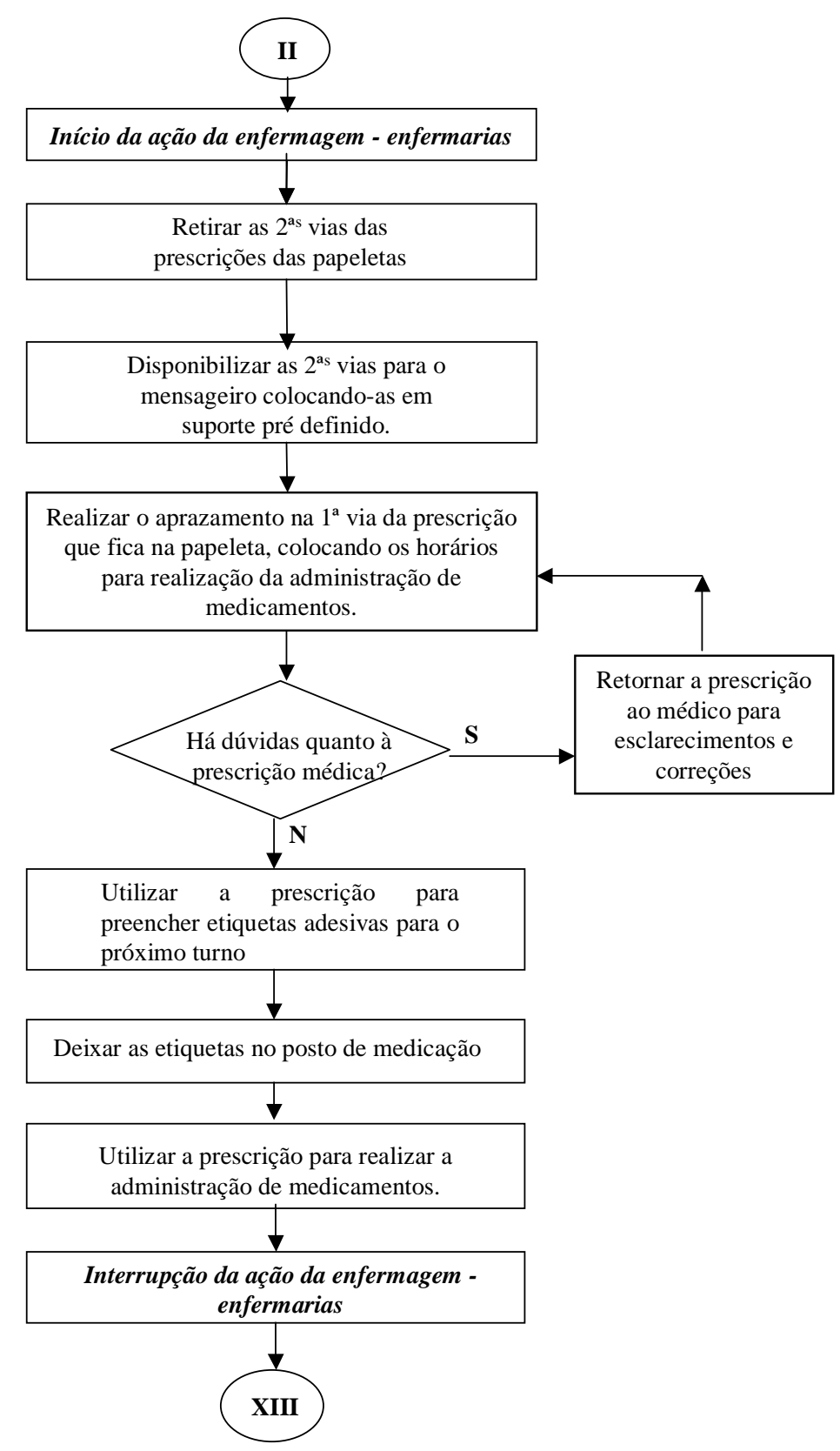


Fluxo 3- Encaminhamento da requisição de psicotrópico e antimicrobiano Equipe de enfermagem

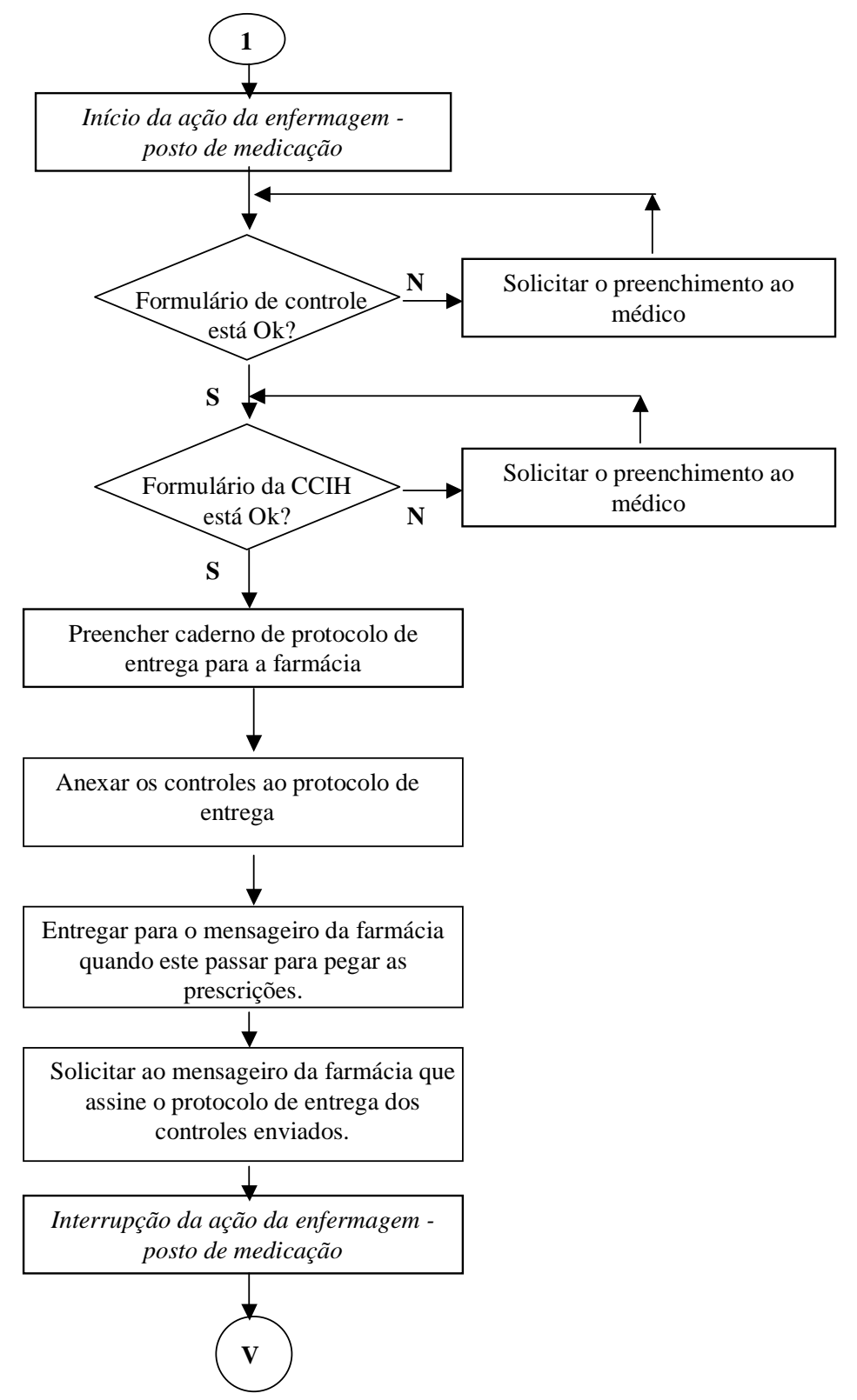

As atividades de rotina desempenhadas pela equipe de enfermagem, responsável pelas enfermarias e posto de medicação, relacionadas à prescrição de medicamentos e ao seu encaminhamento (Fluxos 2, 3), são: 
1. Retirar a $2^{\mathrm{a}}$ via da prescrição.

2. Disponibilizar a $2^{\mathrm{a}}$ via para o mensageiro da farmácia, colocando-a em local predeterminado.

3. Deixar a $1^{\mathrm{a}}$ via na papeleta do paciente para que sejam feitos os aprazamentos, as conferências, checagens e anotações pertinentes.

4. Fazer o aprazamento na $1^{\mathrm{a}}$ via - cada equipe preenche o horário correspondente ao seu turno de trabalho.

5. Utilizar a prescrição para copiar os medicamentos prescritos, em etiquetas adesivas, que serão utilizadas pelo profissional de enfermagem, responsável pelo posto de medicação, para separação, preparo e identificação dos medicamentos e entregá-las no posto de medicação.

6. Utilizar a prescrição para o preparo e administração de medicamentos.

7. Pegar os formulários de controle de antibióticos e psicotrópicos e verificar se foram preenchidos de forma correta.

8. Registrar os formulários de controle que serão enviados, em caderno de protocolo, para que o mensageiro da farmácia o assine ao pegar os formulários. 
Fluxo 4- Encaminhamento da prescrição de medicamentos à farmácia Equipe da farmácia

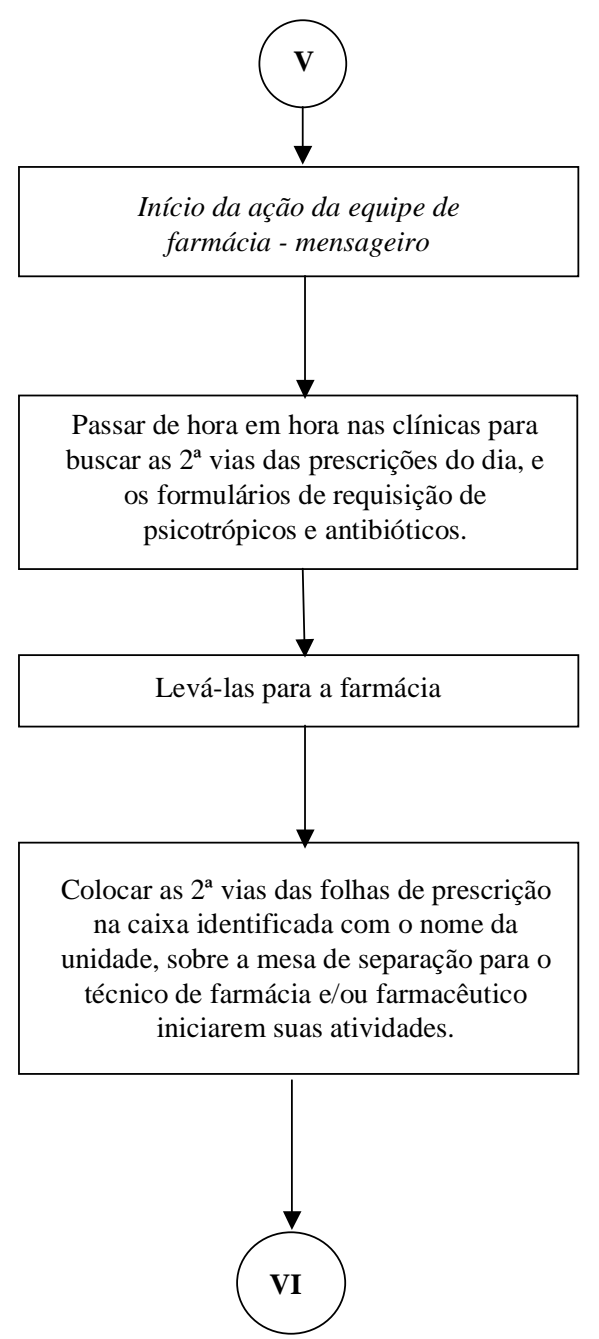




\section{Fluxo 5 - Dispensação e distribuição dos medicamentos}

\section{Equipe de farmácia}

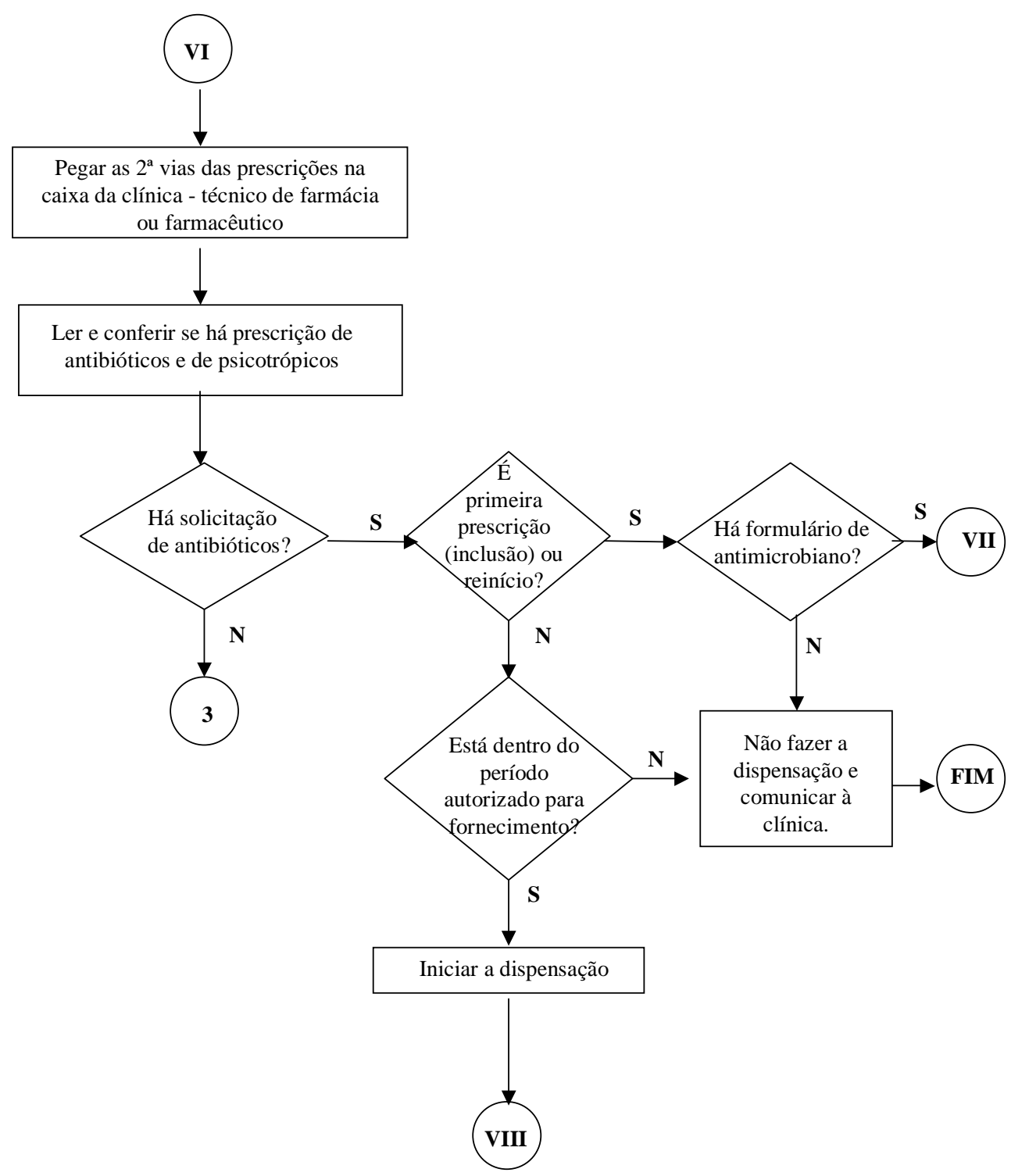




\section{Fluxo 6 - Dispensação e distribuição dos medicamentos}

\section{Equipe de farmácia}

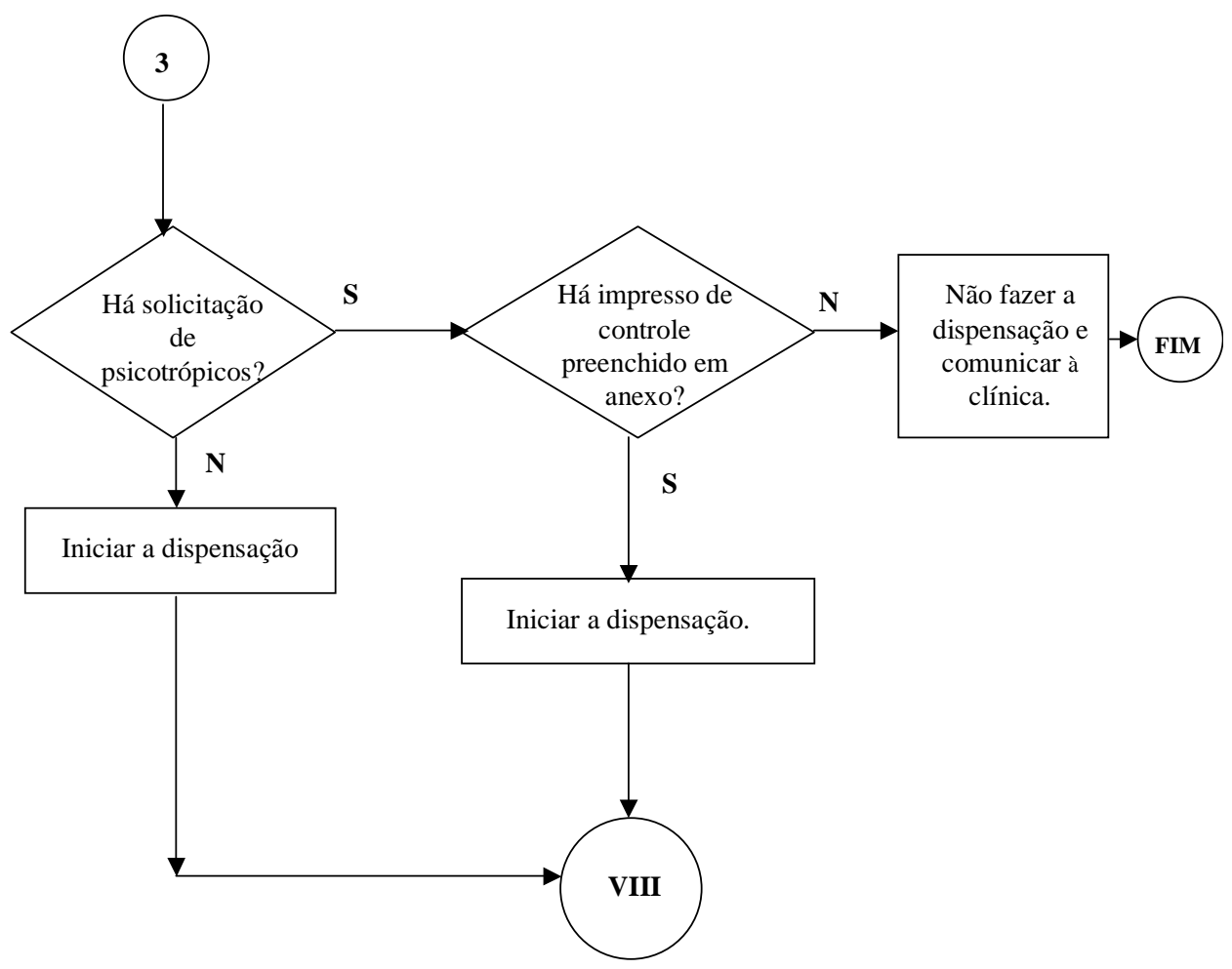


Fluxo 7 - Dispensação e encaminhamentos das requisições de antimicrobianos para CCIH

Equipe de farmácia

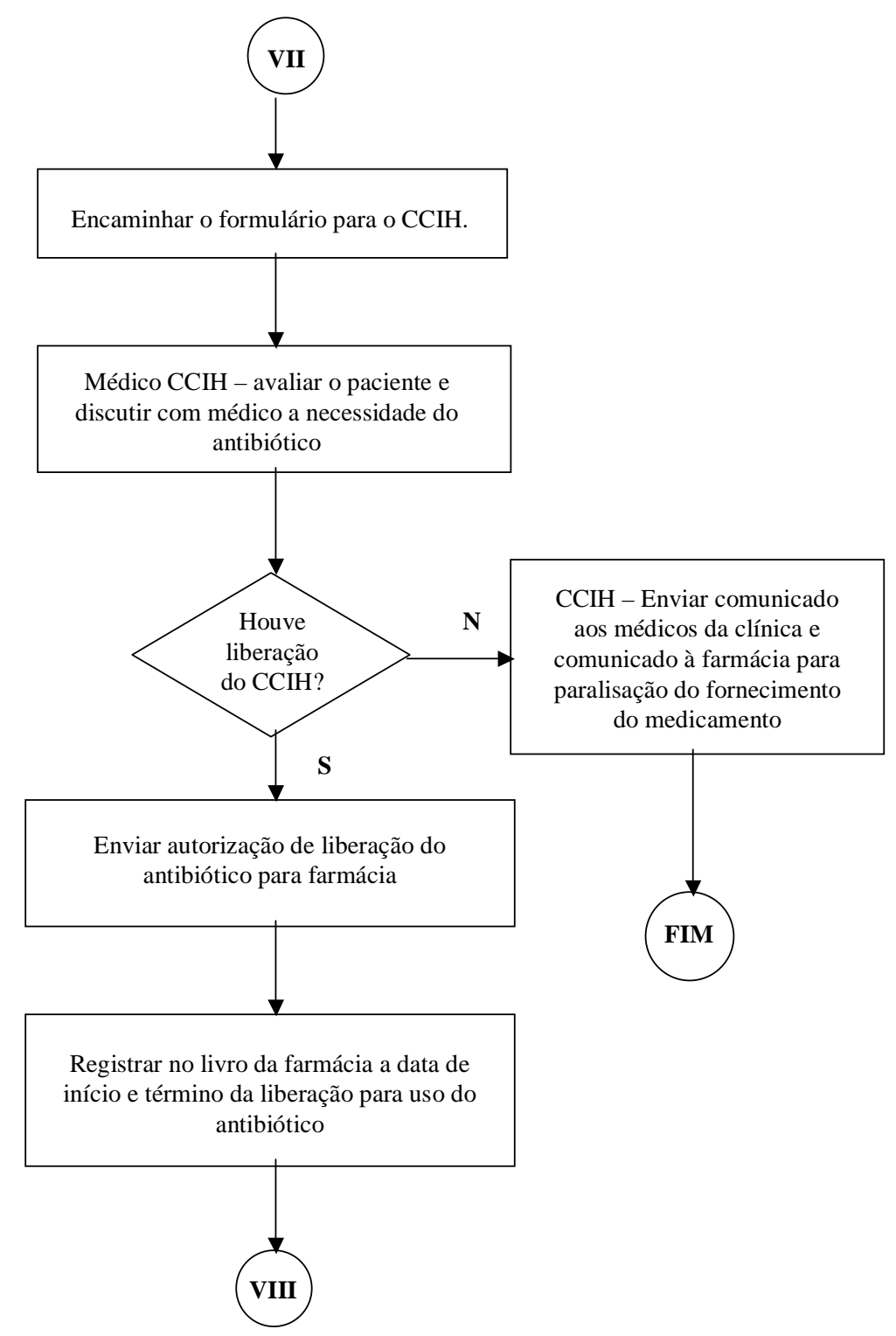


Fluxo 8- Dispensação e distribuição dos medicamentos

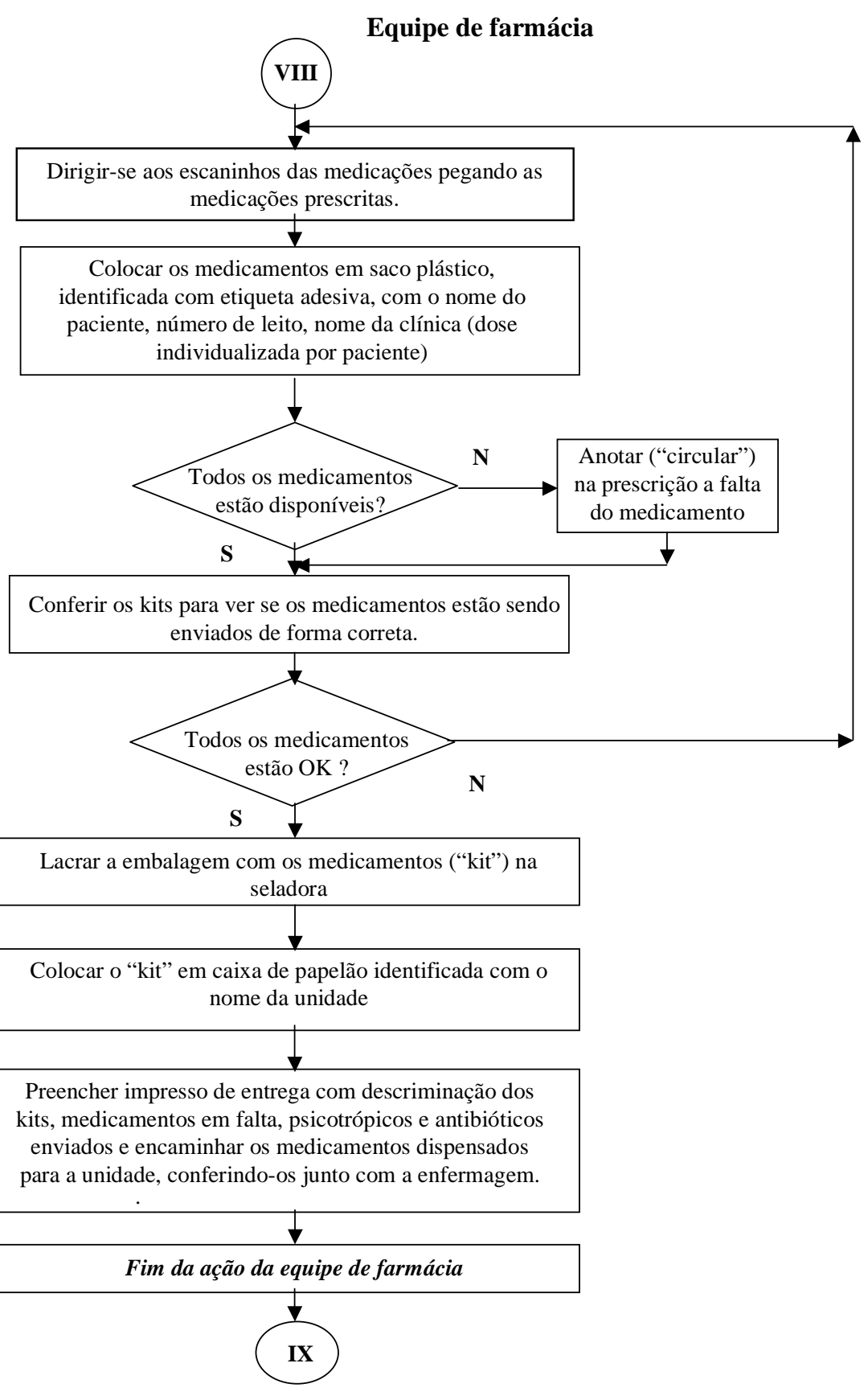

As atividades desempenhadas pela equipe da farmácia, relacionadas à dispensação e distribuição dos medicamentos (Fluxos 4, 5, 6, 7, 8), são as seguintes: 
1. O mensageiro deve passar na clínica médica de hora em hora, a partir das oito horas, para realizar o recolhimento das $2^{\text {as }}$ vias das prescrições, os formulários de solicitação de psicotrópicos e antibióticos e assinar o livro de protocolo .

2. Levar as $2^{\text {as }}$ vias das prescrições para a farmácia.

3. Colocar as prescrições em caixa sobre a mesa de separação, na sala de dose individualizada da farmácia.

4. O técnico de farmácia deve começar a dispensação dos medicamentos, após a preparação dos kits, conforme as prescrições vão chegando (exceto em casos de emergência).

5. Ler e conferir as prescrições.

6. Fazer um rótulo (etiqueta adesiva), manualmente, com nome do paciente, número de leito e nome da clínica que deverá ser colado no saco plástico onde os medicamentos serão colocados.

7. Dirigir-se aos armários compartimentalizados (tipo escaninho) e pegar os medicamentos. Os compartimentos são etiquetados com nome comercial, genérico, código do medicamento e dosagem, e organizados em ordem alfabética do nome genérico.

8. Colocar os medicamentos de cada prescrição em saco plástico, denominado "kit de medicamento".

9. Verificar se há prescrição de antibióticos ou formulário preenchido a ser enviado e aprovado pela CCIH.

10. Enviar formulário para avaliação da CCIH. Quando a avaliação demora mais de dois dias, o farmacêutico libera o antibiótico. Se a CCIH não liberá-lo, encaminhar-se-á um comunicado por escrito ao médico solicitante. 
11. Conferir se a autorização do antibiótico está dentro da data estipulada para uso; caso contrário, o antibiótico não será fornecido.

12. Em caso de antibiótico em suspensão, calcular para quantas doses e quantos dias será suficiente um frasco para atender o tratamento. Anotar em caderno de controle para que não seja fornecido novo frasco antes do término do primeiro.

13. Conferir se o formulário de controle de psicotrópico foi enviado e se está preenchido de forma correta; caso contrário, o medicamento não será fornecido.

14. Acondicionar os psicotrópicos e antibióticos solicitados corretamente em sacos plásticos separados.

15. Preparar as quimioterapias e as nutrições parenterais em câmeras de fluxo laminar (farmacêutico).

16. Conferir se todos os medicamentos prescritos estão sendo enviados e de maneira correta e fechar o saco plástico na seladora.

17. Colocar um “ok” na prescrição já atendida e separá-la para não misturar.

18. Colocar o "kit” em caixa de papelão identificado com o nome da clínica.

19. Preencher impresso de controle de entrega, discriminando os kits que serão entregues, os medicamentos em falta e os psicotrópicos e antibióticos que estão sendo enviados.

20. Levar os medicamentos para clínica médica por volta de 14 e 15h, conferí-los juntamente com o profissional de enfermagem e solicitar assinatura de recebimento. Os solicitados na urgência são entregues logo que dispensados. 
Fluxo 9 - Recebimento dos medicamentos na unidade de internação

Equipe de enfermagem

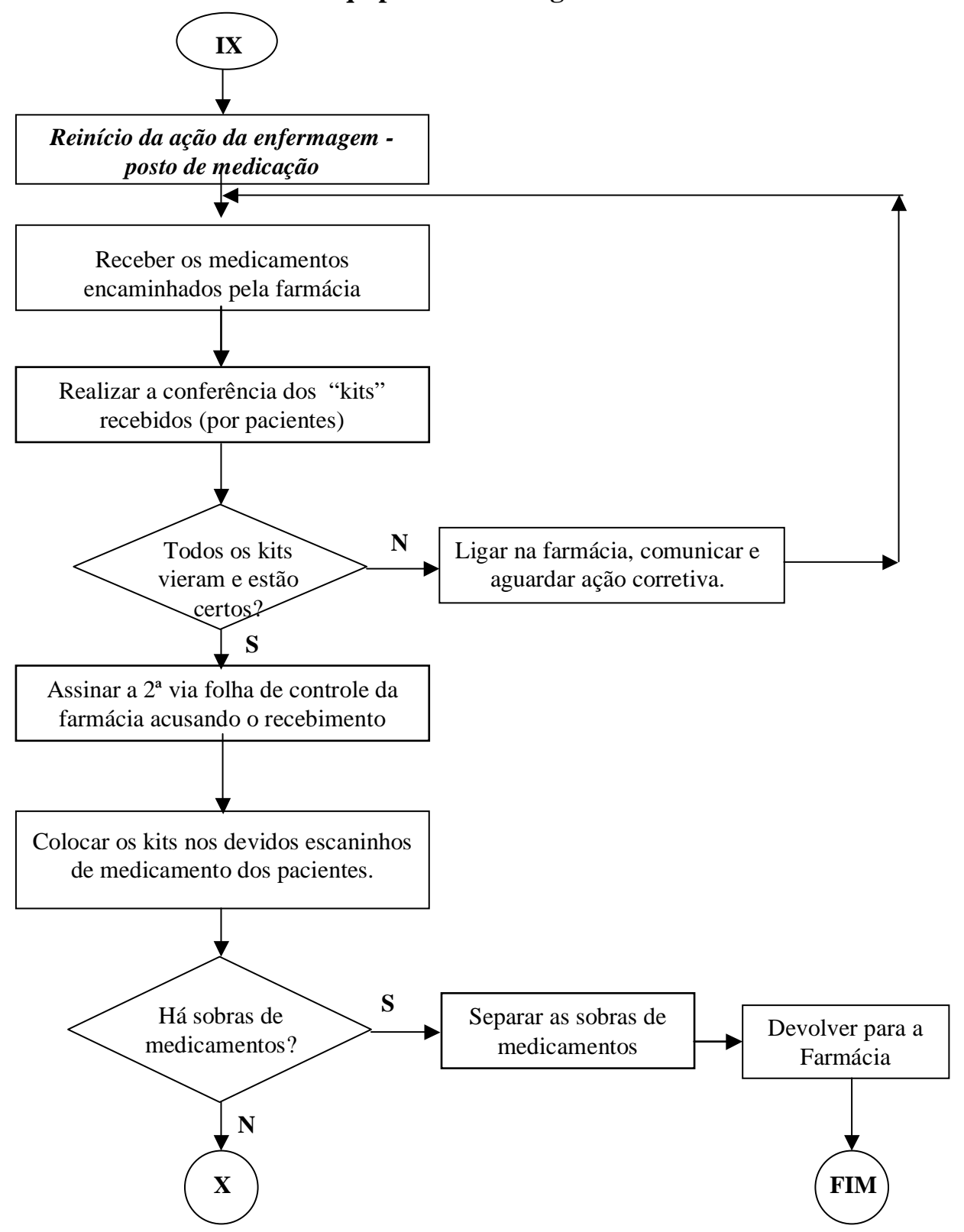




\section{Fluxo 10- Preparo de medicamentos}

\section{Equipe de enfermagem}

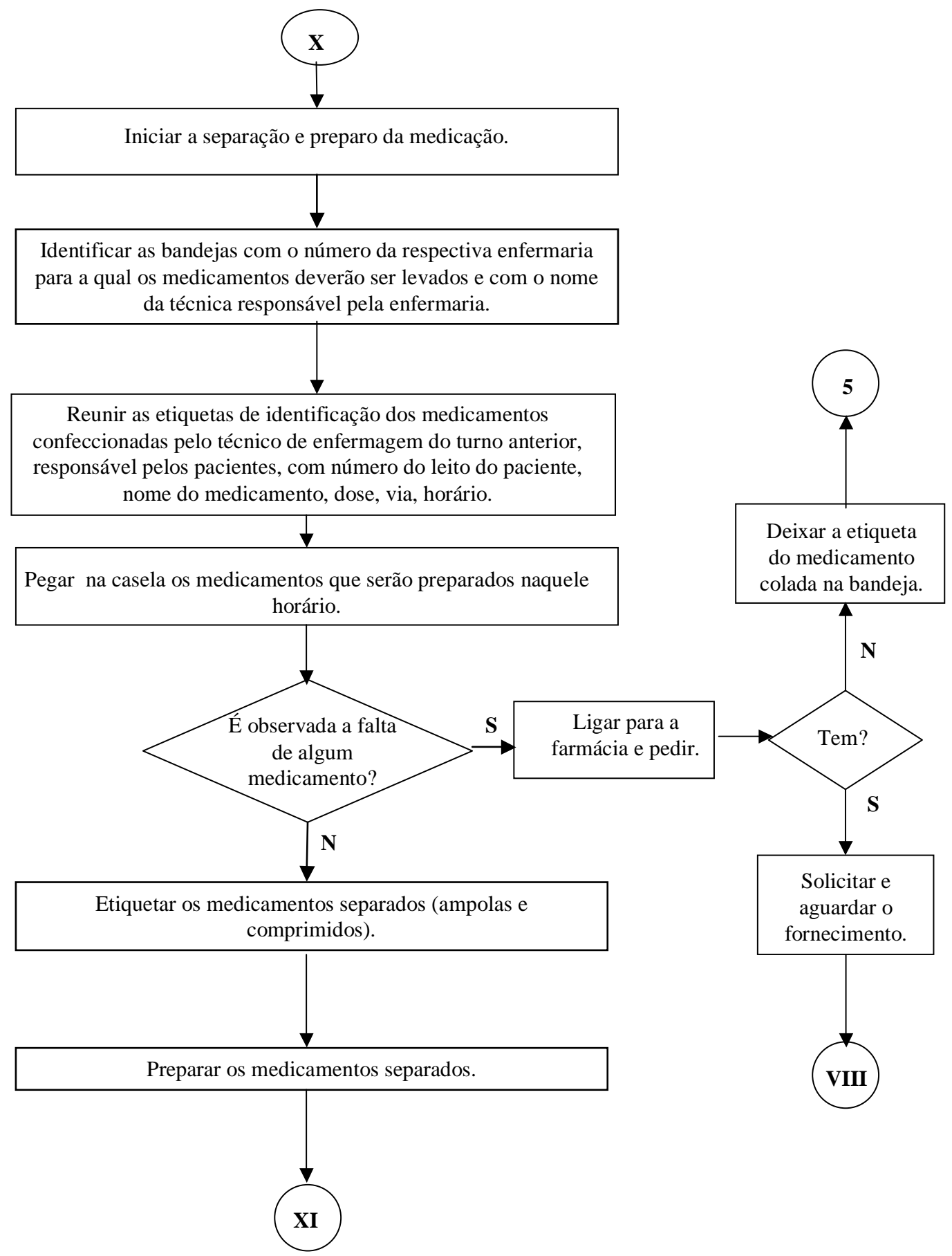




\section{Fluxo 11- Preparo de medicamentos}

\section{Equipe de enfermagem}

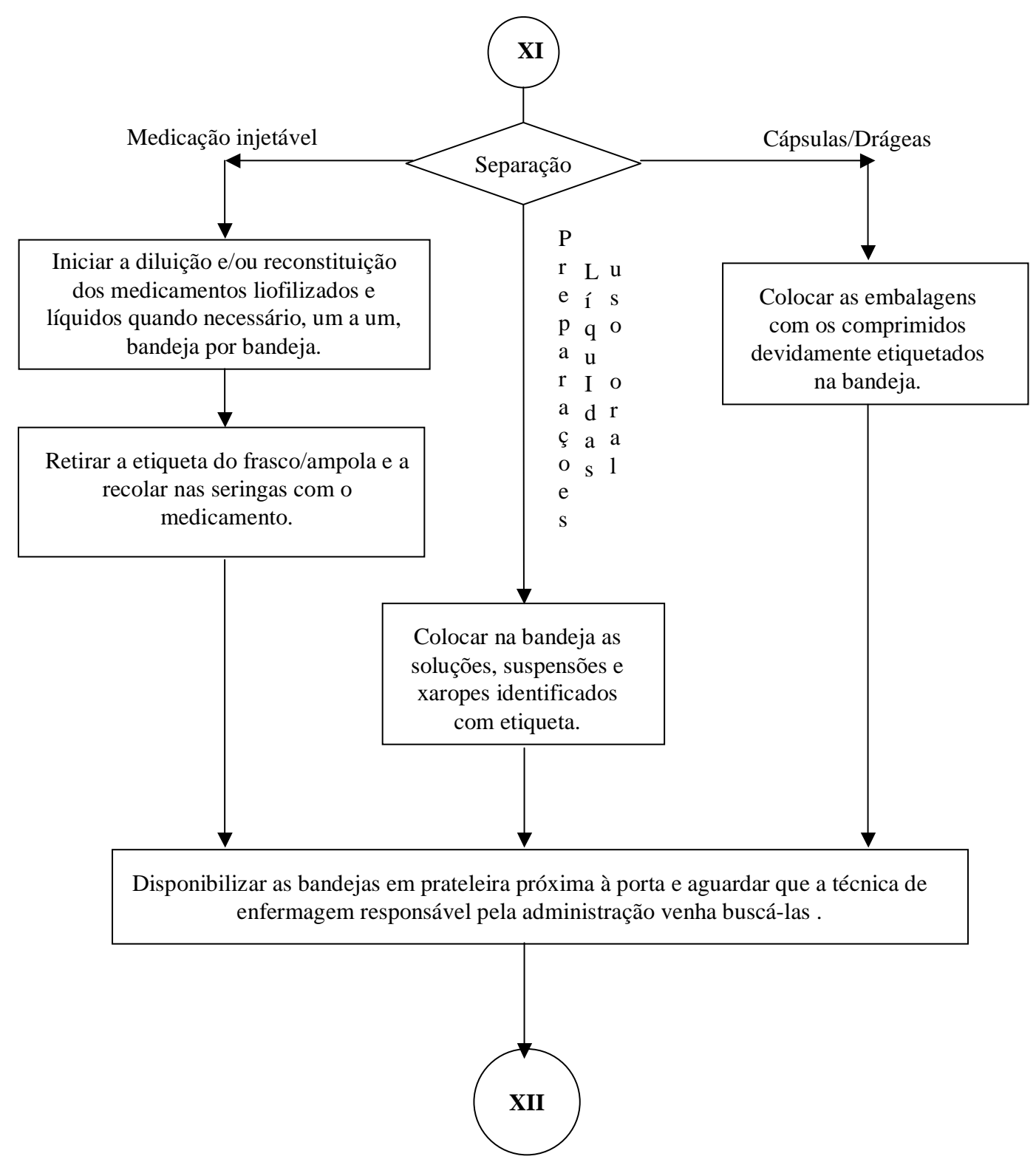




\section{Fluxo 12- Preparo de medicamentos}

\section{Equipe de enfermagem}

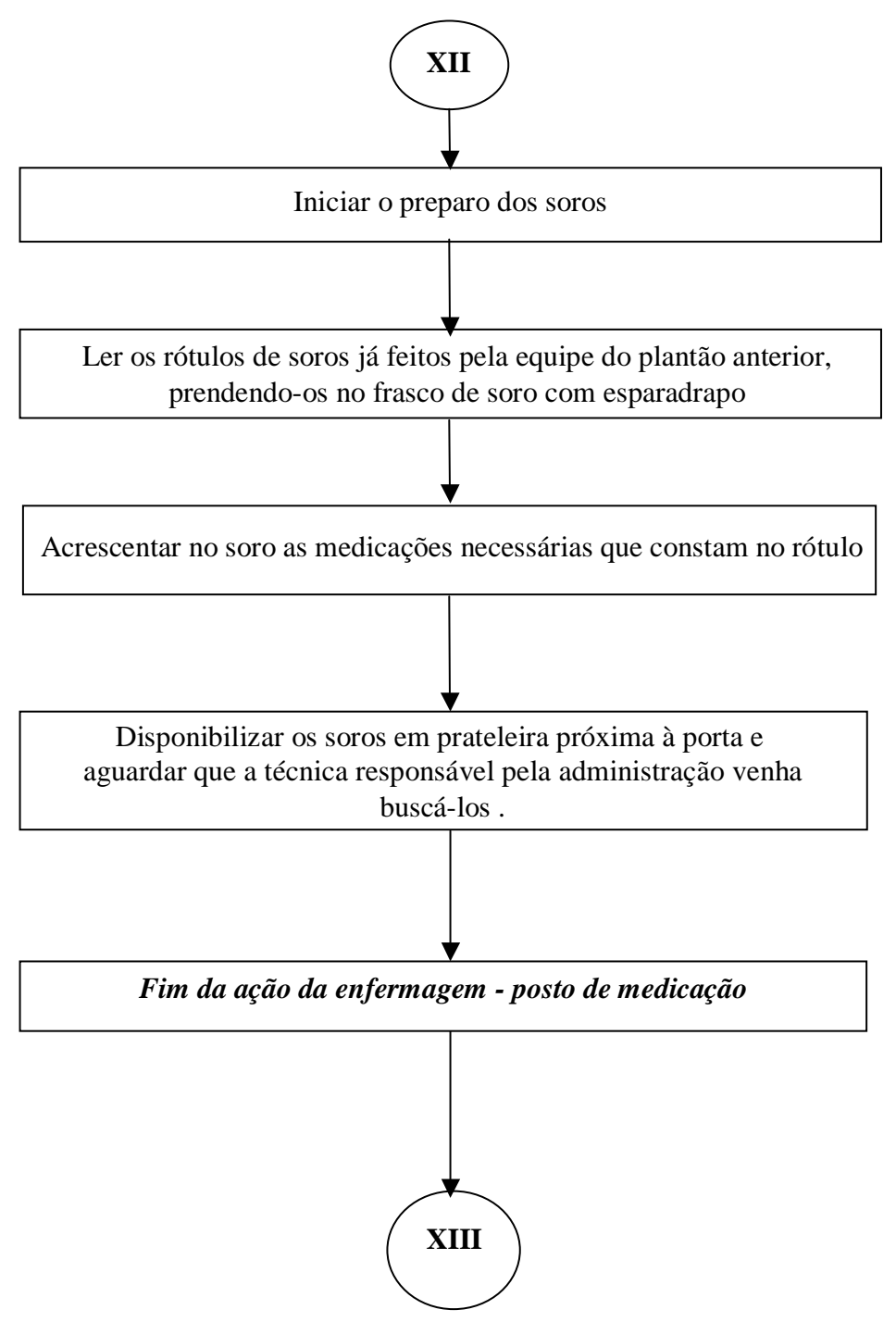


Fluxo 13- Administração de medicamentos

Equipe de enfermagem

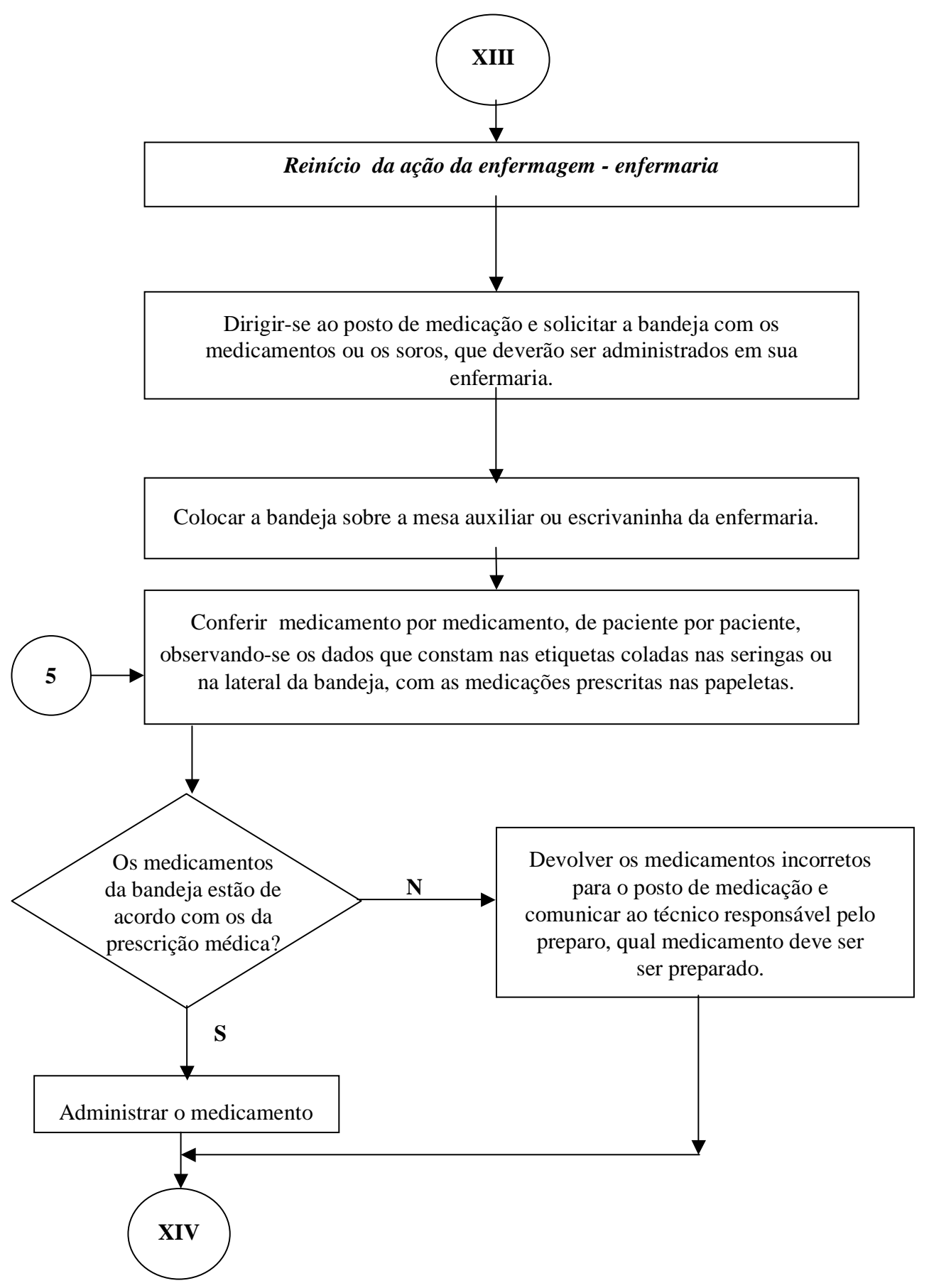


Fluxo 14- Administração de medicamentos

Equipe de enfermagem

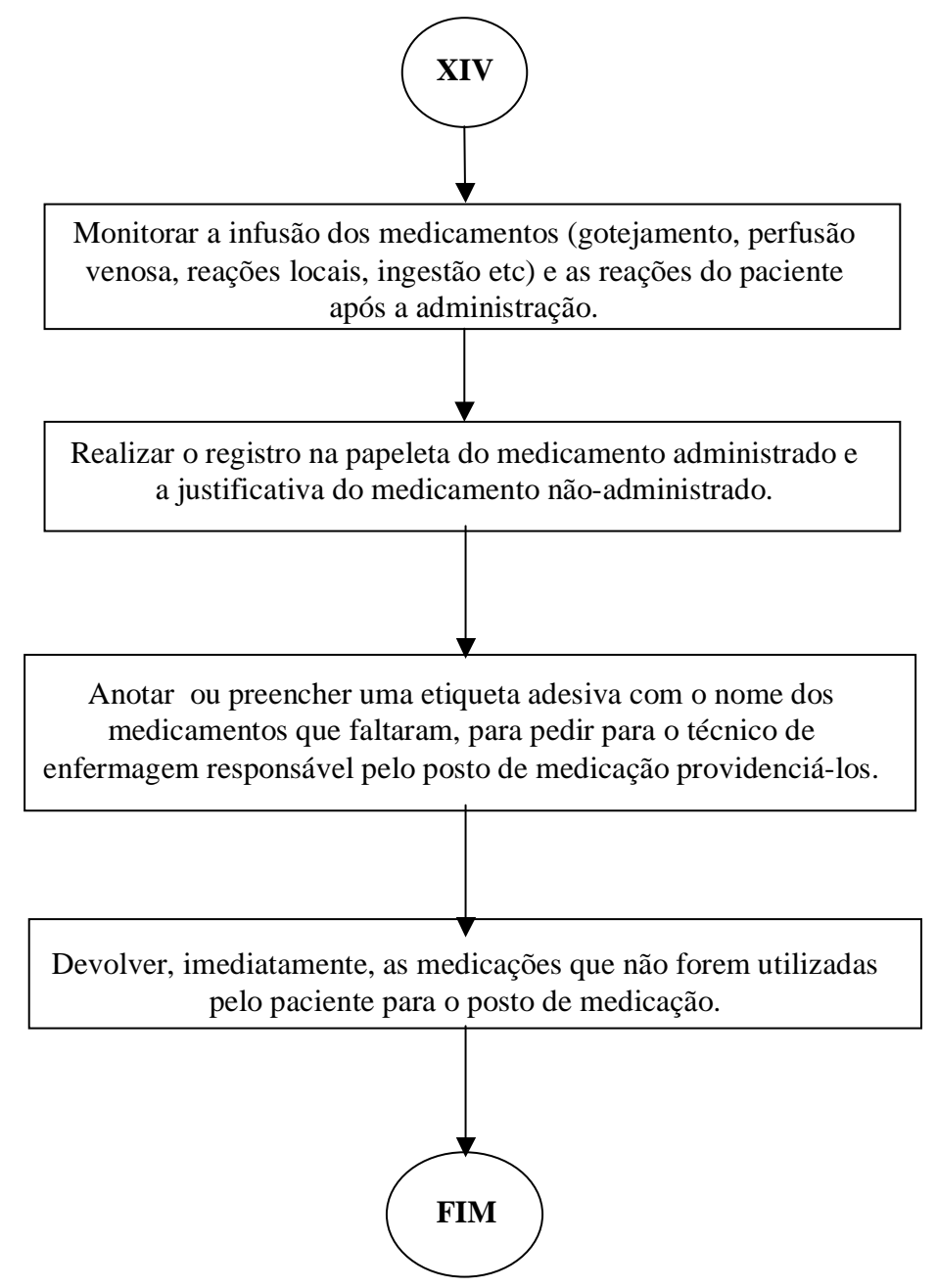

As atividades desempenhadas pela equipe de enfermagem, responsável pelas enfermarias e posto de medicação, na preparação e administração de medicamentos (Fluxos 9, 10, 11 ,12, 13, 14), são: 
1. Receber os medicamentos da farmácia e conferir, junto com o mensageiro da farmácia, todos os "kits” enviados, olhando o nome do paciente e número do leito, e guardá-los nas caselas.

2. Assinar o impresso de recebimento, somente dos antibióticos e psicotrópicos.

3. Iniciar o preparo de todos os medicamentos do plantão, por volta de 2 horas antes do horário de administração.

4. Separar e enumerar as bandejas de acordo com as enfermarias, colocando nelas o nome da técnica de enfermagem escalada na enfermaria (às vezes em uma única bandeja são acondicionados medicamentos de 02 enfermarias).

5. Ler o rótulo (etiqueta adesiva) já preparado pelo plantão anterior com os números dos leitos dos pacientes, nomes, doses, horários e vias dos medicamentos prescritos e pegar os medicamentos nas caselas.

6. Iniciar a diluição e reconstituição dos medicamentos, um a um, bandeja por bandeja.

7. Tirar a etiqueta do frasco/ampola e colá-la nas seringas com o medicamento já diluído.

8. Meia hora antes do horário de administração, colocar as bandejas em uma prateleira próxima à porta do posto de procedimentos para serem liberadas para as enfermarias.

9. Iniciar o preparo dos soros.

10. Ler os rótulos de soros já feitos pela equipe do plantão anterior, prendendo-os no frasco de soro com esparadrapo.

11. Colocar os soros próximos à porta do Posto de Procedimentos para que a técnica responsável pela medicação das enfermarias venha buscá-los. 
12. Seguir a rotina estabelecida pela clínica quanto aos horários de administração dos medicamentos.

13. Buscar as bandejas com medicamentos e soros no Posto de Procedimentos (PP).

14. Colocar a bandeja com medicamentos sobre a mesa auxiliar da enfermaria e conferir um a um, com base nos dados das etiquetas coladas nas seringas, e nas prescrições, fazendo um ponto com a caneta ao lado dos medicamentos corretos.

15. Conferir todos os medicamentos, colar as embalagens com os comprimidos na papeleta, utilizando para isso as etiquetas, e colocar as seringas com medicamentos diluídos sobre a respectiva papeleta.

16. Iniciar a administração

17. Monitorar a infusão dos medicamentos (gotejamento, perfusão venosa, reações locais, ingestão etc) e as reações do paciente após a administração.

18. Comunicar-se com o paciente. A maioria das técnicas de enfermagem chama o paciente pelo nome, mas não esclarece qual o remédio e qual sua função.

19. Checar os medicamentos na prescrição $\operatorname{com} u m(\checkmark)$.

20. Fazer um círculo no horário e colocar ao lado "NT", quando o medicamento não for administrado por estar em falta na farmácia.

21. Caso falte medicamento, pedir providências fazendo anotação em um papel de rascunho ou preenchendo uma etiqueta adesiva.

22. Devolver medicamentos não utilizados para o posto de medicação. 
A análise do fluxograma indicou que os profissionais executam 60 atividades desde o processo de prescrição de medicamentos até o seu registro, das quais 10 são realizadas pela equipe médica durante o processo de prescrição, 20 pela equipe de farmácia e 30 pela equipe de enfermagem.

O fluxograma também permitiu a visualização geral do sistema e reuniu informações sobre cada um dos processos, de maneira que pudemos identificar problemas, para os quais poderão ser projetadas mudanças e melhorias para a segurança do paciente.

A seguir analisaremos as falhas e os problemas referentes aos três processos de medicação, conforme os dados obtidos.

\subsection{ANÁLISE DO SISTEMA DE MEDICAÇÃO QUANTO A FALHAS E} PROBLEMAS DETECTADOS NOS PROCESSOS.

Os dados obtidos na entrevista com o profissional responsável pelo sistema, nas observações não-participantes e na revisão dos prontuários médicos foram analisados conjuntamente, a fim de que o pesquisador identificasse as falhas ou problemas nos processos de medicação.

Categorizamos os dados provenientes das observações a partir do projeto multicêntrico já apresentado (CASSIANI et al., 2003), sendo elas relacionadas da seguinte forma:

Problemas referentes a:

1. Conhecimento sobre medicamento: situações em que as falhas denotaram conhecimento inadequado, insuficiente ou inexistente, relativos aos 
medicamentos, tais como: uso, dose, vias, preparação e administração de medicamentos.

2. Prescrição de medicamentos: situações em que se detectaram falhas na redação da prescrição, tais como grafia ilegível, rasura, falta de assinatura etc ou na própria prescrição, como posologia, via ou prescrição incompleta.

3. Solicitação e requisição: situações em que as falhas eram decorrentes de problemas relacionados à solicitação e requisição de medicamentos à farmácia, tais como: falta de formulários, preenchimento incorreto, não-preenchimento de impressos, não-encaminhamento.

4. Dispensação e estoque da medicação: situações em que se detectaram falhas na dispensação e estoque de medicamentos.

5. Preparação dos medicamentos: situações em que as falhas ocorreram no preparo do medicamento, executado de forma incorreta e inadequada (horário, local, pessoal).

6. Administração de medicamentos propriamente dita: situações em que se detectaram falhas na técnica de administração, no registro e na relação com o paciente.

7. Monitoramento: situações em que ocorreram falhas no controle e monitoramento da medicação do paciente, tais como gotejamento, tempo de infusão, verificação da perfusão venosa, da ingestão do comprimido etc e nas reações do paciente ao medicamento.

8. Checagem dos medicamentos: situações em que se detectaram falhas na conferência e anotação do medicamento (farmácia e enfermagem). 
9. Informação sobre o paciente: situações em que as falhas eram decorrentes de desconhecimento do profissional sobre algum aspecto importante do paciente, relacionado à utilização de medicamentos.

10. Violação de regras: situações em que as falhas ocorreram por não seguirem procedimentos estabelecidos para a assistência segura do paciente (horário da medicação, redação incompleta da prescrição, preparo sem prescrição).

11. Ambiente: situações em que falhas ocorreram devido a interferências do ambiente na prescrição, dispensação, preparo e administração dos medicamentos, tais como ambiente com ruído, desorganização, inadequação quanto à iluminação, ventilação, circulação de pessoas.

12. Interação com outros serviços: situações em que se detectaram falhas com outros serviços e profissionais.

13. Outras falhas não incluídas acima.

Realizamos a análise do sistema de medicação com base nos processos de medicação: prescrição, dispensação, distribuição e administração de medicamentos.

5.2.1 Falhas ou problemas detectados no processo de prescrição de medicamentos

O processo de prescrição de medicamentos, no hospital em questão, é realizado manualmente em duas vias, utilizando-se papel carbono. As prescrições podem conter medicamentos com nomes genéricos ou comerciais, abreviaturas, porém os dados do paciente (idade, peso, altura) podem estar ou não disponíveis e atualizados, dependendo da rotina da clínica. 
A seguir, apresentaremos na Tabela 1, as freqüências dos relatos de situações obtidas nas observações e identificadas como falhas ou problemas e as categorias da prescrição de medicamentos. 
TABELA 1 - Problemas identificados no processo de prescrição de medicamentos do sistema de medicação de um Hospital Universitário de Goiás, segundo categoria, descrição e freqüência de relatos. Goiânia, 2002

\section{CATEGORIA}

Ambiente

\section{DESCRIÇÃO DO PROBLEMA}

1. Problemas relacionados a interrupções para conversas e telefones.

2. Problemas relacionados a distrações e $\quad 4 \quad 17,4$ conversas.

3. Problemas referentes a outras características do ambiente (abafado, sem ventilação, pequeno para muitas pessoas).

4. Problemas relacionados a ruído.

5. Problemas relacionados à organização do local.

\begin{tabular}{cc}
\multicolumn{2}{c}{ RELATOS } \\
\hline $\mathrm{N} \quad \%$ \\
\hline
\end{tabular}

$3 \quad 13,0$

$2 \quad 8,7$

14,4

Subtotal

1575,0

Problemas na

prescrição de

medicamentos

1. Uso de abreviaturas não padronizadas

315,0

Subtotal

$3 \quad 15,0$

Problemas relacionados

1. Falta de informação e comunicação para a clínica sobre medicamentos em falta na $\quad 2 \quad \mathbf{1 0 , 0}$

à dispensação e estoque

farmácia.

de medicamentos

Subtotal

$2 \quad 10,0$

Total de relatos

$20 \quad 100$

A Tabela 1 indica que o ambiente apareceu em 15 (75,0\%) relatos como problema predominante nas prescrições de medicamentos, sejam por interrupções, distrações ou conversas observadas durante o processo de prescrever.

O uso de abreviaturas, permitido nesse hospital, foi citado em 3 (15\%) relatos.

Na análise dos prontuários médicos de pacientes hospitalizados na unidade de clínica médica também identificamos falhas e problemas no processo de prescrição de medicamentos, conforme mostra a Tabela 2. 
TABELA 2 - Número e freqüência das características atribuídas às prescrições de medicamentos analisadas na unidade de clínica médica de um Hospital Universitário de Goiás. Goiânia, 2002

\begin{tabular}{lcc}
\hline CARACTERÍSTICAS & Total & $\mathbf{\%}$ \\
DAS PRESCRIÇÕES DE MEDICAMENTOS & $\mathbf{2 9 4}$ & $\mathbf{1 0 0}$ \\
\hline Legibilidade da grafia médica & & \\
& & \\
Legível & 190 & 64,6 \\
Não legível & 20 & 6,8 \\
Em parte & 82 & 27,9 \\
Não assinalada & 2 & 0,7 \\
\hline Idemtifição do paciente
\end{tabular}

Identificação do paciente ou médico na prescrição

Completa

Incompleta*

- Falta do nome e/ou CRM legível do médico

111

46,9

- Falta do nome completo e legível do paciente

27

37,8

Medicamentos prescritos com nome

9,2

Comercial

Princípio ativo

$110 \quad 37,4$

Ambos

0

183

0

Não assinalado

1

62,2

Preenchimento dos dados dos medicamentos

Completo

Incompleto *

- Falta apresentação

- Falta forma de diluição

- Falta de dose

- Falta via de administração

- Falta freqüência

7,1

\section{Uso de abreviaturas}

Sim

Não

\section{Alterações dos medicamentos}

Sim

Não

Itens não assinalados 1,4

Rasuras na prescrição de medicamentos

\begin{tabular}{lcc} 
Sim & 88 & 29,9 \\
Não & 204 & 69,4 \\
Item não assinalado & 2 & 0,7 \\
\hline
\end{tabular}

* Há mais de uma alternativa para esta questão 
A Tabela 2 mostra que, apesar dos problemas de grafia apresentados na prescrição manual, do total de 294 prescrições analisadas, 190 (64,6\%) estavam legíveis, porém vale ressaltar o risco de erro na medicação em 102 (34,7\%) estando estas ilegíveis ou legíveis em parte.

No que se refere à identificação do paciente ou do médico, nas folhas de prescrição analisadas observamos que, 111 (37,8\%) delas não continham o nome completo e legível do médico ou o número de registro no Conselho Regional de Medicina (CRM), tendo 25 destas apresentado somente o nome do acadêmico de medicina ( $5^{\circ}$ ano), que ainda não podia ser o responsável pela terapia medicamentosa. Quanto ao nome do paciente, este não apareceu legível ou correto em 27 (9,2\%) prescrições analisadas. As alergias são geralmente questionadas pela enfermagem e anotadas na admissão do paciente, entretanto, nem sempre esta anotação é encontrada nos prontuários, segundo informações do responsável pelo sistema.

A Tabela 2 mostra ainda a predominância da prescrição de medicamentos com nomes comerciais. Em 110 (37,4\%) prescrições, encontramos apenas nomes comerciais e em 183 (62,2\%), os médicos utilizaram ora o nome comercial ora o genérico, o que é ainda pior, pois pode levar a erros de dispensação ou administração.

No que concerne ao preenchimento dos dados dos medicamentos, a Tabela 2 indica que 279 (94,9\%) das prescrições estavam incompletas para um item ou mais, sendo que em 228 (77,6\%) faltavam a forma de apresentação dos medicamentos e em 111 (37,8\%) não constavam a forma de diluição para o uso; itens necessários para a correta dispensação e administração dos medicamentos. 
As abreviaturas são permitidas pelo sistema e tanto a equipe médica, como a de farmácia e de enfermagem fazem uso da maioria delas, no entanto, $13 \%$ dos entrevistados as consideraram problemas. Elas foram encontradas em 282 (95,9\%) prescrições sendo as mais encontradas: VO (via oral) em 185 (62,9\%); EV (endovenoso) em 136 (62,9\%); cp (comprimido) em 75 (46,2\%). Em relação à abreviatura "cp", devemos salientar que ela foi interpretada pelas auxiliares de pesquisa ora como comprimido ora como cápsula, não havendo concordância de compreensão a respeito da informação transmitida pelo prescritor.

A Tabela 2 informa ainda que 63 (21,4\%) prescrições sofreram alterações, tendo que 44 (15\%) delas suspensão de itens, utilizando para este fim a palavra “SUSPENSO” ao lado do medicamento.

Quanto às rasuras, ocorreram em 88 (29,9\%) prescrições analisadas sendo os nomes e as doses dos medicamentos os mais rasurados, 21 (7,1\%) e 17 (5,8\%) respectivamente.

5.2.2. Falhas ou problemas detectados no processo de dispensação e distribuição de medicamentos.

Na farmácia, aberta 24 horas, com a presença de técnicos de farmácia e mensageiro, não são feitos preparos de medicação, com exceção dos quimioterápicos e da nutrição parenteral total, que são adequadamente preparados e acondicionados pelos farmacêuticos. Estes profissionais auxiliam na dispensação e distribuição de medicamentos, por sistema individualizado, mas não realizam revisão das prescrições, avaliação da terapêutica, das alergias, das doses excessivas etc. 
A farmácia é rigorosa quanto ao fornecimento dos psicotrópicos, exigindo o envio da folha de prescrição e de um formulário específico preenchido e assinado pelo médico; no entanto, não possui controle dos mesmos após saírem de lá. $\mathrm{Na}$ clínica, a enfermagem acondiciona os psicotrópicos juntamente com os demais medicamentos e também não tem controle efetivo sobre sua utilização.

O hospital não possui uma central de informação sobre medicamentos (CIM), assim como a clínica médica não possui atualização dos medicamentos disponíveis. Há, entretanto, a “Comissão de Farmácia e Terapêutica”, composta por 01 representante dos seguintes setores: clínica médica, pediatria, anestesiologia, unidade de terapia intensiva, farmácia e enfermagem, designada pela diretoria do hospital para regulamentar a padronização de medicamentos no receituário hospitalar.

A seguir, apresentaremos, na Tabela 3, as freqüências dos relatos de situações identificadas como falhas ou problemas e as categorias da dispensação e distribuição de medicamentos. 
TABELA 3 - Problemas identificados no processo de dispensação de medicamentos do sistema de medicação de um Hospital Universitário de Goiás, segundo categoria, descrição e freqüência de relatos. Goiânia, 2002

\begin{tabular}{|c|c|c|c|}
\hline \multirow{2}{*}{ CATEGORIA } & \multirow{2}{*}{ DESCRIÇÃO DO PROBLEMA } & \multicolumn{2}{|c|}{ RELATOS } \\
\hline & & $\mathbf{N}$ & $\%$ \\
\hline \multirow{5}{*}{ Ambiente } & 1. Interrupções na tarefa & 5 & 13,9 \\
\hline & 2. Problemas relacionados a ruídos & 2 & 5,6 \\
\hline & $\begin{array}{l}\text { 3. Outras características do ambiente } \\
\text { (tumultuado) }\end{array}$ & 2 & 5,6 \\
\hline & $\begin{array}{l}\text { 4. Problemas relacionados ao } \\
\text { mobiliário }\end{array}$ & 1 & 2,8 \\
\hline & $\begin{array}{l}\text { 5. Problemas relacionados à } \\
\text { temperatura do ambiente }\end{array}$ & 1 & 2,8 \\
\hline Subtotal & & 11 & 30,6 \\
\hline \multirow[t]{2}{*}{$\begin{array}{l}\text { Problemas na conferência } \\
\text { dos medicamentos }\end{array}$} & $\begin{array}{l}\text { 1. Falhas na técnica de conferência dos } \\
\text { medicamentos }\end{array}$ & 5 & 13,9 \\
\hline & 2. Falta de dupla conferência & 2 & 5,6 \\
\hline Subtotal & & 7 & 19,4 \\
\hline Violações de regras & $\begin{array}{l}\text { 1. Atividades desenvolvidas por pessoal } \\
\text { não habilitado }\end{array}$ & 6 & 16,7 \\
\hline Subtotal & & 6 & 16,7 \\
\hline Problemas relacionados à & 1. Falta de medicamento & 3 & 8,3 \\
\hline dispensação e estoque de & 2. Falta de funcionário & 2 & 5,6 \\
\hline medicamentos & $\begin{array}{l}\text { 3. Problemas com medicamento } \\
\text { dispensado }\end{array}$ & 1 & 2,8 \\
\hline Subtotal & & 6 & 16,7 \\
\hline Problema do indivíduo & $\begin{array}{l}\text { 1. Falhas no comportamento do } \\
\text { profissional }\end{array}$ & 3 & 8,33 \\
\hline Subtotal & & 3 & 8,3 \\
\hline $\begin{array}{l}\text { Problemas de informação } \\
\text { sobre medicamento }\end{array}$ & $\begin{array}{l}\text { 1. Falhas no fornecimento de } \\
\text { informações sobre medicamentos }\end{array}$ & 2 & 5,6 \\
\hline Subtotal & & 2 & 5,6 \\
\hline $\begin{array}{l}\text { Problemas de solicitação e } \\
\text { requisição }\end{array}$ & $\begin{array}{l}\text { 1. Falhas no preenchimento de } \\
\text { formulários }\end{array}$ & 1 & 2,8 \\
\hline Subtotal & & 1 & 2,8 \\
\hline Total de relatos & & 36 & 100 \\
\hline
\end{tabular}

Os dados apresentados na Tabela 3 demonstram que os problemas relacionados ao ambiente foram os de maior importância identificados durante o processo de dispensação de medicamentos, sendo citados em 11 (30,6\%) relatos. 
A Tabela 3 indica que $7(19,4 \%)$ problemas identificados referiam-se à conferência dos medicamentos, pelo fato de os técnicos de farmácia não olharem o rótulo do medicamento, mas apenas a identificação existente no escaninho, ao dispensarem os medicamentos e a falta de dupla conferência.

Problemas de violação de regras foram citados em 6 (16,7\%) relatos, que mencionaram o fato de funcionários assumirem responsabilidades em desacordo com suas funções. Como exemplo, os mensageiros realizavam a dispensação e forneciam informações a respeito de medicamentos, na ausência de farmacêuticos e de técnicos de farmácia.

A Tabela 3 aponta ainda que 6 (16,7\%) problemas identificados referiam-se à dispensação e estoque de medicamentos, em decorrência da falta de medicamentos ou de funcionários, assim como envio incorreto dos mesmos.

Os resultados indicam que as alterações que permitirão melhorar a dispensação de medicamentos devem estar focadas no ambiente e na conferência dos medicamentos.

\subsubsection{Falhas ou problemas detectados no processo de preparo e administração de medicamentos.}

O processo da administração de medicamentos incorpora o seu preparo (separação, identificação, diluição), a administração, propriamente dita, o monitoramento e o registro realizado.

O sistema de dose individualizada não prevê estoque de medicamentos nas clínicas, entretanto, identificamos que não há controle da devolução para a farmácia 
daqueles que não são usados pelos pacientes, ficando sob responsabilidade dos profissionais de enfermagem evitar que pequenos estoques existam, prevenindo erros na medicação.

Para administração de medicamentos por via endovenosa há equipamentos que auxiliam no controle do volume infundido, como a bomba de infusão. No hospital em estudo foi identificado que as estas são de uma única marca, devido ao fato de terem sido doadas ao hospital. Isto facilita o trabalho da equipe, porém se houver necessidade da compra de mais bombas, a decisão basear-se-á na questão econômica e não na padronização dos instrumentos.

A seguir, apresentaremos na Tabela 4, as freqüências dos relatos de situações identificadas como falhas ou problemas e as categorias da administração de medicamentos, obtidas por meio de observações do preparo e da administração de medicamentos. 
TABELA 4 - Problemas identificados no processo de preparo e administração de medicamentos do sistema de medicação de um Hospital Universitário de Goiás, segundo categoria, descrição e freqüência de relatos. Goiânia, 2002

\begin{tabular}{|c|c|c|c|}
\hline \multirow[b]{2}{*}{ CATEGORIA } & \multirow{2}{*}{ DESCRIÇÃO DO PROBLEMA } & \multicolumn{2}{|c|}{ RELATOS } \\
\hline & & $\mathrm{N}$ & $\%$ \\
\hline \multirow[t]{5}{*}{$\begin{array}{l}\text { Problema durante o } \\
\text { preparo de } \\
\text { medicamentos }\end{array}$} & $\begin{array}{l}\text { 1. Preparo baseado em etiquetas que são } \\
\text { cópias dos medicamentos prescritos, feitas } \\
\text { por diversos profissionais. }\end{array}$ & 10 & 16,7 \\
\hline & $\begin{array}{l}\text { 2. Falhas na segurança durante técnica do } \\
\text { preparo de medicamento }\end{array}$ & 10 & 16,7 \\
\hline & 3. Preparo do medicamento antecipado & 3 & 5,0 \\
\hline & 4. Interrupções durante o preparo & 4 & 6,7 \\
\hline & 5. Conversa durante a realização da tarefa & 1 & 1,7 \\
\hline
\end{tabular}

Subtotal

Problemas durante a administração de medicamentos

1. Falha de segurança durante a técnica

2. Execução de outras atividades concomitantes à administração

3. Falha na relação com o paciente

4. Falhas no monitoramento

5. Atraso na administração

6. Falha na identificação do paciente

7. Potencial para erro de dose

\section{6,8}

$7 \quad 11,7$

$4 \quad 6,7$

$4 \quad 6,7$

$1 \quad 1,7$

$1 \quad 1,7$

$1 \quad 1,7$

$1 \quad 1,7$

\section{Subtotal}

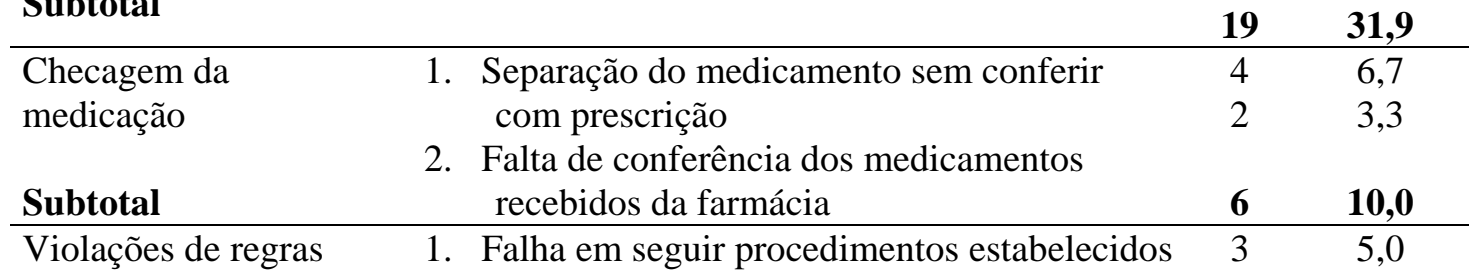

\section{Subtotal}

\section{Problemas} relacionados à

dispensação e estoque de medicamentos
1. Falhas na dispensação prejudicando o preparo

2. Falhas na comunicação sobre reposição de estoque e fornecimento de medicamento para a unidade, atrasando o preparo e administração

\section{Subtotal}

Ambiente

1. Problemas relacionados à iluminação

\begin{tabular}{ll}
$\mathbf{3}$ & $\mathbf{5 , 0}$ \\
\hline 2 & 3,3 \\
1 & 1,7
\end{tabular}

Subtotal 
Encontramos em $28(46,8 \%)$ relatos problemas relacionados ao preparo, tais como: preparo com base nas etiquetas e não nas prescrições, falhas na segurança do paciente, preparo antecipado dos medicamentos, interrupções e conversas (Tabela 4). Problema durante a administração de medicamentos, propriamente dita, foi citado em 19 (31,9\%) relatos referentes à falhas na segurança como: não-lavagem de mãos; reencape de agulhas; execução de atividades concomitantes como fazer hemoglicoteste e verificar sinais vitais dos pacientes entre um medicamento e outro; falha na relação com paciente, ao não explicar a ele qual medicamento está sendo administrado e para que serve.

Apresentaremos na Tabela 5, as falhas e problemas encontrados na análise das anotações de enfermagem e nos relatórios de enfermagem, obtidos em 294 prontuários de pacientes hospitalizados na unidade de clínica médica. 
TABELA 5 - Número e freqüência das características referentes às anotações de enfermagem encontradas nos prontuários médicos de pacientes da unidade de clínica médica de um Hospital Universitário de Goiás. Goiânia, 2002

\begin{tabular}{l}
\hline CARACTERÍSTICAS DAS ANOTAÇÕES DE \\
$\begin{array}{l}\text { ENFERMAGEM } \\
\text { Horários padronizados } \\
\text { medicamentos }\end{array}$ \\
Sim
\end{tabular}

Total

294

294

275

269

265

255

Sem rasuras

Justificativa em caso de medicamento não-administrado

Sim

Não

Todos medicamentos administrados

Item não assinalado
109

50

115

20
93,5

91,5

90,1

86,7

Existência de observações relacionadas à administração de medicamentos

\begin{tabular}{lcc} 
Sim & 7 & 2,4 \\
Não & 287 & 97,6 \\
\hline
\end{tabular}

* Há mais de uma alternativa para esta questão

A Tabela 5 indica que há horários padronizados para administração de 100\% dos medicamentos prescritos e que os aprazamentos estavam corretos em 275 (93,5\%) prescrições; completos em 269 (91,5\%); legíveis em 265 (90,1\%) e sem rasuras em 255 (86,7\%).

Encontramos justificativas para medicamentos não-administrados em 109 (45,4\%) prescrições de medicamentos, sendo a mais freqüente o sinal em círculo em torno do horário aprazado, seguido da sigla NT (não tem), que somou 47 (16\%) anotações. Também apareceram as seguintes justificativas: falta na farmácia (4,4\%); paciente ausente $(4,4 \%)$; paciente recusou (3,1\%); não subiu da farmácia (2,4\%); controle vencido ou em falta (2,0\%); remédio com o paciente acabou (1\%) e jejum 
(1\%). A Tabela 5 indica ainda que dentre as prescrições analisadas, 115 (39,1\%) tiveram todos seus medicamentos administrados.

De um total de 294 folhas de prescrição analisadas foram encontradas apenas 7 (2,4\%) observações de enfermagem referentes à administração de medicamentos: HCTZ e adalat estão com o paciente; a dipirona SOS foi administrada porque o paciente estava com dor; paciente queixando de cefaléia sendo feito o medicamento do item 2; queixa de dor, sendo feito 40 gotas de dipirona; administrado item 11, pois paciente relata cefaléia; feito medicamento item 8 porque paciente estava referindo dor. Não encontramos nenhuma anotação com relação a reações adversas ou erros na medicação.

Acrescentamos que os erros na medicação não são investigados e nem há relatórios formais instituídos a respeito no hospital. Também não há diretrizes para fornecimento de informações a pacientes e familiares quanto ao uso de medicamentos, seus efeitos colaterais e reações, ficando a cargo do conhecimento, consciência e responsabilidade dos profissionais envolvidos a sua comunicação.

Também não há relatórios formais de ocorrências com medicamentos, existe apenas um livro de ocorrências gerais utilizado pelas enfermeiras para comunicação das mesmas entre os turnos. No período da coleta, encontramos nesse livro a seguinte anotação:

"Estava prescrito Adalat e Atensina de horário para o paciente. Durante a noite não foi administrado porque o paciente estava de jejum para colher sangue, conforme justificativa da funcionária na papeleta. Recebemos o paciente com crise hipertensiva ( $\uparrow 200)$ o que causou reclamação da médica assistente no meio da enfermaria. Favor conversar com a funcionária”. 
Após o relato, esse erro, provavelmente, deve ter ficado restrito ao conhecimento dos envolvidos. A maneira como esse fato foi tratado, não traz nenhum aprendizado coletivo, como preconizado por especialistas na área de prevenção de medicamentos, uma vez que a única decisão indicada no caso foi conversar com a funcionária. É muito provável que inexistam protocolos para administração de medicamentos a pacientes em jejum.

A seguir, apresentaremos os erros identificados na medicação, sob o ponto de vista dos profissionais entrevistados.

5.3. ERROS NA MEDICAÇÃO: TIPOS, CAUSAS, PROVIDÊNCIAS E SUGESTÕES DOS PROFISSIONAIS.

Apresentaremos estes resultados nas tabelas a seguir, sendo os mesmos distribuídos por categorias de profissionais, utilizando para este fim siglas, como: médicos (M); equipe de enfermagem (E); equipe da farmácia (F).

Realizamos um total de 40 entrevistas com profissionais dos três turnos de trabalho, sendo: 12 (30\%) médicos residentes; 4 (10\%) enfermeiras supervisoras, 14 (35\%) técnicos de enfermagem e 2 (5\%) auxiliares de enfermagem, somando 20 (50\%) profissionais de enfermagem. Entrevistamos, também, 3 (7,5\%) farmacêuticos e 5 técnicos de farmácia (12,5\%) totalizando 8 (20\%) profissionais da equipe de farmácia.

Os médicos entrevistados corresponderam a 75\% da população de residentes da clínica médica; os profissionais de enfermagem corresponderam a 33,33\% da 
equipe de enfermagem e os profissionais da farmácia corresponderam a 42, $10 \%$ da equipe de farmácia.

Os tipos de erros ou potencial para erros relacionados à medicação, percebidos pelos participantes, com maior freqüência em seu setor ou clínica, encontram-se na Tabela 6, a seguir. 
TABELA 6 - Número e freqüência de respostas referentes aos tipos de erros ou potencial para erros ocorridos na medicação, citados pelos profissionais entrevistados e distribuídos por categorias, em um Hospital Universitário de Goiás. Goiânia, 2002

\begin{tabular}{lccccc}
\hline CATEGORIAS & \multicolumn{3}{c}{ PROFISSIONAIS } & \multicolumn{2}{c}{ RESULTADOS } \\
\cline { 2 - 6 } & $\mathrm{M}$ & $\mathrm{E}$ & $\mathrm{F}$ & $\mathbf{N}$ & $\mathbf{2}$ \\
\hline Erros relacionados à prescrição & 11 & 23 & 11 & $\mathbf{4 5}$ & $\mathbf{2 9}$ \\
Erros relacionados ao horário. & 10 & 16 & 6 & $\mathbf{3 2}$ & $\mathbf{2 0 , 6}$ \\
$\begin{array}{l}\text { Erros relacionados ao preparo e } \\
\text { administração de medicamentos }\end{array}$ & 7 & 13 & 1 & $\mathbf{2 1}$ & $\mathbf{1 3 , 6}$ \\
$\begin{array}{l}\text { Erros relacionados à dispensação do } \\
\text { medicamento }\end{array}$ & 3 & 9 & 8 & $\mathbf{2 0}$ & $\mathbf{1 2 , 9}$ \\
$\begin{array}{l}\text { Erros relacionados ao registro do } \\
\text { medicamento }\end{array}$ & & & & & \\
$\begin{array}{l}\text { Erros relacionados à solicitação } \\
\text { Erros relacionados ao paciente }\end{array}$ & 5 & 12 & 1 & $\mathbf{1 8}$ & $\mathbf{1 1 , 6}$ \\
Erros por falhas de comunicação & 5 & 3 & - & $\mathbf{8}$ & $\mathbf{5 , 2}$ \\
Outros tipos & 6 & - & 1 & $\mathbf{7}$ & $\mathbf{4 , 5}$ \\
\hline Total & 3 & - & - & $\mathbf{3}$ & $\mathbf{1 , 9}$ \\
\hline
\end{tabular}

Legenda:

$\mathrm{M}=$ Médicos

$\mathrm{E}=$ Equipe de enfermagem

$\mathrm{F}$ = Equipe de Farmácia

A Tabela 6 mostra que os erros mais citados pelos entrevistados foram aqueles relacionados à prescrição de medicamentos com $29 \%$ dos resultados, seguidos dos erros relacionados ao horário com 20,6\% e ao preparo e administração dos medicamentos com 13,6\%.

Na Tabela 7 encontram-se as respostas sobre as causas dos erros relacionadas à medicação, identificadas nos relatos dos profissionais. 
TABELA 7- Número e freqüência de respostas referentes às opiniões dos profissionais sobre as causas de erros ocorridos na medicação, citadas pelos profissionais entrevistados e distribuídos por categorias, em um Hospital Universitário de Goiás. Goiânia, 2002

\begin{tabular}{lccccc}
\hline CATEGORIAS & \multicolumn{3}{c}{ PROFISSIONAIS } & RESULTADOS \\
\cline { 2 - 6 } & $\mathbf{M}$ & $\mathbf{E}$ & $\mathbf{F}$ & $\mathbf{N}$ & $\mathbf{\%}$ \\
\hline Falta de atenção & 3 & 13 & 5 & 21 & $\mathbf{2 7 , 6}$ \\
Falhas individuais & 6 & 6 & 3 & 15 & $\mathbf{1 9 , 7}$ \\
Excesso de trabalho e falta de tempo & 4 & 3 & 4 & 11 & $\mathbf{1 4 , 5}$ \\
$\begin{array}{l}\text { Problemas na administração e organização } \\
\text { dos serviços da unidade }\end{array}$ & 7 & 1 & 2 & 10 & $\mathbf{1 3 , 2}$ \\
$\begin{array}{l}\text { Problemas nas prescrições ou no sistema de } \\
\text { prescrições }\end{array}$ & 1 & 2 & 2 & 5 & $\mathbf{6 , 6}$ \\
$\begin{array}{l}\text { Falhas na comunicação e integração de } \\
\text { pessoas e setores }\end{array}$ & 2 & 2 & 1 & 5 & $\mathbf{6 , 6}$ \\
Outros problemas & & & & & \\
\hline Total & 5 & 3 & 1 & 9 & $\mathbf{1 1 , 8}$ \\
\hline
\end{tabular}

Legenda:

M = Médicos

$\mathrm{E}=$ Equipe de enfermagem

$\mathrm{F}$ = Equipe de Farmácia

A Tabela 7 indica que a falta de atenção foi considerada a principal causa para erro na medicação, sendo citada em 27,6\% dos relatos, seguida das falhas individuais, com 19,7\%. Nela também visualizamos que excesso de trabalho e falta de tempo foram considerados a terceira causa dos erros ocorridos, em 14,5\% das respostas. Observamos que o grupo estudado atribuiu muitos erros aos profissionais e não ao sistema.

Quanto às providências administrativas tomadas nos casos de erros na medicação, conhecidas pelos profissionais, as respostas encontram-se na Tabela 8. 
TABELA 8 - Número e freqüência de respostas referentes às providencias administrativas tomadas pela instituição, relativas a erros ocorridos na medicação, citadas pelos profissionais entrevistados e distribuídas por categorias, em um Hospital Universitário de Goiás. Goiânia, 2002

\begin{tabular}{|c|c|c|c|c|c|}
\hline \multirow[t]{2}{*}{ CATEGORIAS } & \multicolumn{3}{|c|}{ PROFISSIONAIS } & \multicolumn{2}{|c|}{ RESULTADOS } \\
\hline & $\mathbf{M}$ & $\mathbf{E}$ & $\mathbf{F}$ & $\mathbf{N}$ & $\%$ \\
\hline \multicolumn{6}{|c|}{ PROVIDENCIAS ADMINISTRATIVAS } \\
\hline Orientação e advertência & 8 & 13 & 7 & 28 & 50,0 \\
\hline Suspensão ou Demissão & - & 8 & 1 & 9 & 16,1 \\
\hline Relatório e Orientação & 2 & 4 & 2 & 8 & 14,3 \\
\hline Contatos e decisões pessoais & 1 & 1 & - & 2 & 3,6 \\
\hline Relatório e suspensão & - & 1 & - & 1 & 1,8 \\
\hline Reuniões & - & 1 & - & 1 & 1,8 \\
\hline Nenhuma providência & 1 & - & - & 1 & 1,8 \\
\hline Outros & - & 1 & - & 1 & 1,8 \\
\hline Total & 12 & 33 & 11 & 56 & 100 \\
\hline
\end{tabular}

\section{Legenda:}

$\mathrm{M}=$ Médicos

$\mathrm{E}=$ Equipe de enfermagem

F = Equipe de Farmácia

Identificamos que em $50 \%$ dos relatos (Tabela 8), os entrevistados mencionaram que a orientação e a advertência verbal ou escrita foram as medidas administrativas mais utilizadas na ocorrência de erro na medicação, seguidas de suspensão ou demissão, com $16,1 \%$ das respostas. Notamos que as medidas estão direcionadas aos indivíduos que erraram e não para o sistema.

No que concerne às sugestões dos profissionais para prevenção dos erros na medicação, estas encontram-se na Tabela 9. 
TABELA 9 - Número e freqüência de respostas referentes às sugestões para evitar erros ou potenciais para errar, citadas pelos profissionais entrevistados e distribuídas por categorias, em um Hospital Universitário de Goiás. Goiânia, 2002

\begin{tabular}{ccc|c|c|c|c}
\hline CATEGORIAS & \multicolumn{3}{c}{ PROFISSIONAIS } & \multicolumn{3}{c}{ RESULTADOS } \\
\cline { 2 - 5 } & & M & E & F & N & $\%$ \\
\hline
\end{tabular}

- Direcionadas aos Profissionais

\begin{tabular}{|c|c|c|c|c|}
\hline Alteração nas Atitudes individuais & 9 & 13 & 4 & 26 \\
\hline Educação Continuada & 4 & 5 & 5 & 14 \\
\hline Aumentar supervisão, vigilância e punições & 6 & 4 & - & 10 \\
\hline $\begin{array}{l}\text { Maior incentivo e melhores condições de } \\
\text { trabalho }\end{array}$ & 1 & 3 & - & 4 \\
\hline Realização de reuniões & 1 & 2 & - & 3 \\
\hline Subtotal & 21 & 27 & 9 & 57 \\
\hline
\end{tabular}

\section{- Direcionadas ao Sistema}

Informatização do Sistema

$\begin{array}{ccccc}- & 1 & 6 & \mathbf{7} & \mathbf{7 , 6} \\ 1 & 3 & 3 & \mathbf{7} & \mathbf{7 , 6} \\ 3 & 1 & 1 & \mathbf{5} & \mathbf{5 , 4} \\ & & & & \\ - & - & 5 & \mathbf{5} & \mathbf{5 , 4}\end{array}$

Alterações no processo de prescrição de medicamentos e avaliação no processo de dispensação

Reestruturação no quadro de pessoal e redistribuição de serviço

$\begin{array}{lllll}1 & 1 & 2 & 4 & \mathbf{4}, 3\end{array}$

Reestruturação física da clínica e do processo de preparo e administração de medicamentos

Padronizações e rotinas

Mensuração de atividades e erros

$\begin{array}{llll}2 & - & 2 & 2,2\end{array}$

Outros

2

\begin{tabular}{cccc}
- & 2 & 2 & 2,2 \\
- & 1 & 1 & 1,1 \\
- & - & 2 & 2,2 \\
8 & 20 & 35 & 38 \\
\hline 35 & 29 & 92 & 100 \\
\hline
\end{tabular}


A Tabela 9 indica que $62,0 \%$ das sugestões foram direcionadas aos profissionais, tendo alterações nas atitudes individuais recebido 28,3\% das respostas, seguidas da educação continuada com 15,2\% e aumento da supervisão, vigilância e punição com 10,9\%.

As sugestões voltadas para o sistema de medicação corresponderam a 38\% das respostas, sendo a maior parte delas citadas pelos profissionais da farmácia: informatização do sistema obteve 7,6\% das respostas; reestruturação da farmácia também 7,6\%; melhorar comunicação e interação entre setores e pessoas 5,4\%; alterações no processo de prescrição de medicamentos e avaliação no processo de dispensação também 5,4\%.

A seguir, na Tabela 10 apresentaremos os resultados referentes às opiniões sobre as falhas no sistema de medicação, que estão contribuindo para os erros. 
TABELA 10 - Número e freqüência de respostas referentes às opiniões sobre as falhas existentes no sistema de medicação, citadas pelos profissionais entrevistados e distribuídas por categorias, em um Hospital Universitário de Goiás. Goiânia, 2002

\begin{tabular}{|c|c|c|c|c|c|}
\hline \multirow[t]{2}{*}{ CATEGORIAS } & \multicolumn{3}{|c|}{ PROFISSIONAIS } & \multicolumn{2}{|c|}{ RESULTADOS } \\
\hline & $\mathbf{M}$ & $\mathbf{E}$ & $\mathbf{F}$ & $\mathbf{N}$ & $\%$ \\
\hline Falhas individuais dos profissionais & 6 & 10 & 1 & 17 & 27 \\
\hline $\begin{array}{l}\text { Falhas na etapa de prescrição de } \\
\text { medicamento }\end{array}$ & 4 & 4 & 2 & 10 & 15,9 \\
\hline Falhas na etapa da dispensação e entrega & 4 & 2 & 3 & 9 & 14,3 \\
\hline Falhas no gerenciamento do sistema & 5 & 2 & 1 & 8 & 12,7 \\
\hline Falhas com os controles & 3 & 4 & - & 7 & 11,1 \\
\hline Falhas na etapa do preparo e administração & - & 2 & 1 & 3 & 4,8 \\
\hline Falta de pessoal e sobrecarga de trabalho & 1 & 2 & - & 3 & 4,8 \\
\hline $\begin{array}{l}\text { Falha na comunicação, interação e } \\
\text { integração das equipes }\end{array}$ & 1 & 1 & 1 & 3 & 4,8 \\
\hline Outros & - & 1 & 1 & 2 & 3,2 \\
\hline $\begin{array}{l}\text { Falha da supervisão e educação continuada } \\
\text { dos profissionais }\end{array}$ & 1 & - & - & 1 & 1,6 \\
\hline Total & 25 & 28 & 10 & 63 & 100 \\
\hline
\end{tabular}

Legenda:

$\mathrm{M}=$ Médicos

$\mathrm{E}=$ Equipe de enfermagem

$\mathrm{F}$ = Equipe de Farmácia

A Tabela 10 mostra que, novamente, as questões direcionadas aos indivíduos foram as mais citadas, recebendo opiniões de $27 \%$ dos entrevistados a respeito das falhas do sistema, associadas a problemas existentes nas etapas de prescrição (15,9\%) e dispensação de medicamentos (14,3\%). 


\section{DISCUSSÃO}

Dentro da compreensão que os erros na medicação ocorrem não somente devido a fatores humanos, mas também a falhas no sistema, este estudo identificou e analisou o sistema de medicação e seus processos, compreendidos como uma coleção de etapas individuais ligadas umas às outras e desenvolvidas para atingir o propósito de um hospital universitário do estado de Goiás, que é prestar assistência de excelência e referência aos pacientes.

A análise dos dados evidenciou o sistema, assim como o desenvolvimento de cada um dos três processos, estruturas e recursos disponibilizados pela instituição.

\subsection{Sistema de medicação}

O sistema de medicação deve gerenciar as atividades gerais do hospital, no que diz respeito ao uso de medicamentos, através de suas políticas e diretrizes, portanto, neste tópico, discutiremos as características, procedimentos, regras e problemas identificados.

A análise do fluxograma do sistema de medicação identificou 60 atividades realizadas pelos profissionais, mostrando como esse sistema é complexo, contendo várias etapas em cada um dos processos, grande número de profissionais envolvidos e, conseqüentemente, maior chance de erro. As etapas, além de múltiplas, são 
interligadas e inter-relacionadas, fatores que podem comprometer a execução das etapas seguintes devendo, portanto, sofrer constante monitoração e controle da sua eficácia.

O sistema de medicação de um hospital pode conter de 20 a 30 passos diferentes, durante os processos de prescrição, dispensação e administração de medicamentos, podendo ocorrer: 39\% de erros no processo de prescrição, $12 \%$ no de transcrição, $11 \%$ no processo de dispensação e $38 \%$ no processo de administração de medicamentos (LEAPE et al., 1995; LEAPE et al.,2000). No entanto, no hospital investigado, observamos três vezes mais etapas do que as preconizadas, o que pode propiciar a ocorrência de maior número de erros.

Os erros cometidos e não interceptados conduzem a erros nos processos seguintes. Para que isso não ocorra, é necessário que a instituição tenha uma comissão ou coordenação multidisciplinar competente e atuante para realizar um controle rigoroso dos processos e buscar fatores que possam gerar erros.

Embora o hospital utilize um grande número de etapas, estas não refletem toda a complexidade do sistema, pois existem problemas não identificados no fluxo, como: falta de profissionais capacitados, de infra-estrutura, de conhecimento técnico, sobrecarga de trabalho, barreiras culturais que refletem na cooperação entre os profissionais, a rotatividade de profissionais e a cultura do imediatismo, que caracteriza o dia-a-dia hospitalar (KOHN et al., 2001; PHARMACY-NURSING, 2003).

No hospital em estudo, identificamos problemas como ambientes inadequados, violação de regras, problemas de legibilidade e falta de dados na 
prescrição, falha nas conferência dos medicamentos, na dispensação e falhas técnicas de segurança durante preparo e administração.

A análise do fluxograma e da descrição das atividades mostraram que os profissionais realizavam um grande número de ações e muitas delas de memorização, como preencher formulários de solicitação de antibióticos e psicotrópicos, ou lembrar a validade da autorização da CCIH para fornecimento do antibiótico. Constatamos, também, que, para conferir se os formulários, exigidos pela farmácia para fornecimento de psicotrópicos e antibióticos, estão preenchidos corretamente e anexos à prescrição, são envolvidos vários profissionais, o que despende tempo e trabalho. Se houvesse algum mecanismo do tipo check list, lembretes ou modelos ("templates") a serem seguidos facilitaria o trabalho e minimizaria as falhas encontradas (KOHN et al., 2001).

Sabemos que sistemas inseguros podem gerar graves conseqüências nas organizações de saúde, por isso é necessário buscar estratégias para prover um sistema seguro de medicação, capaz de auxiliar os profissionais na prevenção de erros, através de medidas que tragam facilidades para ação de medicar e dificuldades para as oportunidades de errar e que ainda melhorem a qualidade dos processos executados, podendo esta última conduzir a dois caminhos, como reduzir o número de etapas existentes ou melhorar a confiança em cada uma das etapas (MINDEN, 2003).

A American Society of Hospital Pharmacists (ASHP), em 1996, sugeriu que os hospitais devem criar barreiras e ações para minimizar os problemas relacionados aos erros na medicação, quais sejam: 
1. Estabelecer processos nos quais os médicos digitem a prescrição diretamente em sistemas computadorizados.

2. Avaliar o uso de máquinas leitoras de códigos (códigos de barra) no uso dos medicamentos, seja na administração para identificação positiva e detecção de erro de identidade, ou para gerar relatórios referentes ao controle de estoques e dispensação na farmácia.

3. Avaliar melhor o sistema para monitorar e relatar eventos adversos.

4. Adotar a distribuição de medicamentos por dose unitária e a preparação de injeções parenterais na farmácia.

5. Designar farmacêuticos para trabalhar de forma colaborativa com médicos e enfermeiros.

6. Abordar os erros na medicação como uma falha do sistema e procurar soluções para preveni-los.

7. Assegurar que as prescrições sejam rotineiramente revistas pelos farmacêuticos, antes da administração das primeiras doses e assegurar que os profissionais procurem resolver qualquer questão de segurança com respeito ao uso da medicação.

Nenhuma destas estratégias foi encontrada no hospital em estudo, que possui não só prescrição de medicamentos manual, como também são manuais os controles e checagens dos medicamentos administrados e estocados. Quanto ao controle de eventos adversos realizado pela gerência de risco, este não é específico para a medicação. A distribuição de medicamentos é por dose individualizada e não conta com farmacêuticos nas clínicas para conferência das doses prescritas. 
Um dos princípios apresentados no relatório do Comitê do Institute of Medicine para tornar a assistência prestada ao paciente mais segura, através de melhorias nos processos, baseia-se em respeitar os limites humanos desenhando o sistema de medicação através de práticas como: evitar atividades baseadas na confiança de suas memórias; utilizar mecanismos que forcem ações para que erros não aconteçam, como, não fornecer medicamentos se não houver informações sobre alergias, peso e idade; simplificar os processos diminuindo o número de etapas, o número de pessoas envolvidas nas mesmas atividades e, conseqüentemente, a probabilidade de erros (KOHN et al., 2001).

Medidas como não confiar na memória e simplificar os processos deveriam ser adotadas pelo sistema de medicação da instituição em estudo, principalmente quanto à forma de solicitar psicotrópicos e antibióticos pois, conforme descrito nas atividades do fluxograma, isso depende de que médicos se lembrem de preencher os formulários de maneira correta e, no caso dos antibióticos, precisam lembrar qual o período de fornecimento para não haver descontinuidade do tratamento. Simplificar esta atividade que depende da ação de vários profissionais em diferentes momentos do fluxo, poderia ser uma das soluções para minimizar erros e promover o fornecimento adequado do medicamento ao paciente. 
6.2. Falhas e problemas detectados nos processos de medicação.

Apresentaremos as falhas e problemas detectados com base nos processos nos quais eles foram identificados.

6.2.1. Problemas identificados no processo de prescrições de medicamentos.

A prescrição de medicamentos é o primeiro processo do sistema de medicação, sendo os profissionais médicos os responsáveis pelas definições e orientações sobre a terapia medicamentosa fornecidas aos demais membros da equipe de farmácia e de enfermagem.

Os erros que ocorrem nesse processo têm a chance de serem interceptados por meio de condutas e programas, nos quais as equipes de farmácia e de enfermagem intervêm junto ao prescritor e em busca de segurança para o paciente, atividade importante no cuidado destes. Porém, o grande número de fármacos e produtos comerciais disponíveis no mercado, lançados diariamente, e a enorme quantidade de interações e efeitos adversos produzidos pelos medicamentos, fazem com que esta importante etapa do processo de atendimento seja susceptível a erros (WEN, 2000). No hospital em estudo há padronização dos medicamentos utilizados, porém há inclusões de novos medicamentos por solicitação médica, que podem trazer problemas se não forem divulgadas entre os demais profissionais que as utilizam. 
A prescrição de medicamentos pode ser redigida em impresso específico de papel para este fim, digitada em computadores diretamente pelo médico ou ainda por um transcritor que copia a prescrição, em impresso próprio. Elas são elaboradas diariamente, com validade para 24 horas, e as modificações e acréscimos são introduzidos em caso de necessidade, ou de ações pontuais, como no caso de aplicação de contrastes em exames radiológicos.

Os dados mostraram que, no hospital em questão, as prescrições eram realizadas diariamente, de forma manual e em duas vias, em impresso próprio, podendo seu modelo ser alterado conforme disponibilidade do estoque do almoxarifado central, variando entre impressos em duas vias com um verso carbonado ou impresso de duas vias, com folha de carbono avulsa.

O fato da prescrição ser manual aumenta a incidência de erros, pois a grafia da equipe médica costuma ser, na maioria das vezes, de difícil leitura, causando, além de erros de interpretação, trabalho extra para as equipes de enfermagem e da farmácia que devem decifrá-las (LYONS et al., 1998; COHEN, 2000). A letra ilegível do médico foi considerada a quarta causa para ocorrência de erros na medicação no estudo de Bueno et al. (1998), embora neste estudo ela não tenha sido classificada como causa, mas sim como tipo de erro freqüente.

No hospital em estudo, a $2^{\mathrm{a}}$ via da prescrição de medicamentos (cópia carbonada) é enviada à farmácia para a dispensação dos mesmos, eliminando a necessidade de transcrição da prescrição, um fator positivo, devido à redução de um passo que poderia incorrer em erro na medicação. No entanto, o uso do carbono causa transtornos, como: sujeira nas mãos dos profissionais que manipulam as prescrições, além do que muitas pessoas utilizam a papeleta como apoio para 
escrever, esquecendo-se da existência do carbono, e assim rasuram a folha abaixo; também o carbono de má qualidade faz com que a cópia não apresente boa resolução, dificultando o trabalho dos profissionais da farmácia e facilitando a ocorrência de possível erro durante a dispensação do medicamento, devido ao fato de nem sempre imprimir caracteres como vírgulas, na segunda via. Vale ressaltar, a existência, atualmente, do papel de cópia sem carbono, lançado nos EUA, em 1954, pela National Cash Register, que utiliza o processo de microencapsulação e vem sendo usado com sucesso nos boletos bancários e notas fiscais, podendo vir a ser um avanço nesta questão (SOUZA, 2003).

Para minimizar os problemas na medicação devido às cópias realizadas da prescrição, torna-se importante, ainda, que os médicos conheçam o fluxo das duas vias das prescrições, para estarem cientes que uma simples alteração, após o encaminhamento da $2^{\mathrm{a}}$ via à farmácia, além de rasurar a prescrição, não garante o fornecimento do medicamento na dispensação, em caso de inclusão ou mesmo de troca de medicamento, se o fato não for comunicado à enfermagem ou mesmo à farmácia.

No que se refere ao ambiente da prescrição, o NCCMERP (1998) descreve alguns fatores que podem contribuir para a ocorrência de erros na medicação, como: iluminação, nível de ruído, interrupções freqüentes e distrações.

Em nosso estudo os problemas identificados no ambiente no qual os médicos realizam as prescrições despontaram como um dos maiores, pois apareceram em 65,2\% dos relatos, referindo-se a interrupções e distrações durante o processo de prescrever. Elas foram constantes e ocorreram por causa de telefone, por 
interferência de outros profissionais da equipe, ou de um colega, dificultando a necessária concentração que exige o ato de prescrever.

O ruído existente nos locais destinados à prescrição, assim como a falta de espaço restrito para esse fim, desorganização e má ventilação também influenciaram o resultado. Os médicos não possuem um lugar próprio e específico que lhes dê condições de prescrever com tranqüilidade, com acesso a informações, como: manual de padronizações, dicionários de especialidades farmacêuticas, manuais sobre interação medicamentosa etc e contato direto com a farmácia.

No local estudado existem dois ambientes para a prescrição, um é o posto de enfermagem, situado no corredor da clínica, onde nem sempre há lugar para todos. O ruído no local é intenso: conversas, risadas e telefone tocando incessantemente. O outro, é um espaço reservado para estudos e reuniões dos acadêmicos que freqüentam a clínica, que comporta apenas uma mesa de madeira $(1,50$ x 0,90 cm) e um banco de madeira para quatro pessoas. Este local fica na passagem para a sala de repouso médico e é também passagem para a escada que leva ao andar superior do prédio, com trânsito intenso de pessoas. A iluminação é razoável, mas o local é abafado, devido à ventilação precária. A mesa está sempre desarrumada cheia de papéis, mochilas, cadernos e livros.

O trabalho sob condições adversas, como disposição inadequada do ambiente, calor, ruído e tensões psicológicas extremas, pode levar o ser humano a cometer erros e dificilmente o profissional consegue controlar sozinho os riscos de sua atividade. Desse modo, devemos estar alertas a estes indicadores, descobrir falhas, discutir, planejar, promover melhorias através da construção de sistema de segurança para prevenção de acidentes no processo de medicação (CARDELLA, 1999). 
O NCCMERP enfatiza ainda que a ilegibilidade das prescrições de medicamentos pode causar danos ou até levar pacientes à morte. Com intuito de minimizar erros, este conselho faz algumas recomendações para a confecção das prescrições legíveis, como: utilizar o sistema computadorizado; evitar o uso de abreviaturas, mesmo as padronizadas, devido ao perigo de serem mal compreendidas; evitar prescrições vagas como "tomar como indicado" ou "se necessário”; devem conter uma breve anotação referindo-se ao propósito daquele medicamento (ex: para tosse); escrevê-las no sistema métrico, exceto as terapias como insulina, vitaminas e aquelas que usam unidades padronizadas; utilizar sempre a palavra unidade escrita por inteiro ao invés de somente a letra U; os zeros devem preceder sempre uma expressão decimal menor do que um (ex: 0,5 ml) e nunca após (5,0 ml); as prescrições devem incluir idade e peso, principalmente nas unidades de pacientes pediátricos e idosos; também devem incluir nome, dosagem e a concentração dos medicamentos (NCCMERP, 1996).

A análise dos 294 prontuários médicos mostrou que 34,7\% das prescrições estavam ilegíveis, ou parcialmente legíveis, problema reconhecido como causa de erro na medicação. Quanto à má grafia dos prescritores, esta obteve o segundo lugar, como mais prevalente numa lista de 90000 queixas, compiladas no período de sete anos, sobre más práticas detectadas na medicação, segundo relatório do American Medical Association. A ilegibilidade da prescrição pode levar à má interpretação da terapia desejada, portanto os médicos que possuem caligrafia ruim devem fazer com que as informações tornem-se claras para toda a equipe que irá utilizá-las (CABRAL, 1997; COHEN, 2000). 
Para melhor ilustrar a dificuldade encontrada pelos auxiliares de pesquisa, ao analisarem os 34,7\% de prescrições de medicamentos com letras ilegíveis ou legíveis apenas em parte, apresentaremos alguns comentários registrados durante a pesquisa:

"Por vezes as letras se confundem não permitindo uma leitura corrente".

"Não entende se é mg ou $\mathrm{g}, \mathrm{ml}$ ou l, as palavras têm suas letras encavaladas".

"Letra muito ruim. Palavras ficam ilegíveis. Tem que fazer muito esforço para compreender além de ter experiência”.

“Dá para decifrar algumas palavras, outras são ilegíveis”.

“Deixa dúvida na apresentação, no nome do medicamento, há rasura, dúvida no volume a ser diluído”.

A análise dos prontuários apontou também que as prescrições apresentavamse incompletas tanto com relação a dados do paciente, quanto do médico e da terapia medicamentosa.

Nome do paciente ilegível ou correto foi encontrado em 9,2\% das prescrições, fato que preocupa, pois pode desencadear erro na medicação por troca de paciente. Vale acrescentar que, neste hospital, o paciente não utiliza pulseiras de identificação o que leva os profissionais a recorrerem à folha de prescrição de medicamentos para se certificarem do nome do paciente, na hora da administração dos medicamentos. Também o nome completo e legível do médico ou CRM não apareceram em 37,8\% das prescrições, sendo que em 25 destas encontramos apenas o nome do acadêmico de medicina ( $5^{\circ}$ ano), que não pode se responsabilizar pela terapia medicamentosa 
por não ter se graduado ainda e estar em fase de treinamento, portanto, não podem assumir legalmente a terapia, principalmente em caso de erro.

A prescrição de medicamentos nesta instituição utiliza ora nomes comerciais, ora nomes do princípio ativo, o que pode gerar erros na dispensação ou na administração destes medicamentos, devido à gama de nomes que os profissionais são obrigados a identificar e a conhecer para utilizá-los de maneira correta, pois para cada nome de princípio ativo há vários nomes comerciais. O ideal seria que as duas formas fossem utilizadas concomitantemente, para um mesmo medicamento, havendo assim a confirmação do medicamento desejado ou a padronização apenas do nome genérico (COHEN, 2000).

Os dados indicam que 94,9\% das prescrições estavam incompletas para um item ou mais, sendo que a redação da forma de apresentação do medicamento faltou em 77,6\% das prescrições, item este necessário para se considerar uma informação completa e adequada para evitar erros ou falta de entendimento. Um outro fato observado refere-se à diluição que também não apareceu redigida em 37,8\% das prescrições analisadas.

Toda prescrição de medicamentos deve conter o nome e o registro do paciente, especialidade farmacêutica, a dose, a forma, a diluição, concentração, quantidade, a freqüência de administração e a via de administração, a duração da terapia e o nome e assinatura do médico, assim como número de seu registro no conselho profissional (ASHP, 1993). E no que diz respeito a essas informações, cabe à enfermagem solicitar ao médico que elas sejam completas, mesmo que o dado pareça óbvio ou que sua experiência profissional permita saber como proceder em casos de uma informação omitida. 
A equipe multidisciplinar, responsável pela medicação do paciente, necessita de informações básicas sobre o mesmo, como nome, número de leito, idade, peso e altura até as mais complexas como níveis sanguíneos, resultados de exames laboratoriais, quantidades de psicotrópicos recebidos nas últimas horas etc, como medidas de segurança para o tratamento medicamentoso (LEAPE et al., 1995). Para uma comunicação eficiente, os dados devem ser objetivos, claros e completos.

As prescrições feitas em sistema computadorizado, dependendo de como o programa foi desenhado, podem ser uma alternativa para melhorar a segurança do processo de prescrever, por várias maneiras: em primeiro lugar porque todas as prescrições devem conter, obrigatoriamente: a dose, a via e a freqüência; em segundo, devem ser legíveis, identificando aquele que a fez a todo o momento; em terceiro, informações referentes ao paciente devem ser fornecidas ao médico durante o processo e em quarto, durante a prescrição devem ser detectados fatores que possam predispor o paciente a risco de reações adversas (BATES, 2000). Como sabemos, o custo de sua implantação é alto para os padrões brasileiros, no entanto, vale considerar que o custo de eventos adversos ao medicamento evitáveis fica em torno de US\$ 2,8 milhões/ ano e que as economias diretas com a redução de eventos adversos foram estimadas em mais de US\$ 500.000 ao ano, em um hospital-escola que utiliza este sistema de prescrição (BATES et al., 1997; KOHN et al., 2001).

Em relação às abreviaturas, elas foram encontradas em $95,9 \%$ das prescrições, sendo muitas delas empregadas comumente pelos profissionais de saúde, como VO, IV, IM. Porém mesmo sendo conhecidas elas dificultam a compreensão e a execução da prescrição pela equipe de enfermagem e da farmácia, pois, em caso de escrita ruim podem ser confundidas com outra abreviatura. O uso de abreviaturas 
para vias de administração, nomes e dosagens de medicamentos não é recomendado a não ser que haja uma padronização e que seus significados sejam divulgados a toda equipe.

As abreviaturas economizam o tempo do prescritor, porém se mal empregadas podem causar equívocos de interpretação, aumentam o trabalho dos profissionais que devem compreendê-las, pois uma abreviatura pode ter mais de um significado e o leitor não estando familiarizado com ela pode confundi-la com outra (COHEN, 2000).

A seguir, discutiremos e analisaremos os dados obtidos no segundo processo do sistema: o processo de dispensação e distribuição de medicamentos.

6.2.2. Problemas identificados no processo de dispensação e distribuição de medicamentos

O processo de dispensação e distribuição de medicamentos só ocorre após a conclusão do processo de prescrição e o encaminhamento destas à farmácia do hospital. Os erros mais comuns que ocorrem neste processo são os de cálculo, de preparo, de dispensação e na distribuição (KELLY, 1995).

A farmácia do hospital permanece aberta 24 horas por dia à disposição das clínicas, com técnicos de farmácia e mensageiro em todos os períodos, fator importante e altamente recomendado para o sistema de medicação, pois torna-se desnecessário o armazenamento de medicamentos nas unidades, uma vez que atende às necessidades em qualquer horário. 
O sistema de distribuição dos medicamentos é o de doses individualizadas, para um período de 24 horas, sistema avançado se comparado ao sistema coletivo no qual cada unidade clínica possui estoques de medicamentos dentro dos postos de enfermagem. Neste sistema diminuem as oportunidades de haver prejuízos financeiros à instituição causados por vencimento das datas de validade dos medicamentos, por acondicionamentos inadequados, por distanciamento entre o gasto com a aquisição e recebimento pelo uso do medicamento, sem falar na probabilidade menor de ocorrer erros na administração devido à grande disponibilidade e variedade de medicamentos.

Para que os medicamentos saiam da farmácia e cheguem até os pacientes nas clínicas, existem os sistemas de distribuição abaixo descritos (GARRISON, 1979 apud RIBEIRO, 1991, p. 25; COIMBRA et al., 1998; MALUVAYSHI \& SANTOS, 2004):

1. No sistema de distribuição coletiva, a farmácia dispensa e envia uma determinada quantidade de medicamento aos setores. Normalmente estes são solicitados e mantidos pela enfermagem e administrados conforme a necessidade. Este sistema dificulta o controle do estoque no que se refere à qualidade dos produtos e da quantidade existente nos estoques e pode, também, gerar aumento nos gastos dos hospitais, pois possibilita desvios, perda de medicamentos por acondicionamento indevido, perda da validade.

2. No sistema de distribuição individualizada, os medicamentos são dispensados e distribuídos para a unidade com base na prescrição médica de cada paciente. Os medicamentos são dispensados para o paciente por um ou mais dias, ficando estocados na unidade sob responsabilidade da enfermagem até o momento da 
administração. A distribuição individualizada pode ser classificada conforme o tipo de impresso utilizado, ou seja, sistema individualizado indireto quando se faz uso da transcrição da prescrição e sistema individualizado direto quando se utiliza a própria prescrição ou sua cópia direta. Este sistema, além de diminuir o estoque de medicamentos na unidade permite maior controle dos medicamentos, por parte dos farmacêuticos.

3. Sistema de distribuição de medicamentos por dose unitária - SDMDU. Nele, a medicação é preparada pelo profissional da farmácia com base na cópia da prescrição original, sendo encaminhada a seguir, para a enfermagem, que deverá administrá-la. Neste caso, os medicamentos são acomodados em embalagens unitárias já prontas para a administração, sendo alguns diluídos, com horários e identificações. A implantação da dose unitária nos hospitais significou uma das maiores mudanças sistêmicas que reduziram os erros na medicação, porém ainda é pouco utilizada no Brasil e de difícil implantação neste momento, no hospital em estudo, pois a equipe de farmácia é constituída por apenas quatro farmacêuticos.

Vale ressaltar, que para a Organização Nacional de Acreditação (ONA) a existência dos sistemas de dispensação e distribuição por doses individualizadas ou unitárias é um dos critérios de avaliação de qualidade da instituição, classificando como padrão nível 2, padrão de qualidade no atendimento, da farmácia aqueles hospitais que os possuem (UETA et al., 2004).

No Brasil, ainda é muito utilizada a forma semi-individual que é uma combinação de dois tipos, quais sejam: a distribuição individual mediante a prescrição médica, mas com um percentual de estocagem de medicamentos que permanece no setor. 
Pereira et al. (1999) relatam que a distribuição de medicamentos é um aspecto estratégico dentro do hospital, seja do ponto de vista de segurança do paciente, seja do aspecto econômico do hospital ou em termos de controle de infecção hospitalar. A existência de um sistema de distribuição de medicamentos foi observada em 100\% das instituições hospitalares estudadas pelos autores, sendo a distribuição por dose individualizada (89\%) a mais comum.

Porém alguns problemas e erros na medicação podem estar associados à distribuição individualizada de medicamentos como (Castro, 2001):

- Omissão de distribuição: o medicamento não é enviado à unidade;

- Superdose: enviada uma dose maior do que a prescrita;

- Sub dose: enviada uma dose menor do que a prescrita;

- Dose extra: enviado um medicamento em quantidade maior do que a prescrita;

- Fracionamento inadequado: enviado uma forma farmacêutica que não permite o fracionamento necessário para atender à prescrição.

- Medicamento errado: distribuição de medicamento que não foi prescrito;

- Forma farmacêutica trocada: medicamento certo na forma farmacêutica errada;

- Problemas com a forma farmacêutica: medicamento distribuído com integridade física comprometida ou outra alteração constatável macroscopicamente;

- Medicamento vencido: distribuição de medicamentos com prazo de validade expirado; 
- Distribuição de medicamentos sem prescrição: medicamentos enviados à clínica sem terem sido solicitados;

- Interpretação inadequada da prescrição: medicamento distribuído de forma inadequada, devido a problemas na compreensão da prescrição.

Este estudo não realizou busca ativa de erros no sistema de distribuição de medicamentos, especificamente, por isso não tem dados que ratifiquem estas afirmações; no entanto, a prática diária na clínica e informações dos profissionais da instituição sugerem a realização de outros estudos para busca de informações que estejam de acordo com o citado anteriormente.

Identificamos que as clínicas não recebem informações atualizadas sobre medicamentos novos incluídos no estoque e na lista de padronizados, sendo estas fornecidas aos médicos e à enfermagem somente quando são feitas ligações telefônicas para a farmácia. Ressaltamos ainda, que há falha na comunicação sobre os medicamentos disponíveis no estoque para o consumo diário, causando transtornos para os médicos que não sabem se podem ou não prescrever determinados medicamentos, por desconhecerem quais se encontram disponíveis ou em falta na farmácia.

Alguns hospitais brasileiros possuem o Centro de Informações sobre Medicamentos que desenvolve atividades, tais como: (HOSPITAL ISRAELITA ALBERT EINSTEIN, 2001).

- Informação a todos os profissionais da instituição, sanando as dúvidas técnicas ligadas ao uso do medicamento nos processos de prescrição, dispensação e administração de medicamentos. 
- Acompanhamento da padronização de medicamentos realizada pela Comissão de Farmácia e Terapêutica, através de fornecimento de relações de medicamentos, elaboração de planilhas, participação nas discussões e na emissão de relatórios sobre prescrição de medicamentos não padronizados.

- Fornecimento de suporte técnico, capacitação, treinamento na implantação de atividades e na utilização de ferramentas de trabalho.

- Assistência farmacêutica, através da qual as prescrições médicas são analisadas pelo farmacêutico, para verificação da identificação correta do medicamento, dose a ser utilizada, via e horário de administração, considerando-se dados como peso, diagnóstico, antecedentes e alergias para garantir o tratamento correto e monitorar eventos adversos.

Verificamos que no hospital em estudo não existe Centro de Informações sobre Medicamentos, nem qualquer outro sistema que esclareçam aos médicos, equipes de enfermagem e farmácia suas dúvidas.

Fontes de informações a respeito de medicamentos são imprescindíveis, pois o número de medicamentos disponível para terapia medicamentosa é imenso. De 1987 a 1995 o Food and Drug Administration incluiu aproximadamente 225 novos medicamentos no mercado, para serem utilizados pelos médicos (LESAR et al., 1997). No que diz respeito ao Brasil, existem mais de 12.000 medicamentos de uso corrente se considerarmos os remédios homeopáticos e fitoterápicos, produtos hospitalares, formulações e apresentações múltiplas (SABBATINI, 1998). Nesse sentido, não se pode exigir que os médicos conheçam todos os medicamentos que irão prescrever e monitorar no paciente hospitalizado; estes tampouco podem depender da sua memória para que estas informações sejam utilizadas no momento 
da prescrição, dispensação e administração de medicamentos (LESAR et al., 1997; SABBATINI, 1998).

Daí a necessidade de o hospital viabilizar a criação do centro de informações para que os profissionais possam buscar auxílio para realizar suas atividades com conhecimentos atualizados e seguros, como acontece em hospitais americanos.

A Organização Nacional de Acreditação (ONA) mantém, também, como um dos critérios de avaliação da qualidade do atendimento prestado aos pacientes, a existência da Comissão de Farmácia e Terapêutica, afim de que o serviço de farmácia obtenha classificação no padrão nível 3, padrão de excelência. Esta comissão realiza o planejamento estratégico do uso de medicamentos (UETA et al., 2004).

Detectamos que no hospital em estudo, há a "Comissão de Farmácia e Terapêutica”, designada pela diretoria do hospital e que tem a finalidade de regulamentar a padronização de medicamentos no receituário hospitalar. Em 2001, esta comissão distribuiu para todas as clínicas do hospital a segunda edição de um guia terapêutico, contendo o estatuto da comissão; normas para solicitação de medicamentos de alto custo, para solicitação de medicamentos não-padronizados, para solicitação de medicamentos sujeitos a controle legal, para solicitação de antimicrobianos, para solicitação de nutrição parenteral, além da classificação terapêutica dos medicamentos padronizados (UNIVERSIDADE FEDERAL DE GOIÁS, 2001). Porém, durante este estudo verificamos que este guia não era utilizado pela equipe médica, sendo até desconhecido por alguns profissionais.

Os meios de comunicação entre farmácia e profissionais da clínica devem ser ampliados, abrangendo questões concernentes à medicação (erros, causas, 
orientações), devendo os mesmos ser cada vez mais explorados, divulgados e estimulados entre as equipes.

Assim como no processo de prescrição, problemas de ambiente também foram identificados na dispensação tais como: interrupções, ruídos, tumulto, mobiliários e temperatura do ambiente.

As interrupções feitas aos funcionários da farmácia foram causadas por chamadas ao telefone, conversas paralelas ao serviço e ruídos advindos do ar condicionado, da televisão ligada, do toque do telefone e das conversas, no local.

O NCCMERP recomenda que a área de dispensação seja projetada para prevenir erros e esse projeto deve ser direcionado às condições ambientais, a fim de reduzir a fadiga (iluminação, ar condicionado, nível de ruído, instalações ergonômicas); diminuir as distrações (telefone e interrupções de pessoal, desordem, tarefas sem conexões); e fornecer recursos suficientes à carga de trabalho dos profissionais (NCCMERP, 1999).

No espaço da farmácia, reservado para dispensação dos medicamentos, existe um aparelho de ar condicionado, que nem sempre funciona bem, mantendo a temperatura elevada em determinados dias e horas tornando o ambiente muitas vezes insalubre para o trabalhador. Também existem problemas com o mobiliário destinado à separação da medicação. Nesse local as mesas são repletas de caixas de medicamentos, papéis, livros de controles, prescrições e medicamentos, que estão sendo separados pelos técnicos. Os profissionais usam o espaço também para o lanche.

O NCCMERP e a American Society of Health - System Pharmacists sugerem também que os hospitais garantam a revisão rotineira, por parte de farmacêuticos, 
das prescrições antes que as primeiras doses sejam administradas ao paciente e que qualquer prescrição incompleta, ilegível, ou que contenha qualquer outra dúvida seja esclarecida antes da dispensação (ASHP, 1996; NCCMERP, 1999). Vale ressaltar ainda que no hospital em estudo não há farmacêuticos alocados nas clínicas de internação, o que não é problema somente deste hospital, mas dos hospitais brasileiros, de uma forma geral.

O papel do farmacêutico vem sendo ampliado, em virtude da complexidade da terapêutica medicamentosa. Além de fundamental na dispensação e distribuição dos medicamentos, este profissional passa a ser o responsável pela aquisição, uso e orientação sobre medicamentos, seja disponibilizando seus conhecimentos específicos para a equipe médica, de enfermagem e pacientes, seja participando das decisões sobre terapêutica medicamentosa, esclarecendo dúvidas dos profissionais durante prescrições e administrações de medicamentos. Nos hospitais onde há o farmacêutico clínico, este está presente no momento em que a prescrição está sendo redigida e nas visitas médicas, para dar suporte à decisão clínica e participa como membro da equipe e fonte de consulta rápida à equipe de enfermagem, sobre segurança nos medicamentos (CASSIANI, 2000b; UETA et al., 2004).

Farmacêuticos clínicos realizaram, em quatro anos e meio, 14.983 intervenções nos processos de prescrição e administração de medicamentos em uma unidade de internação de cardiologia, num hospital dos EUA, e puderam prevenir mais de 4.000 erros na medicação, confirmando a importância da atuação desse profissional junto com à equipe que está próxima ao paciente (LAPOINTE \& JOLLIS, 2003). 
Em relação às conferências e revisões das prescrições durante a dispensação, salientamos que, no hospital do estudo, há apenas um farmacêutico por turno, e não é designada a ele a responsabilidade de identificar alergias, doses excessivas ou sub doses, analisar interações medicamentosas etc, e sim conferir os itens que são prescritos com os que estão sendo encaminhados. Vale ressaltar que $100 \%$ dos preparos das quimioterapias e nutrições parenterais do hospital são realizadas pelo mesmo farmacêutico, o que impossibilita que este realize a conferência de todos os medicamentos dispensados.

Segundo o NCCMERP, existem várias maneiras de se conferir a adequação da prescrição antes do medicamento ser dispensado e fornecido ao paciente, são elas: uso de códigos de barra, sistemas computadorizado, disponibilidade de dados que tracem o perfil do paciente e, se possível, uma segunda pessoa deve realizar uma checagem independente, avaliando, assim, a precisão do processo de dispensação (ASHP, 1996; NCCMERP, 1999).

Há relatos que a dupla conferência na dispensação dos medicamentos, neste hospital, é realizada por 02 técnicos de farmácia, porém as observações mostraram que $19,4 \%$ dos problemas identificados se referiram à inexistência de dupla conferência.

Identificamos, ainda, que o técnico em farmácia, ao pegar o medicamento no escaninho, na maioria das vezes, lê apenas o nome que se encontra na etiqueta de identificação da casela, não conferindo com o nome que está no rótulo do frasco ou ampola adquirido, fato que pode desencadear dispensa de medicamento errado. Isso reforça a necessidade de conferências por automatização ou por farmacêuticos antes do envio dos medicamentos. 
O Instituto Americano de Medicina relata que estudo feito em 1999 por farmacêuticos de Massachusetts - EUA estimou que 2,4 milhões de prescrições por ano são dispensadas inadequadamente em hospitais (KOHN et al., 2001).

O uso adequado dos medicamentos não depende apenas de uma prescrição de qualidade, é também fruto de dispensação responsável. No entanto a interação entre paciente/médico/farmacêutico possibilita a emergência de expectativas, demandas e troca de informações que terão conseqüências diretas no resultado da terapêutica (PEPE \& CASTRO, 2000).

A seguir, discutiremos e analisaremos os dados que identificam o processo de administração de medicamentos.

6.2.3. Problemas identificados no processo de administração de medicamentos

O processo de administração de medicamentos baseia-se no recebimento da medicação, no preparo, na administração, propriamente dita, e no monitoramento do paciente. Os erros mais comuns que ocorrem neste processo estão relacionados a paciente errado, dose errada, diluição errada, freqüência errada, omissão, método ou via errada, administração de medicamento não-prescrito ou dose duplicada do medicamento (LEAPE et al., 1995; BUENO et al., 1998; CASSIANI, 2000b; VAN DEN BEMT, 2000). Como o sistema de medicação é inter-relacionado, um erro que ocorre na administração de medicamentos pode ter sido originado em um processo anterior, seja na prescrição ou na dispensação de medicamentos (SCHNEIDER \& GIFT, 1998). 
Nesse caso, cabe ao enfermeiro o planejamento das ações de enfermagem concernentes ao processo de administração de medicamentos, seja disponibilizando recursos materiais adequados e seguros, seja capacitando a equipe de enfermagem ou promovendo condições tanto ambientais como de trabalho adequadas para o desempenho das atividades, garantindo segurança para o paciente (BOHOMOL, 2002).

O fato de a enfermagem atuar no último estágio que o medicamento percorre, antes de ser ministrado ao paciente, aumenta a responsabilidade da equipe de enfermagem, pois ela é a última oportunidade de interceptar e evitar um erro cometido nos processos iniciais. Estudo de Leape et al. (1995) identificou que a enfermagem intercepta $86 \%$ dos erros na medicação provindos dos processos de prescrição, transcrição e de dispensação, ao passo que apenas 2\% dos erros na administração são interceptados, muitas vezes, pelo paciente conhecedor de sua terapia medicamentosa. É, então, de responsabilidade da equipe de enfermagem promover a terapia medicamentosa indicada e proteger o paciente, que está sob seus cuidados, de erros na medicação e lhe fornecer informações e conhecimentos sobre os medicamentos que está utilizando, estimulando-o a participar como mais uma barreira contra possíveis erros, além de capacitá-lo com isso para seu autocuidado (PEPPER, 1995).

Um dos problemas encontrados nas clínicas abastecidas por doses individualizadas é que, apesar de não haver estoque formalizado, não há procedimentos rigorosos para evitar que a enfermagem estoque medicamentos na clínica. No hospital do estudo, a devolução dos medicamentos não utilizados pelos pacientes é feita de maneira informal, quando o mensageiro passa nas clínicas. 
Estocar medicamentos na unidade é um fator potencial de erro na medicação e acarreta alguns problemas, como: perda do medicamento por armazenamento em condições inadequadas, por vencimento da data de validade, por contaminações microbiológicas e/ ou químicas, perigo do medicamento ser utilizado em outro paciente, por engano; além de permitir desvios (RIBEIRO, 1991). Portanto, a devolução de medicamentos à farmácia é importante para eliminar a oportunidade de o paciente receber uma dose ou um medicamento errado (ATKINS \& BARONE, 1998).

Nas clínicas, atualmente, não são utilizadas tecnologias como leitura óptica de códigos de barras para controle dos medicamentos administrados aos pacientes, estratégia já implementada em muitas instituições americanas, como forma de obter informações no momento da administração de medicamentos a respeito do paciente e da terapia medicamentosa prescrita, possibilitando a identificação do paciente e a certeza do tratamento (KOHN et al., 2001)

Problemas no preparo de medicamentos

Os dados indicaram que o principal problema no processo de administração de medicamentos (46,8\% dos relatos) diz respeito à etapa de preparo dos medicamentos.

Como já relatamos anteriormente, nesta clínica todos os medicamentos são preparados por um ou dois profissionais de enfermagem (técnicos ou auxiliares de enfermagem) para posteriormente serem administrados aos pacientes por outros profissionais de enfermagem responsáveis pelas enfermarias. Esta questão é 
polêmica, pois a enfermagem tem a orientação de nunca aplicar medicamentos que não preparou, a menos que tenham sido preparados na farmácia em doses prontas pelo SDMDU (SKELLEY, 1977; CASSIANI, 2000a). Não há dúvidas quanto às vantagens e benefícios do preparo implantado na clínica, no que concerne à otimização do espaço de preparo, que pode ficar tumultuado considerando-se o tamanho da mesma (68 leitos distribuídos em 12 enfermarias) e ao melhor aproveitamento e economia de medicamentos, mas devemos garantir que aqueles profissionais estejam capacitados para exercer esta atividade.

A enfermagem pode ocasionar erros sérios no preparo de medicamentos quando não está desenvolvendo essa prática há muito tempo (TAXIS \& BARBER, 2003). Quanto aos profissionais da sala de preparo, estes seguem escala e sofrem rodízio dentro da equipe, fato que pode comprometer a qualidade e a segurança do preparo, quando assume o posto um funcionário desatualizado e destreinado, conforme relato a seguir:

"O mensageiro da farmácia chega. A técnica pede que ele a compreenda, pois há tempo não é escalada na medicação”.

Para o preparo de todos os medicamentos da clínica, o profissional escalado no PM (Posto de Medicação) utiliza pequenas etiquetas auto-adesivas preenchidas pelos profissionais de enfermagem do turno anterior. Nas etiquetas, colocam o nome dos medicamentos, as dosagens, os horários, as vias e os números do leito dos pacientes, conforme as prescrições. Considerando que estes profissionais responsáveis pela confecção das etiquetas são de seis a oito por turno, o responsável 
pela preparação fica sujeito a executar erros talvez já cometidos por um desses profissionais, anteriormente.

Ressaltando o fato de que nessa clínica um transcreve, outro prepara e outro administra, o processo de medicar sofre múltiplas transferências de informações e pedidos que vão de uma mão à outra, o que Leape et al. (2000) chamam de handoffs, e que pode ser uma fonte de erros na medicação.

Sabemos que é usual a utilização pela enfermagem de cartões de medicações, nos quais são transcritas as prescrições de medicamentos, porém sabemos também, da importância da leitura da prescrição de medicamentos com a finalidade de assegurar que o medicamento separado e preparado seja realmente o prescrito para o paciente (CASSIANI, 2000a).

Quanto às etiquetas, vale ressaltar que nelas não constam os nomes dos pacientes, e o número do leito não é um dado suficiente, pois trocas de leito e de enfermaria ocorrem com freqüência. Em relação às condições de avaliação da terapia medicamentosa, o profissional de enfermagem, nesta forma de processo, tem em seu poder apenas uma etiqueta, ao contrário do profissional da farmácia que ao preparar os medicamentos no SDMDU baseia-se na cópia da prescrição, não podendo assim detectar problemas, avaliar restrições hídricas, suspensão de medicamentos, preparos para exame ou jejum, fatores que podem interferir na administração do medicamento (LAGANÁ et al., 1989).

No que diz respeito às falhas na segurança durante a administração de medicamentos, verificamos que inúmeros medicamentos de uma ou de até duas enfermarias são colocados na mesma bandeja, fato que contradiz a orientação de que ao utilizar bandejas para levar o medicamento até o paciente deve-se atender a um 
paciente por vez, pois a diversidade de medicamentos e a quantidade de pacientes diferentes em um mesmo lugar aumentam a probabilidade de erros referentes à troca de medicamentos (CASSIANI, 2000a).

No que concerne à segurança para realização da técnica de preparo dos medicamentos, observamos falhas em obediência às normas de biossegurança, como lavagem de mãos, higiene, desinfecção de frascos/ampolas e autoproteção na quebra das mesmas.

A seguir, transcreveremos alguns relatos sobre realização de procedimentos sem lavagem de mãos e sem higiene:

“A funcionária do PM está muito gripada, com coriza (não usa máscara), limpa o nariz com uma toalha de rosto que é colocada na bancada onde dilui as medicações (não lava as mãos)”.

“..inicia a diluição, a técnica de enfermagem usa sapato fechado, cabelo preso e sem máscara, não faz lavagem das mãos”.

"Não usa algodão para quebrar ampola, não faz desinfecção da tampa do vidro de Keflin R”.

Durante a terapêutica medicamentosa é imprescindível que a equipe de enfermagem esteja preocupada, dentre outras coisas, com a manutenção dos princípios de assepsia garantindo que os artigos críticos (seringas, agulhas, soluções injetáveis, material para inalação etc) e semicríticos (medicamentos orais, sondas para medicação por via nasogástrica etc) estejam livres de microorganismos prevenindo, assim, infecções cruzadas.

Outro problema identificado refere-se ao atendimento nos horários padronizados pela clínica, pois devido ao grande volume de medicamentos prescritos 
o preparo deve iniciar-se aproximadamente duas horas antes do horário da administração dos medicamentos, caso não haja intercorrências, como atrasos da entrega dos medicamentos pela farmácia. O preparo antecipado pode comprometer a estabilidade do produto, e isso ocorre quando o profissional não é capacitado ou bem orientado quanto a este item.

Em uma clínica com aproximadamente 70 leitos, é impossível ministrar todos os medicamentos no mesmo horário, portanto é aceitável que sejam administrados meia hora antes ou depois do horário determinado, desde que esta seja norma na instituição. Porém, com intuito de minimizar este problema, deve-se evitar que os aprazamentos padronizados sejam fixados para um mesmo horário sobrecarregando o preparo e a administração de medicamentos.

Problemas detectados na administração de medicamentos

No item administração de medicamentos também encontramos alguns problemas, que corresponderam a 31,9\% dos resultados das observações, sendo o principal as falhas nas normas de biossegurança quando os profissionais não utilizaram luvas para punção venosa, reencaparam agulhas e não realizaram a lavagens de mãos antes e após a administração dos medicamentos e, principalmente, entre um paciente e outro.

"Não houve em nenhum momento a lavagem das mãos por parte do funcionário".

"Foi observado que a funcionária lavou as mãos só no início das medicações, não lavou no intervalo de um paciente para outro”. 
"O profissional não usou luvas para administrar medicamento EV e não fez a lavagem de mãos de um paciente para outro”.

A lavagem de mãos, o uso de luvas e orientações para não realizar o reencape de agulhas são princípios básicos referentes ao cuidado do paciente, sendo os mesmos encontrados em toda literatura específica (SKELLEY, 1977; LAGANÁ et al., 1989; CASSIANI, 2000a, CHÁVEZ et al, 2000).

Em relação à execução de demais tarefas, durante a administração de medicamento, identificamos que os profissionais aproveitam o momento da medicação para aferirem os sinais vitais. Se isto ocorresse com apenas um paciente, enquanto o soro está sendo infundido, por exemplo, não haveria problemas, porém isto ocorre em uma enfermaria com seis leitos. Coloca-se termômetro em 2 ou três pacientes, administra-se um medicamento, volta para recolher os termômetros e fazer o registro dos dados. Estas ações, possivelmente, tiram a atenção e o cuidado em relação aos medicamentos, podendo acarretar erros de troca de medicamentos, troca de pacientes já que na mesma bandeja, como já comentamos anteriormente, acomodam os medicamentos de todos os pacientes de até duas enfermarias.

“... inicia a administração,... ela verifica $a$ PA $\quad e \quad a$ temperatura...”.

"A técnica dá o medicamento e verifica a PA, FC e temperatura... a funcionária confere os medicamentos na prescrição de outro paciente...".

Quanto à relação entre o profissional e o paciente, as observações identificaram ainda o desconhecimento de alguns profissionais para o fato de o 
paciente usar ou não medicamentos próprios, informação que deve ser colhida junto ao paciente. Também identificamos que não explicam a ele que tipo de medicamento está tomando e a finalidade do mesmo, e administram o medicamento sem falar com o paciente, chamando-o, no máximo, pelo nome.

"Quando é medicação EV, ela fala:”seu João vou fazer uma injeção no senhor, tá?”.

“... não conversou com o paciente, chegou e fez a medicação $E V ”$.

É de extrema importância o papel de educadora que a enfermagem detêm, desse modo ela não pode prescindir da oportunidade de orientar e instruir o paciente sobre qual medicamento está consumindo, por que está tomando aquele medicamento, quais os efeitos esperados e os que necessitam de sobreaviso. É direito do paciente conhecer ainda o aspecto (cor e formato) dos medicamentos que está recebendo e a freqüência com que será ministrado. Também os pacientes devem ser solicitados a informar sobre as possíveis alergias e a atuar como parceiros nesse processo (KOHN et al., 2001).

O aprazamento dos horários para administração dos medicamentos não segue uma padronização estipulada pelo hospital ou sistema de medicação e, sim, a uma padronização estabelecida pela unidade de internação. Na unidade de clínica médica, a freqüência e seus respectivos horários são: 1x ao dia: às 14:00h; 2x ao dia: ás 10:00h e 22:00h; 3x ao dia: às 14:00h, 22:00h e 06:00h e 4x ao dia: 10:00h, 16:00h, 22:00h e 04:00h. 
Apesar de haver padronização nos horários, os dados na clínica estudada mostraram alguns problemas nos aprazamentos, quanto a estarem ou não completos, legíveis, sem rasuras e corretos, conforme relatos abaixo:

"Há um horário sobre o qual há um rabisco fazendo com que não saibamos se está correto, pois a rasura deixa ilegível”.

"O aprazamento está rasurado por corretivo".

"Medicamento prescrito para às 6 h e checado à $8 h "$.

Em relação às anotações de enfermagem e relatórios de ocorrências, os resultados indicaram que $45,4 \%$ dos medicamentos não-administrados apresentavam alguma justificativa, além do círculo em torno do horário aprazado com explicações simples como "não tem” e “falta na farmácia”. Quanto às demais anotações, encontramos apenas sete observações referindo-se a medicamentos administrados em casos de dor e nenhuma referência sobre reações adversas ou erros na medicação. Verificamos, ainda, que os profissionais checavam as prescrições após a administração do medicamento, mas não as assinavam.

A enfermagem deve valorizar a sua responsabilidade quanto às anotações e registros, que permitirão uma comunicação fluente dentro da equipe como também darão oportunidade de comprovar o trabalho tão arduamente realizado por ela, mostrando o valor documental dos prontuários e de tudo que lá está registrado; perder essa oportunidade significa desvalorizar a sua própria ação.

Em uma folha de evolução médica pudemos verificar a única anotação médica encontrada: 
"Paciente referindo vômitos após uso de remédio (não sabe qual) há 4 dias, porém só se queixou hoje”.

O hospital em estudo não possui um comitê para investigação de ocorrências e incidência de erros na medicação e também não tem métodos para registros e relatórios formais de erros na medicação, atividades estas que poderiam ser desenvolvidas pelo comitê de farmácia e terapêutica existente na instituição. Este fato impede que os profissionais envolvidos no sistema de medicação recebam relatórios periódicos e fiquem cientes dos erros ocorridos na medicação.

Expostos os problemas do sistema e de seus processos, apresentaremos a seguir os tipos, causas, providências administrativas e sugestões a respeito de erros na medicação citados pelos profissionais do sistema de medicação.

6.3. Erros na medicação: tipos, causas, providências, sugestões de profissionais.

O pesquisador realizou 40 entrevistas com intuito de conhecer como os médicos, e as equipes de enfermagem e de farmácia percebem o sistema de medicação e os erros na medicação. Para tanto, estes profissionais deveriam responder a cinco perguntas sobre os tipos de erros ou potencial para erros na medicação que mais ocorrem na clínica médica; às causas dos erros na medicação; às providências administrativas tomadas na ocorrência destes erros; sugestões para evitá-los e apontarem as falhas no sistema de medicação.

As respostas obtidas identificaram que os tipos de erros mais citados pelos profissionais foram os erros relacionados à prescrição de medicamentos, que 
totalizaram $29 \%$ dos relatos. A maioria das respostas partiu da equipe de enfermagem, sendo 23 entre as 45 respostas obtidas, provavelmente porque este profissional é o que mais depende de uma prescrição completa, correta e legível, para exercer suas atividades em vários momentos de seu turno de trabalho.

Decidimos analisar a categoria erros relacionados à prescrição de medicamentos, sob dois aspectos: erros ou inadequação da prescrição e dificuldade para compreensão de letra.

Em relação aos erros ou inadequação da prescrição, 34 (21,9\%) respostas referiam-se a problemas como dosagem errada, via errada, posologia errada, diluição errada, prescrição de medicamento inadequado, fatores preocupantes, pois dessas prescrições dependem os processos seguintes e, conseqüentemente, o tratamento adequado do paciente.

A administração de medicamentos errada (36\%) e em doses erradas (35,3\%) têm sido os tipos de erros mais freqüentes cometidos na medicação, segundo estudo realizado, e estes podem ter sido cometidos já na prescrição de medicamentos (LAPOINTE \& JOLLIS, 2003).

As inadequações nas prescrições estão justificadas em 11 das 34 respostas, tendo como causas as prescrições feitas por acadêmicos de medicina (5 a ano), pessoas não-aptas a exercer essa atividade que, na maioria das vezes, copiam a prescrição anterior, cometendo erros que poderão ser perpetuados.

Apresentamos a seguir relatos abordando o problema:

"Aconteceu de ficarem 03 dias prescrevendo cabeceira elevada SC. Nem presta atenção no que está fazendo, nem lê. É uma cópia, e às vezes até uma cópia errada, porque sei lá uma insulina SC, cabeceira elevada, emenda as duas faz uma só e nem pensa no que está escrevendo”.(E) 


\begin{abstract}
"O estagiário de medicina (interno) havia prescrito uma medicação sendo cópia do dia anterior. Segundo a funcionária, ao verificar a medicação na papeleta estava escrito: Aerosol: SF 0,9\% e BITOC. Há alguns dias técnicos circulavam o horário porque não sabiam o que era BITOC. Então no dia em que esta funcionária estava na enfermaria ficou com dúvida e procurou o interno que havia prescrito. Segundo ela, quando ela perguntou que medicamento era aquele e para que servia, o interno disse que era BITOC $e$ não sabia para que servia. Então eles procuraram em prescrições anteriores (05 dias antes desse dia) e acharam que no aerosol que era BEROTEC e não BITOC”.(TE)
\end{abstract}

Em estudo realizado em dois hospitais terciários, Brigham and Women’s Hospital e Massachusets General Hospital, durante seis meses no ano de 1993, mostraram que erros de dosagem foram os mais comum (28\%), ocorrendo a maioria deles (50 de 95) no processo de prescrição (LEAPE et al., 1995).

Os médicos prescritores devem atualizar seus conhecimentos através de literaturas, consultas aos farmacêuticos, consultas a outros médicos, como também devem participar de programas de educação continuada para determinar uma terapia medicamentosa adequada ao seus pacientes, principalmente em casos de doenças ou em condições pouco comuns à sua prática (ASHP, 1993).

Em relação aos problemas de compreensão de letra, obtivemos 20\% do total de 45 erros na prescrição, que pode estar relacionado à má grafia médica na prescrição manual.

A seguir, estão algumas citações que esclarecem as dificuldades encontradas pelos profissionais durante a leitura das prescrições:

"Letra demais, letra ruim demais. Médico escreve que tem que ser artista pra saber" (TE) 
"Assim, primeiro eles acham que a gente é adivinho, porque as letras são uns garranchos e os medicamentos, principalmente antibióticos, tem uns nomes muito idênticos, cefalosolina cefalotina, você confunde mesmo. Aí é hora de ir medicação errada”. (TF)

As prescrições de medicamentos são o início de uma cadeia de ações que levarão o medicamento até o paciente, não podendo constituir um fator exarcebado para erro ou potencial para erro na medicação. A prescrição de medicamentos em sistema computadorizado, certamente, ocasionará um grande impacto na redução de erros nos medicamentos. Mudar os sistemas pelos quais os medicamentos são prescritos é uma significativa estratégia, capaz de reduzir o número de injúrias relacionadas aos mesmos (BATES, 1996).

Em relação à categoria erros relacionados ao horário, estes corresponderam a 20,6\% das respostas. Dentre 32 respostas, 17 (53,1\%) referiam-se a atrasos na dispensação e na demora da entrega do medicamento na unidade de internação pela farmácia, o que é ruim, pois atrapalha a programação e a eficiência da terapia medicamentosa.

A seguir alguns depoimentos sobre o assunto:

"Ocorre geralmente de algumas prescrições estarem assim: fazer Lasix às 10 e às 16 horas, mas às 10h a medicação ainda não chegou. Vai chegar á tarde. Então às das 10 fica sem fazer, e vai para o dia seguinte." (E)

"Atraso do medicamento porque a farmácia traz só às 15 horas. Para não sair da rotina, atrasa o medicamento.” (TE) 
Os erros relacionados ao preparo e administração de medicamentos apareceram em 13,6\% dos relatos, dentre os quase destacamos:

"Cheguei de manhã, estava o soro glicosado com o rótulo escrito nele à mão: soro fisiológico. Então foi preparado errado.” (M).

"Tem muito erro que acontece que é na via de administração.Esse também acontece. Prescreve EV, faz IM. Passa Plasil EV, acaba fazendo IM. Esse tipo de coisa acontece também”. (M).

"De medicação trocada. Ontem mesmo aconteceu com um enfermeiro que deu uma medicação intradérmica sendo que era subcutânea. A paciente disse que estava com dor, que estava doendo".(TE)

Carvalho (2000) propôs três estratégias para minimizar erros no preparo e na administração da medicação, quais sejam: cumprimento de políticas e procedimentos referentes ao preparo e à administração; educação dos profissionais e melhora na comunicação.

Em relação às políticas e procedimentos, a autora sugere: seguir os cinco procedimentos “certos”: paciente certo, horário de administração certo, dose certa, via de administração certa, e medicamento certo; ler o rótulo do medicamento três vezes; esclarecer dúvidas antes de prepará-los; identificar o medicamento preparado com o nome do paciente, enfermaria/ leito, nome do medicamento e via de administração; certificar-se da suspensão de medicamentos na prescrição médica e sobre possíveis preparos para exames ou jejum, que possam interferir .na administração dos medicamentos, uso da pulseira de identificação do paciente, assim como a identificação do leito. 
Erros relacionados à dispensação também foram citados por 12,9\% dos entrevistados e se referiram à falta e troca de medicamentos. Seguem alguns exemplos:

"Tem muitos erros assim, às vezes troca medicamento, como esses dias mesmo eu estava na medicação, no preparo, e estava prescrito Sulcafrate e foi mandado Sustrate, no lugar, totalmente diferente a posologia. Às vezes o medicamento vem errado, vem faltando dose. Às vezes está prescrito E V, vem VO”.(TE)

"A farmacêutica não aceita que tem erros. Mas assim, é ranitidina VO e vem EV e tem muito!! Esses dias veio Cipro no lugar de Maxcef. Quando o medicamento é de 12/12, é pra subir 02 comprimidos, só mandaram 01.” (AE)

Os erros mais comuns na dispensação de medicamentos envolvem doses ou formas incorretas, que podem ocorrer devido a distrações ou problemas com o ambiente de trabalho (COHEN, 2000), problemas que foram também encontrados no hospital em estudo.

Quanto às causas dos erros na medicação, os relatos responsabilizaram a falta de atenção dos profissionais como a principal causa para o erro na medicação, com uma freqüência de 27,6\% das respostas. Estas somadas às falhas individuais representaram 47,4\% das causas de erros, segundo opinião dos entrevistados.

Estudo referente a erros na medicação identificou que a falta de atenção e lapsos de memória foram os responsáveis pelas causas de erros na medicação sendo 11\% na prescrição e 12\% na administração de medicamentos (LEAPE et al., 1995).

Muitos estudos têm responsabilizado os médicos prescritores pela maioria dos erros na medicação, e dois deles indicaram que os enganos ou lapsos foram as causas mais freqüentes de erros (57\%) (DEAN et al., 2002; LAPOINTE \& JOLLIS, 2003). 
"Pra mim, deve ser falta de atenção... eu tiro por mim, na hora que estava fazendo aquilo, alguém conversou comigo ou telefone tocou... tirou minha atenção! Se não tiver com atenção naquilo, não dá!” (AE)

"Acho que é mais pressa mesmo, falta de atenção, eles olham prescrevem lá, não pensam na pessoa que vai ler depois, como é que ela vai interpretar isso".(M)

"A falta de interesse é tremenda, tremenda mesmo, a pessoa tem que ter mais interesse, ela está trabalhando com pessoas que já estão doentes e vieram para o hospital para tratar e não é justo que ela pegue uma infecção ainda”. (TF)

"Sinceramente, falta de compromisso com o trabalho, de responsabilidade, porque se tivesse interesse faria tudo corretamente, porque não precisa circular uma medicação $e$ procurar porque não tem. Esses erros acontecem por displicência”. (TE)

O que chama a atenção é o fato de os profissionais culparem a si mesmos pelos erros, deixando de lado a visão de que o sistema em que estão envolvidos pode também colaborar para sua ocorrência.

Excesso de trabalho e falta de tempo foram a terceira causa dos erros ocorridos, com 14,5\% das respostas, e estes, possivelmente, podem ser motivos que concorreram para falhas individuais e falta de atenção, tantas vezes citados pelos profissionais.

Estudo desenvolvido na Inglaterra, por farmacêuticos de um hospital-escola, identificou como causas de erros na prescrição fatores de risco, como: ambiente de trabalho, carga de trabalho, prescrição realizada ou não para o seu paciente, 
comunicação entre os membros da equipe, bem-estar físico e mental e ausência de conhecimento (DEAN et al., 2002).

Os erros na medicação podem ser causados por falta de conhecimento, más condições ambientais, materiais inadequados oferecidos ao profissional, ou por problemas pessoais que podem levá-lo à distração. Abordagens pessoais consideram que atos inseguros, como falta de atenção, negligência ou desvio de conduta sejam algumas das causas de erros (REASON, 2003).

Carvalho et al. (1999) identificaram em seu estudo fatores de risco que podem levar à ocorrência de erros na administração de medicamentos em Unidades Básicas de Saúde, tais como: falta de atenção ou distração (33,8\%), dificuldade para entender as prescrições médicas (18,2\%), falta de preparo do profissional $(9,1 \%)$, cansaço e estresse (7,8\%), negligência ou imprudência (2,6\%).

Vale salientar que os problemas administrativos e os detectados na organização da unidade em estudo surgem como a quarta causa de erros na medicação.

Dean et al. (2002) identificaram os seguintes fatores organizacionais como causas dos erros: treinamento inadequado, a baixa percepção da importância da prescrição, a hierarquia na equipe médica e a ausência de autoconsciência dos erros.

Em relação às providências administrativas tomadas na ocorrência de erros na medicação, constatamos que a maioria delas referia-se a providências voltadas para o profissional que fez o erro e não para o desenvolvimento de estratégias que visassem aproveitar esse erro e transformá-lo em aprendizado para o sistema. As orientações, advertências verbais, suspensão/demissão, relatórios e orientações corresponderam a 80,3\% das providências citadas. 
Cohen (1996) aponta que, na ocorrência de um erro na medicação, não é dada ênfase à educação e sim à punição. Lembra que isso, ao invés de ajudar a prevenir, faz com que cada vez menos os erros sejam relatados, prejudicando o conhecimento de seus fatores de risco, permitindo sua repetição uma vez que são subnotificados.

As sugestões dos profissionais para prevenção dos erros na medicação estiveram voltadas para alterações nas atitudes individuais, como estratégias mais eficazes para prevenir erros, sugestão que correspondeu a $28,3 \%$ do total das opiniões. Ao analisar os demais resultados, percebemos que mais uma vez o indivíduo foi responsabilizado pelo sucesso ou insucesso da terapia medicamentosa, pois $54,4 \%$ dos relatos referiam-se a medidas voltadas aos profissionais e não ao sistema, tais como: alterações individuais, educação continuada e aumento de supervisão, vigilância e punições.

Em um sistema que funciona nos moldes punitivos, é muito difícil que os profissionais tenham coragem de relatar seus erros, e mesmo que o fizessem não haveria ganhos para a instituição, pois eles não seriam utilizados para mudanças nos processos ou para implementação de estratégias voltadas a melhorias.

\section{As opiniões dos profissionais a respeito das falhas no sistema de} medicação possibilitaram perceber que os profissionais não têm uma visão sistêmica do problema, mas sim individualizada, cabendo a cada profissional promover a segurança do paciente, uma vez que as falhas individuais apareceram como falhas do sistema, em 27\% dos depoimentos. Este resultado mostrou-se coerente se considerarmos que, nas respostas anteriores, as questões que envolvem o indivíduo também foram mencionadas com destaque. 
As instituições devem prover um sistema seguro de medicação que objetive construir estratégias que irão auxiliar os profissionais na prevenção de erros, através de medidas que tragam facilidades para ação de medicar e dificuldades para as oportunidades de errar.

Para que práticas de segurança sejam discutidas e implementadas pela organização é necessário que seus dirigentes assumam e desenvolvam uma cultura de segurança voltada para o paciente e organizem uma equipe multidisciplinar que lidere essas discussões, buscando analisar e avaliar cada processo existente, em busca de melhorias. 


\section{SUGESTÕES PARA MELHORIAS NO SISTEMA DE} MEDICAÇÃO DO HOSPITAL EM ESTUDO.

As organizações de saúde que queiram desenvolver um sistema que forneça um tratamento seguro ao paciente devem focalizar seus esforços e estratégias na medicação, por ser esta a causa mais comum de eventos adversos, muitos dos quais evitáveis; para este fim, existem muitos trabalhos científicos e ferramentas já desenvolvidas para prevenção de erros.

Considerando que a medicação está ligada a um sistema, o Instituto Americano de Medicina sugeriu algumas práticas que devem ser implantadas com a intenção de reduzir ou prevenir erros nos processos de medicação, visando a melhorias na segurança, quais sejam:

Adoção de uma abordagem sistêmica para identificação, redução e prevenção dos erros na medicação (mudanças na equipe, introdução de novas tecnologias, adoção dos cinco princípios para promoção de um cuidado seguro como: produzir lideranças; respeitar os limites humanos ao desenhar os processos, manter uma equipe efetiva trabalhando, antecipar o inesperado, criar um ambiente de aprendizagem); rastrear e analisar os dados sobre os erros e utilizá-los para modificar os processos e prevenir futuras ocorrências. 
- $\quad$ Padronizar as prescrições escritas e fixar regras (padronizar ou mesmo evitar as abreviaturas; utilização do sistema métrico e os zeros iniciais devem sempre preceder a expressão decimal menor que um);

- $\quad$ Limitar os tipos diferentes de equipamentos (ex: bomba de infusão);

- $\quad$ Implementar a prescrição por sistema computadorizado;

- Utilizar software farmacêutico, como fonte de informação sobre medicamentos e de checagens das prescrições;

- Implementar a dose unitária como sistema de distribuição de medicamentos;

- $\quad$ Manter na farmácia central o estoque de medicamentos intravenosos de alto risco;

- Utilizar procedimentos especiais e protocolos escritos para uso de medicamentos de alto risco (guias, checklist; double-checks; embalagens especiais; etiquetas especiais e educação);

- $\quad$ Não armazenar soluções concentradas de medicamento perigoso nos postos de enfermagem. Ex: cloreto de potássio;

- Garantir a viabilidade de suporte técnico de farmacêuticos nas decisões críticas a respeito da terapia medicamentosa;

- $\quad$ Incluir um farmacêutico nas unidades de internação para colaborar com médicos e equipe de enfermagem e servir como mais uma fonte de informação sobre medicamentos;

- Manter informações pertinentes próximas dos locais de internação (considerar o uso de máquina de leitura e código de barras no processo de 
administração de medicamentos; colocar idade e peso do paciente nas prescrições; melhorar acesso às informações; anotações sobre alergias);

- $\quad$ Educar o paciente, fornecendo-lhe informações sobre seu tratamento.

O JCAHO faz algumas recomendações gerais para prevenção de erros: reduzir a confiança na memória; aperfeiçoar o acesso a informações seguras e confiáveis sobre medicamentos; introduzir sistemas que eliminem ou diminuam a possibilidade de erro (ex: equipo de nutrição enteral que não conecte em cateter intravenoso); buscar a padronização e promover treinamentos (BATES, 1998).

Percebemos que a maioria das estratégias está voltada ao sistema, e sabemos que prevenir erros através de abordagens voltadas para os indivíduos que os cometem, é contraproducente, pois tais estratégias podem encorajar o funcionário a esconder os erros com medo das possíveis punições e da exposição a que estará sujeito.

No Brasil, estas práticas ainda são incipientes e apenas algumas foram implementadas em um número pequeno de hospitais, como a prescrição em sistema computadorizado, distribuição de medicamentos por dose unitária.

As propostas sugeridas neste estudo para o hospital analisado estarão pautadas basicamente nos parâmetros indicados pela Joint Commission on Accreditation of Healthcare Organizations - JCAHO (COUSINS, 1998), no relatório do Institute of Medicina (KOHN et al., 2001), no Manual Brasileiro de Acreditação Hospitalar (ORGANIZAÇÃO NACIONAL DE ACREDITAÇÃO, 2001) e na opinião da pesquisadora.

A proposta central é que mudanças sejam feitas com a intenção de se construir um sistema de medicação seguro, no hospital do estudo, devendo as 
mesmas começarem por pequenos passos ou por algumas etapas dos processos, minimizando o número de etapas ou melhorando a confiança de cada uma delas, tornando-as mais eficientes e, portanto, mais eficazes. Toda a melhoria requer mudanças, mas nem todas as mudanças resultam em melhoria, por isso devemos identificar as mudanças que, provavelmente, resultarão em melhoria.

Apresentaremos sugestões específicas, referentes aos problemas identificados na clínica médica e na farmácia do hospital estudado, para o sistema de medicação e também para cada um de seus processos, em particular, baseadas em propostas de implementação a serem desenvolvidas a curto, médio e longo prazos.

\section{a) Curto Prazo}

- $\quad$ A criação de uma comissão multidisciplinar, integrada por médicos enfermeiros e farmacêuticos envolvidos com os aspectos da segurança de pacientes, deve objetivar o desenvolvimento de um sistema com elos fortes e interligados e com um fluxo de informações mais consistente e eficiente. O comitê de farmácia e terapêutica já existente pode ser o responsável pela formação desse comitê, que deverá propiciar o fornecimento de medicamentos com segurança e também prevenir os eventos adversos ao medicamento.

- $\quad$ Manual que contenha as interações medicamentosas e as estabilidades dos medicamentos, disponíveis a todos os profissionais envolvidos na medicação, em todas as salas de preparo.

- Elaboração de relatórios de ocorrências específicos para eventos adversos aos medicamentos, a fim de se construir um banco de dados com informações valiosas para a transformação dos erros em melhorias para o sistema. 
- Mudança na cultura de erros, de forma que as providências administrativas não sejam voltadas à punição dos profissionais.

- Padronizar a maneira de prescrever os nomes dos medicamentos (genérico, principio ativo ou comercial), assim como a forma da dose sem uso de decimais.

- $\quad$ Evitar as abreviaturas e promover padronização daquelas que poderão ser utilizadas, divulgando-as através de treinamento a todos os profissionais envolvidos.

- Garantia de um espaço específico e padronizado na folha de prescrição para anotações de alergias aos medicamentos; e acessíveis a todos os profissionais.

- Os internos devem fazer a prescrição de medicamentos quando acompanhados de profissional médico responsável.

- $\quad$ Desenvolver um trabalho de orientação e conscientização junto à equipe médica, quanto à importância da prescrição de medicamentos e da sua legibilidade para a segurança dos pacientes.

- A farmácia deve melhorar as condições de comunicação com as clínicas, atualizando-as em relação aos medicamentos que estão disponíveis e em falta naquele local e aos medicamentos incluídos e excluídos na padronização. Dessa forma, os médicos e a enfermagem não necessitariam telefonar a toda hora para saber quais medicamentos poderão ser prescritos, evitando que o paciente deixe de receber um medicamento prescrito por estar em falta. 
- Criar condições para que os profissionais não sejam interrompidos e distraídos durante as atividades de prescrição, dispensação, preparação e administração de medicamentos, seja por telefone, televisão ou conversas.

- Que duas pessoas preparem os medicamentos, evitando antecipar o preparo, garantindo, assim, a estabilidade dos medicamentos e a possibilidade de conferência do medicamento preparado.

- $\quad$ Diminuir o número de medicamentos por bandejas, disponibilizando, de preferência, uma para cada paciente.

- Diminuir o rodízio entre os profissionais do posto de preparo e promover treinamento constante dos que lá se encontram.

- $\quad$ Disponibilizar as prescrições durante o preparo dos medicamentos. Nesse caso, talvez devessem conter três vias, ficando uma anexa à papeleta, outra na farmácia e a última no posto de preparo.

- Maior controle dos psicotrópicos e dos medicamentos que não são usados pelos pacientes, com consecutiva devolução destes à farmácia.

- Colocar os nomes dos pacientes nos medicamentos preparados, além de pulseiras de identificação em todos eles. Também é necessário educar os profissionais para fazerem as consultas antes de administrar a medicação, confirmando, assim, se os dados dos pacientes estão compatíveis com os dos medicamentos prescritos e preparados.

- A enfermagem deve ter condições de fornecer aos pacientes informações a respeito dos medicamentos administrados (o quê, para que, quando, como, o que fazer), fazendo com que eles participem de seus tratamentos e estejam cientes dos sinais e sintomas que possam vir a apresentar e as condutas que devem 
tomar, nesse caso. É importante também que o paciente esteja preparado para utilizar os medicamentos em casa, com segurança.

- A enfermeira deve estar mais próxima de seus funcionários nesses momentos, conferindo as prescrições para alergias, interações medicamentosas etc.

- Montar um grupo de enfermagem para discutir as questões referentes aos medicamentos na instituição.

\section{b) Médio Prazo}

- $\quad$ As etapas apresentadas no fluxograma devem ser revistas e analisadas por uma equipe multidisciplinar, constituída com intuito de diminuir o número de passos, os re-trabalhos existentes e de realizar o planejamento de um sistema mais simples, mais eficiente e seguro.

- Criar o Centro de Informações sobre Medicamentos para fornecer informações, suporte técnico, análise de reações adversas e interações medicamentosas e ensino aos profissionais.

- $\quad$ Fornecer cursos para todas as categorias profissionais envolvidas na medicação, sobre os diversos tipos de erros e as formas de minimizá-los.

- Todos os médicos ingressos na residência devem passar por treinamento a respeito dos cuidados com a prescrição de medicamentos. Devido ao pequeno número de farmacêuticos contratados no hospital do estudo e considerando ser este um hospital ligado à universidade, poderia haver um intercambio entre ele e a faculdade de farmácia, para que esta fosse responsável por esse treinamento. 
- Os profissionais escalados para realização do preparo dos medicamentos devem ser devidamente qualificados, recebendo treinamento prévio sobre as questões de segurança no preparo.

- A enfermagem deve receber constantes treinamentos sobre medicamentos lançados no mercado e adicionados à lista de padronizados, como também sobre as interações medicamentosas, reações, instabilidades etc.

- Que o ambiente destinado à prescrição de medicamentos seja alterado, criando-se um lugar próprio para este fim. Além de reservado deve ser tranqüilo, para que os médicos possam consultar DEF, livros e manter contato com farmacêuticos, por telefone.

- $\quad$ Realizar reestruturação física da farmácia, a fim de que ela fique mais organizada, tenha melhor disposição dos móveis e materiais na área de dispensação. Evitar também interromper os profissionais durante suas atividades, possibilitando menor risco de erro.

\section{c) Longo prazo}

- Implantação da prescrição por sistema computadorizado.

- $\quad$ Implantação da dose unitária.

- Controle de estoques e de dispensação por códigos de barra.

- $\quad$ Aumento do quadro de pessoal capacitado e treinado, principalmente de farmacêuticos. 


\section{CONCLUSÕES}

Analisar o sistema de medicação e os processos que nele são desenvolvidos permitiu que identificássemos pontos de fragilidade no que diz respeito à segurança do paciente na medicação.

Os resultados deste trabalho permitiram concluir que a instituição deve centrar seus objetivos num sistema de medicação seguro aos pacientes, utilizando, para este fim: diminuir a confiança na memória dos profissionais; mudança na cultura dos erros; melhorar treinamento; simplificar e padronizar os processos e as atividades neles desenvolvidos; melhorar o acesso a informações e às comunicações diretas; informatização do sistema, se necessário; melhorar o ambiente de trabalho e introduzir avaliações imediatas sobre as ações executadas.

Através da análise dos dados chegamos às seguintes conclusões:

- O processo de prescrição de medicamentos comporta características e falhas que pode facilitar a ocorrência de erros, como: confecção manual da prescrição, falta de dados, permissão para abreviaturas e nomes genéricos e comerciais, ambiente desfavorável e falta de informações atualizadas.

- O processo de dispensação e distribuição de medicamentos possui pontos frágeis, dentre os quais estão: ambiente inadequado, falta de conferências adequadas, falta de pessoal. 
- O processo de administração de medicamentos apresenta falhas na técnica; na segurança do paciente; além do que o profissional executa várias atividades ao mesmo tempo durante a medicação; falhas na comunicação com o paciente.

- Parece não haver entre os profissionais a consciência de que o sistema de medicação pode auxiliar na prevenção ou na ocorrência dos erros, dependendo de como este está estruturado. Os profissionais concentram a visão dos erros nos indivíduos, podendo este fato refletir a cultura transmitida por seus chefes e pela própria instituição.

Outras conclusões a que chegamos, além das já expostas neste item e na discussão:

- O estudo possibilitou a percepção da dinâmica das rotinas dos profissionais, conscientizando-nos sobre a existência de falhas e problemas dos processos, bem como permitiu a percepção do caminho a ser percorrido para resolução das questões simples, como melhoria na comunicação e na relação profissional-profissional e profissional-paciente.

- Os profissionais e as equipes não estão trabalhando de maneira interdisciplinar e transdisciplinar na segurança do paciente, no que diz respeito à medicação.

- Os profissionais de saúde precisam estar cientes que relatar um erro cometido pode ser uma estratégia de prevenção, considerando-se que podemos aprender com os erros dos outros, sem a necessidade de passar pelas mesmas circunstâncias expondo a si, ao paciente e a instituição de saúde. Acreditamos que os benefícios oriundos deste estudo possam se estender à instituição em questão, através 
da utilização dos conhecimentos adquiridos na identificação e análise realizada do sistema de medicação vigente.

Os profissionais e acadêmicos envolvidos nos processos poderão visualizar os caminhos que percorrem em suas ações diárias, reavaliá-los e torná-los mais seguros para si próprios e para o paciente.

O fato deste estudo ter centralizado suas observações e entrevistas em uma clínica de internação, em especial, não foi empecilho para identificação e análise do sistema de medicação como um todo. Estudos posteriores podem abranger outras ou mais clínicas na busca incessante de informações a respeito deste tema. Acreditamos também, que, após este estudo, novas idéias surjam e venham se somar àquelas voltadas para a prevenção de erros na medicação e que já se encontram em execução, com o intuito de trazer segurança para os pacientes na terapêutica medicamentosa. 


\section{REFERÊNCIAS}

ALLAN, E. L.; BARKER, K. N. Fundamentals of medication error research. Am. J. Hosp. Pharm., v. 47, p. 555-571, Mar. 1990.

AMERICAN SOCIETY OF HOSPITAL PHARMACISTS - ASHP. Draft guidelines on preventable medication errors. Am. J. Health-System Pharm., v. 49, p. 640-649, 1992.

AMERICAN SOCIETY OF HOSPITAL PHARMACISTS - ASHP. Guidelines on preventing medication errors in hospitals. Am. J. Health-System Pharm., v. 50, p. 305-14, 1993.

AMERICAN SOCIETY OF HOSPITAL PHARMACISTS - ASHP. Top-priority actions for preventing adverse drug events in hospitals. Recommendations of an expert panel. Am. J. Health-System Pharm., v. 53, p. 747-751, 1996.

ANDERSON, J. G. et al. Evaluating the capability of information technology to prevent adverse drug events: a computer simulation approach. J. Am. Med. Inform Assoc., v. 9, n. 5, p. 479-490, 2002.

ARAUJO, L. C. G. Organização \& métodos: integrando comportamento, estrutura, estratégia. São Paulo: Atlas, 1994. 287 p.

ATKINS, P. M.; BARONE, L. D. Case study on measuring and improving the medication use system. In: Cousins DM. Medication use: a system approach to reducing errors. Oakbrook Terrace: Joint Commission on Accreditation of Healthcare Organizations, 1998. p.117-129.

BARKER, K. N. et al. Medication errors observed in 36 health care facilities. Arch. Intern Med., v.162, n. 16, p. 897-903, Sep. 2002. 
BATES, D. W. Medication errors. How common are they and what can be prevent them? Drug Safety, v. 15, n. 5, p. 303 - 310, Nov. 1996.

BATES, D. W. Preventing medication errors. In: COUSINS, D. M. Medication use: a system approach to reducing errors. Oakbrook Terrace: Joint Commission on Accreditation of Healthcare Organizations, 1998. p.57-73.

BATES, D. W. Using information technology to reduce rates of medication errors in hospitals. BMJ, v. 320, p. 788-791, 2000.

BATES, D. W. et al. Incidence of adverse drug events and potential adverse drug events: implications for prevention. JAMA, v. 274, n. 1, p.29-34, 1995.

BATES, D. W. et al. The cost of adverse drug events in hospitalized patients. JAMA, v. 277, n. 4, p.307-311, 1997.

BERTALANFFY, L. von. Teoria geral dos sistemas. Petrópolis: Vozes, 1977.

BERWICK, D. M.; LEAPE. L. L. Reducing errors in medicine. BMJ, v. 319, p. 136 - 137, Jul. 1999.

BERWICK, D. M. et al. Melhorando a qualidade dos serviços médicos, hospitalares e da saúde. Trad. de José Carlos Barbosa dos Santos. São Paulo: Makron Books, 1994. 296 p.

BOHOMOL, E. Erros de medicação: causas e fatores desencadeantes sob a ótica da equipe de enfermagem. São Paulo, 2002. 143f. Dissertação (Mestrado) - Escola Paulista de Medicina. Universidade Federal de São Paulo.

BRASIL. Ministério da Saúde. Conselho Nacional de Saúde. Resolução 196/96. Pesquisas com seres humanos. Brasília: Ministério da Saúde, 1996. 26 p.

BRENNAM, T. A. et al. Incidence of adverse events and negligence in hospitalized patients. N. Engl. J. Med., v. 324, n. 6, p. 370-376, 1991.

BUENO, E. et al. Erros na administração de medicamentos: fatores de risco e medidas empregadas. Rev. Baiana Enfermagem, v. 11, n. 1, p. 101-119, 1998. 
CABRAL, J. D. Poor physician penmanship. JAMA, v. 278, n.13, p. 1116 - 1117, 1997.

CARDELLA, B. Segurança no trabalho e prevenção de acidentes: uma abordagem holística: segurança integrada à missão organizacional com produtividade, qualidade, preservação ambiental e desenvolvimento de pessoas. São Paulo: Atlas, 1999.

CARVALHO, V. T. Erros na administração de medicamentos: análise dos relatados dos profissionais de enfermagem. Ribeirão Preto, 2000. 139f. Dissertação (Mestrado) - Escola de Enfermagem de Ribeirão Preto, Universidade de São Paulo.

CARVALHO, V. T. et al. Erros mais comuns e fatores de risco na administração de medicamentos em unidades básicas de saúde. Rev. Latino -Am. Enfermagem, v. 7, n. 5, p.67-75, dez. 1999.

CASSIANI, S. H. B. Um salto para o futuro no ensino da administração de medicamentos: desenvolvimento de um programa instrucional auxiliado pelo computador. Ribeirão Preto, 1998. 206 f. Tese (Livre Docência) - Escola de Enfermagem de Ribeirão Preto, Universidade de São Paulo.

CASSIANI, S. H. B. Administração de medicamentos. São Paulo: EPU, 2000a. $131 \mathrm{p}$.

Erros na medicação: Estratégias de Prevenção. Rev. Bras. Enfermagem, v. 53, n. 3, p. 424-430, jul/set. 2000b.

CASSIANI, S. H. B. et al. A prescrição médica eletrônica em um hospital universitário. Rev. Bras.Enfermagem, v. 55, n. 5, p. 509-513, set.- out. 2002.

CASSIANI, S. H. B. et al. Erros na medicação: A avaliação do sistema de medicação em quatro instituições hospitalares. Ribeirão Preto: EERP/USP, 2003. $123 \mathrm{p}$

CASTRO, M. S. Introdução ao estudo dos erros de medicação. Porto Alegre: Sociedade Brasileira de Farmácia Hospitalar, 2001. 
CHÁVEZ, S.,et al. Las manos de los trabajadores de la salud como factor predisponente en las infecciones nosocomiales. Rev. Enfermedades Infecc. Ped; v. 13, n. 51, p.353-8, mar. 2000

CHIAVENATO, I. Administração: teoria, processos e prática. $2^{a}$ ed. São Paulo: Makron Books, 1994. 522 p.

CHIERICATO, C. et al. Instrumento de registro de erros nas medicações segundo revisão da literatura. Acta Paul. Enfermagem, v. 12, n. 2, p. 79-90, 2001.

CHURCHMAN, C. W. Introdução à teoria dos sistemas. 2a ed. Petrópolis: Vozes, 1975.

COHEN, M. R. Banish a system that blames. Nursing, v. 26, n. 1, p. 15, 1996.

COHEN, M. R. Preventing medications errors related to prescribing. In: Medication errors causes, prevention, and risk management. Washington: American Pharmaceutical Association, 2000, p.8.1-8.23.

COIMBRA J. A. H. et al. Sistema de distribuição de medicamentos por dose unitária: reflexões para a prática da enfermagem. Rev. Latino - Am. Enfermagem, v. 6, n. 4, p. $15-19,1998$.

COOK, R. I. et al. A tale of two stories: contrasting views on patient safety. Chicago: National Patient Safety Foundation, 1998. Disponível em: http://www.npsf.org/exec/report.html/ Acesso em: 30 jul 2003.

COUSINS, D. D. Defining medication errors. In: Medication use: a system approach to reducing errors. Oakbrook Terrace: Joint Commission on Accreditation of Healthcare Organizations, 1998. p 39-56.

CRUZ, T. Workflow: a tecnologia que vai revolucionar processos. $2^{\mathrm{a}}$ edição. São Paulo: Atlas, 2000.

DEAN, B. et al. Causes of prescribing errors in hospital inpatients: a prospective study. Lancet, v. 359, n. 9315, p. 1373-1378, Apr. 2002. 
DRAFT guidelines on preventable medication errors. Am. J. Hosp. Pharm., v. 49, n. 3, p. 640-648, Mar. 1992.

FLYNN, E. A. et al. Comparison of methods for detecting medication errors in 36 hospitals and skilled-nursing facilities. Am. J. Health - System Pharm., v. 59, p. 436-445, May 2002.

GANDHI, T. K. et al. Identifying drug safety issues: from research to pratice. Int. J. Quality Health Care, v. 12, n 1, p.69-76, 2000.

HATFIELD, G. Rating hospitals for medications safety: a scorecard. Pharmacy Times, v. 65, n 9, p. 42-45, Sept. 1999.

HOSPITAL ISRAELITA ALBERT EINSTEIN. Manual Farmacêutico. $5^{\mathrm{a}}$ edição. São Paulo, 2001.

KELLY, W. N. Pharmacy contributions to adverse medication events. Am. J. Health-System Pharm. v. 52, p. 385-390, 1995.

KOHN, L. T. et al. (editors) To Err is human: building a safer health system. Washington: Committee on Quality of Health Care in America, National Academy of Institute of Medicine, 2001. 312 p.

LAGANÁ, M. T. C. et al. Princípios gerais de administração de medicamentos e ações de enfermagem. Rev. Esc. Enfermagem - USP, v. 23, n. 1, p. 3-16, abr. 1989.

LAPOINTE, N. M. A.; JOLLIS, J. G. Medication errors in hospitalized cardiovascular patients. Arch. Intern Med., v.163, p. 1461-1466, June 2003.

LEAPE, L. L. Error in medicine. JAMA, v. 272, n. 23, p.1851-7, Dec. 1994.

LEAPE, L. L. et al. Systems analysis of adverse drug events. JAMA, v. 274, n.1, p. 35-43, July 1995.

LEAPE, L. L. et al. Reducing adverse drug events: lessons from a breakthroughs series collaborative. Jt. Comm. J. Qual. Improv., v. 26, n. 6 p. 321-331, 2000. 
LEE, P. Ideal principles and characteristics of a fail-safe medication-use system. Am. J. Health-System Pharm., v. 59, n. 4, p. 369-371, 2002.

LESAR, T. S. et al. Medication-prescribing errors in a teaching hospital. A 9-year experience. Arch. Intern Med., v. 157, n. 14, p. 1569-1576, 1997.

LYONS, R. et al. Legibitity of doctors' handwriting: quantitative comparative study. BMJ, v. 317, n. 7162, p. 863-864, 1998.

LOBIONDO-WOOD, G.; HABER, J. Pesquisa em Enfermagem: métodos, avaliação crítica e utilização. Trad. Ivone Evangelista Cabral. $4^{a}$ edição. Rio Janeiro: Guanabara Koogan, 2001. 330 p.

MADALOSSO, A. R. M. Iatrogenia do cuidado de enfermagem: dialogando com o perigo no quotidiano profissional. Rev. Latino - Am. Enfermagem, v. 8, n. 3, p. 11 -17 , jul 2000.

MALUVAYSHI, C. H.; SANTOS, J. A. S. A qualidade da dispensação com o sistema de dose unitária. In: CASSIANI, S. H. B.; UETA, J. A segurança dos pacientes na utilização da medicação. $1^{\text {a }}$ edição. São Paulo: Artes Médicas, 2004. p. $85-91$.

MELO, I. S. Sistemas de informação. 3ª ed. São Paulo: Saraiva, 1987.

MIASSO, A. I.; CASSIANI, S. H. B. Erros na administração de medicamentos: divulgação de conhecimentos e identificação do paciente como aspectos relevantes. Rev. Esc. Enfermagem - USP, v. 34, n. 1, p. 16-25, mar. 2000.

MINDEN, V. Improvement tip: Only two was to improve a process. Disponível em: www.qualityhealthcare.org Acesso em: 25 maio 2003.

NADZAN, D. M. A system approach to medication use. In: Cousins DM. Medication use: a system approach to reducing errors. Oakbrook Terrace: 1998. p. 5-18. 
NATIONAL COORDINATING COUNCIL FOR MEDICATION ERROR REPORTING AND PREVENTION: COUNCIL RECOMMENDATION.

Recommendations to correct error-prone aspects of prescription writing. Adaptado em $\quad$ Sept. 4, $1996 \quad$ Disponível em <http://www.nccmerp.org/council/council1996-09-04.html> Acesso em: 21 jul. 2003.

NATIONAL COORDINATING COUNCIL FOR MEDICATION ERROR REPORTING AND PREVENTION. NCCMERP Taxonomy of medication errors. NCCMERP, $1998 . \quad$ Disponível em <http://www.nccmerp.org/public/aboutmederror.html> Acesso em 10 fev. 2003

NATIONAL COORDINATING COUNCIL FOR MEDICATION ERROR REPORTING AND PREVENTION: COUNCIL RECOMMENDATION. Recommendations for Avoiding Error-Prone Aspects of Dispensing Medications Adaptado em $\quad$ March 19, 1999 Disponível em <http://www.nccmerp.org/council/council1999-03-19.html> Acesso em: 21 jul. 2003.

ORGANIZAÇAO NACIONAL DE ACREDITAÇÃO - ONA, Manual Brasileiro de Acreditação, 2001. Disponível em: http://www.ona.org.br/ Acesso em: 30 jun. 2003.

OSBORNE, J. et al. Nurses' perceptions: when is it a medication error? J. Nurs. Admin., v. 29, n. 4, p. 33-38, 1999.

PEPE, V. L. E.; CASTRO, C. G. S. A interação entre prescritores, dispensadores e pacientes: informação compartilhada como possível benefício terapêutico. Cad. Saúde Pública, v. 16, n. 3, p. 815 - 822, jul .- set. 2000.

PEPPER G. A. Errors in drug administration by nurses from Understanding and Preventing Drug Misadventures Conference. Am. Soc. Health-System Pharm., v. 52, n. 4, p. 390 - 395, 1995.

PEREIRA, M. S. et al. Avaliação de serviços de apoio na perspectiva do controle de infecção hospitalar. Rev Eletrônica Enfermagem, v. 1, n. 1, out - dez. 1999. Disponível em: <http://www.fen.ufg.br/revista > Acesso em: 10 fev. 2003.

PHARMACY-NURSING shared vision for safe medication use in hospitals: executive session summary: Bethesda, Maryland Dec, 2002. Am. J. Health-System Pharm., v. 60, n. 10, p. 1146-1052, may 2003. 
PHELAN, G. et al. Self -administration of medication by patients and family members during hospitalization. Patient Educ. Couseling, v. 27, p. 103-112, 1996.

POLIT, D. F.; HUNGLER, B. P. Fundamentos de Pesquisa em Enfermagem. Trad. Regina Machado Garcez. 3ª ed. Porto Alegre: Artes Médicas, 1999. 391 p.

REASON, J. Human error. Cambridge, M.A.: Cambridge University Press, 2003. 301p.

RIBEIRO, E. Dose Unitária - Sistema de distribuição de medicamentos em hospitais. São Paulo, EAESP/FGV, 1991. 476 f. Dissertação (Mestrado em Administração Hospitalar e de Sistemas de Saúde). São Paulo: Fundação Getúlio Vargas.

ROCHA, L. L. Organização e métodos: uma abordagem prática. $6^{\mathrm{a}}$ ed. São Paulo: Atlas, 1987. 286 p.

SABBATINI, R. Farmácia Eletrônica. Jornal Correio Popular, Campinas, 31/3/1998.

SKELLEY, E. G. Medicação e matemática na enfermagem. Trad. Equipe Associação Alumni. São Paulo: EPU, 1977. 297 p.

SCHNEIDER, P. J.; GIFT, M. Measuring and monitoring the performance of the medication use system. In: COUSINS, D. D. Medication use: a systems approach to reducing errors. Oakbroak Terrace: Joint Commission on Accreditation of Healthcare Organizations, 1998. p. 19-37.

SOUZA, M. S. M. Ativos microencapsulados encontram mais aplicações. Disponível em: <http://www.quimica.com.br/revista/qd388/microencap1.htm> Acesso em: 4 nov. 2003.

TAXIS, K.; BARBER, N. Ethnographic study of incidence and severity of intravenous drug errors. BMJ, v. 326, n. 7391, p. 684-687, mar. 2003. 
UETA, J. et al. Plano de gestão para a farmácia de um hospital-escola. In: CASSIANI, S. H. B.; UETA, J. A segurança dos pacientes na utilização da medicação. $1^{a}$ edição. São Paulo: Artes Médicas, 2004. p. 64 - 72.

UNIVERSIDADE FEDERAL DE GOIÁS. Hospital das Clínicas. Guia Farmacotécnico. $2^{\mathrm{a}}$ edição. Goiânia, 2001. 47p.

VAN DEN BEMT, P. M. L. A. et al. Drug- related problems in hospitalized patients. Drug Safety, v. 22, n. 4, p. 321-333, 2000.

WEN, C. L. Aspectos sobre a prescrição computadorizada de medicamentos. São Paulo, 2000. Tese (Doutorado em Ambiente Computacional à Prática Clínica) Faculdade de Medicina da Universidade de São Paulo, São Paulo, 2000. Disponível em: <http://saudetotal.com/melanoma/index.htm> Acesso em: 10 fev. 2003.

WOMER, R. B. et al. Multidisciplinary systems approach to chemotherapy and holding the gains. J. Clin. Oncol., v. 20, n. 24, p. 4705-4712, dec. 2002. 


\section{APÊNDICE A - Instrumento utilizado na $1^{\text {a }}$ Etapa da Coleta de Dados}

Roteiro de Entrevista para identificar o sistema de medicação existente no hospital Entrevistado: profissional designado pela instituição

1. Processo de Prescrição de Medicamentos

a) A prescrição médica em 80\% do hospital é: （ ) eletrônica （ ） manual

b) Os medicamentos são prescritos usando somente o nome genérico? ( ) $\operatorname{sim}$ ( ) não

c) As abreviaturas são permitidas? ( ) sim ( ) não

d) São usados horários padronizados para medicamentos de rotina? ( ) sim ( ) não

e) A idade do paciente, peso, altura, alergias estão disponíveis no sistema / prontuário? ( ) $\operatorname{sim}$ ( ) não

f) Essas informações estão completas e atualizadas? ～( ) sim ～～～～） não

2. Processo de Dispensação e Distribuição de Medicamentos

a) A farmácia está aberta 24 horas por dia? ( ) sim ～～） não

Número de horas que permanece aberta:

b) Pelo menos $90 \%$ das doses são enviadas na forma de:

- dose individualizada ( ) $\operatorname{sim} \quad$ ( ) não

- dose unitária ( ) sim ( ) não

c) por mini-estoque, tanto nas áreas de cuidado crítico como não crítico?

( ) $\operatorname{sim}$ ( ) não

d) Os farmacêuticos fornecem informação para os profissionais a respeito de medicamentos novos ou não padronizados no hospital? （） sim （） não.

e) Pelo menos $80 \%$ da nutrição parenteral e quimioterapia, intermitentes e contínuas são infusões preparados pela farmácia ou outro serviço? ( ) sim ～（ ) não

f) Há centro de informações sobre medicamentos? ( ) sim ～（ ） não

g) O sistema da farmácia revê as prescrições médicas para avaliação de terapêutica, alergias aos medicamentos, interações e doses excessivas? （ ) sim （ ) não

h) Há dupla conferência na dispensação dos medicamentos (independente do sistema de distribuição de medicamentos)? ( ) sim （ ) não

i) Há comissão de padronização de medicamentos? ( ) sim （ ) não

j) Existem informações atualizadas sobre os medicamentos disponíveis, fornecidos pela instituição a pelo menos 90\% das clínicas? ( ) sim ～～） não

Qual tipo? 
3. Processo da Administração de Medicamentos

a) Existem procedimentos para evitar medicamentos estocados? ( ) sim ( ) não

b) São usados códigos de barras na documentação da administração de medicamentos?

( ) $\operatorname{sim} \quad$ ( ) não

c) É permitido o uso de mais de uma marca de bomba de infusão no hospital?
( ) $\operatorname{sim}$
( ) não

d) Existe estoque de medicamentos (formalizado) nas clínicas? ( ) sim ( ) não

4. Sistema de Medicação do Hospital

a) Há um comitê formal que investiga erros na medicação.? （ ) sim （ ) não Se afirmativo este comitê é composto por representantes da área: médica, farmácia, enfermagem e qualidade? ( ) sim () não . Explique

b) Há algum método disponível de relatos de erros na medicação: relatos escritos, por e-mail etc ( ) $\quad$ ( ) não

c) A farmácia, enfermagem e a equipe médica recebem relatos periódicos de erros em medicação? ( ) sim ( ) não

d) Existem diretrizes escritas para:

* o uso de medicamentos por pacientes em casa? ( ) sim （ ) não

* a auto administração de medicamentos por pacientes? ( ) sim ( ) não

* a dupla conferência do cálculo de medicamentos de alto risco? ( ) sim ( ) não

* como as prescrições são esclarecidas para os pacientes de alta hospitalar?

( ) sim ( ) não

* a administração de medicamentos endovenosos? ( ) sim （ ) não

e) Existe a devolução de medicamentos não utilizados? ( ) $\operatorname{sim} \quad$ ( ) não

f) Existem formas específicas de controle de psicotrópicos? ( ) sim （ ) não

g) Outras observações necessárias

Adaptado de HATFIELD (1999) 


\section{APÊNDICE B - Instrumento utilizado na $2^{\text {a }}$ Etapa da Coleta de Dados}

Guia estruturado de observação não-participante

Nome auxiliar de pesquisa:

Data e horário do início da observação:

Data e horário do término da observação:

Local:

Processo observado:

Etapas observadas (enumere e descreva detalhadamente cada etapa, descrevendo a situação)

Observação: Condições do ambiente, local apropriado para a finalidade (ruídos, som, mobiliário, espaço etc), tempo de execução da ação, a situação em si - descrição detalhada, as pessoas envolvidas (titulação), consequências das ações se houver. Pessoal envolvido (número, titulação, cargos). 


\section{APÊNDICE C - Instrumento utilizado na $3^{\text {a }}$ Etapa da Coleta de Dados}

Roteiro de entrevista semi-estruturada com os profissionais, residentes e acadêmicos do $5^{\circ}$ ano de medicina envolvidos nos processos de medicação.

Número da Entrevista:

Categoria profissional:

Função:

Processo em que está envolvido:

Local:

Data e hora:

1. Quais os tipos de erros relacionados à medicação que você percebe com maior freqüência nessa clínica / nesse hospital? Marque os que considera na sua resposta.

( ) Erros relacionados ao paciente. Tipos:

( ) Erros relacionados ao horário, medicamento administrado. Tipos:

( ) Erros relacionados à prescrição. Tipos:

( ) Erros relacionados a dispensação do medicamento. Tipos:

( ) Erros relacionados ao registro do medicamento. Tipos:

( ) Outros tipos

2. Na sua opinião, por que esses erros ocorrem?

3. Que providências (clínicas e/ou administrativas) são tomadas na ocorrência desses erros?
( ) relatório
( ) orientação
( ) advertência
( ) demissão
( ) suspensão
( ) outras

4. Quais as suas sugestões para evitar erros na medicação?

5. O que, no sistema de medicação*, você acredita está contribuindo para a ocorrência de erros na medicação?

\footnotetext{
* Sistema de medicação é o compreendido como o conjunto de ações percorridas para que o medicamento seja administrado ao cliente. Compreende a prescrição, requisição, dispensação e administração do medicamento. No sistema estão envolvidos os funcionários, pacientes, equipamentos, medicamentos, decisões, políticas etc.
} 


\section{APÊNDICE D - Instrumento utilizado na $4^{\text {a }}$ Etapa da Coleta de Dados}

Revisão dos prontuários médicos (papeletas diárias, relatório de enfermagem) e folhas de ocorrências.

Nome do observador

Local

Data e hora

\section{PRESCRIÇÃO MÉDICA}

1. A prescrição médica analisada é: （ ) eletrônica （ ) manual

- Se eletrônica, a impressão é perfeitamente legível?

( ) sim ( ) não ( ) em parte.

Explique:

- Se manual, a grafia é perfeitamente legível?

( ) sim ( ) não ( ) em parte.

Explique:

- Existem cópias carbonadas da prescrição?

( ) sim ( ) não ( ) em parte.

Explique:

- A grafia é legível?

( ) $\operatorname{sim} \quad$ ( ) não ( ) em parte. Explique:

2. Identificação do paciente na prescrição completa (contém: nome do paciente, leito, $\mathrm{n}^{0}$ de registro, data, nome e/ou CRM do prescritor)?

( ) $\operatorname{sim} \quad$ ( ) não Se não, o que faltou?

3. Medicamentos prescritos utilizando-se o nome:
( ) comercial
( ) do princípio ativo
( ) ambos

4. Prescrição completa (nome do medicamento, apresentação, dose, via, diluição freqüência)? ( ) sim （ ) não Se não, relate 
5. Utilização de siglas e abreviaturas na prescrição de medicamentos?

( ) sim ( ) não Se sim, dê exemplos (e o que significam):

6. Alteração ou suspensão de algum medicamento ao longo do dia?

( ) sim ( ) não Se sim, como foi feita? ( manualmente ou eletrônica)

7. Rasuras na prescrição (manual ou eletrônica)?

( ) $\operatorname{sim}$ ( ) não Se sim, comente de que tipo:

8. Data e hora atualizadas (seja para as prescrições do dia, seja para as alterações feitas)?

( ) sim ( ) não Se não, comente:

9. Aprazamento da administração dos medicamentos está
( ) correto
( ) completo
( )legível
( ) sem rasuras

Comentários:

Realizado por (profissional):

10. Padronização de horários de administração de medicamentos?

( ) $\operatorname{sim} \quad$ ( ) não Se não, como é feita?

\section{FOLHA DE ANOTAÇÕES DE ENFERMAGEM}

1. Medicamentos não administrados têm justificativa anotada (horário circulado e o motivo anotado)?
( ) $\operatorname{sim}$
( ) não
Se não, comente

2 Alguma observação relacionada à Administração de Medicamentos:
( ) $\operatorname{sim}$
( ) não
Quais e qual tipo?

3. Relatos ou anotações quanto à ocorrência de :
* Erros de via:
( ) sim
( ) não
Se sim, onde? Qual?
* Erros de prescrição: ( ) sim ～( ) não
Se sim, onde? Qual?
- Erros de dose:
Se sim, onde?Qual? 
* Troca de paciente: ( ) sim ( ) não

Se sim, onde?Qual?

ANOTAÇÕES DA OCORRÊNCIA:

NOME DO OBSERVADOR:

DATA E HORA:

FONTE:

RELATADO POR:

CARGO/FUNÇÃO:

LOCAL:

DATA E HORA:

TRANSCRIÇÃO DA OCORRÊNCIA 


\title{
APÊNDICE E - Sessão de Treinamento de Auxiliares de Pesquisa
}

\author{
Objetivo: \\ Oferecer informações com a finalidade de preparar profissionais / acadêmicos para \\ auxiliarem pesquisadores na coleta de dados, nas diversas fases de uma pesquisa.
}

\section{Metodologia:}

A capacitação dos auxiliares será desenvolvida dentro de uma carga horária de 20 horas, distribuídas em módulos teórico e prático.

\section{Clientela:}

Enfermeiros-assistenciais, enfermeiros-residentes, acadêmicos de enfermagem.

Carga Horária: 20 horas / semanais

\section{Conteúdo Programático:}

Módulo Teórico: 8 horas

* Noções sobre erros no sistema de medicação: leitura e discussão de artigos de periódicos referenciados.

* Apresentação do projeto

* Etapas de pesquisa

* Orientação sobre observação não-participante

\section{Módulo Prático: 8 horas}

Realização de um exercício prático que servirá como teste para verificação da confiabilidade interobservadores e da aptidão de cada um para a atividade de observação. Neste exercício utilizaremos projeção de um vídeo que demonstrará uma situação prática de administração de medicamentos. Durante e após esta apresentação, os auxiliares deverão fazer um relatório de observação com descrições detalhadas das situações. Para estarem aptos a exercer a atividade, deverão observar e descrever nos relatórios os itens abaixo. Apreciaremos as concordâncias ou discordâncias nas descrições relativas à situação observada do medicamento. Serão consideramos aptos aqueles auxiliares de pesquisa cujas observações atenderemm a $80 \%$ dos itens.

1. Descrição física da enfermeira

2. Ambiente do preparo

3. Técnica do preparo do medicamento

$$
\begin{array}{ll}
( & \text { ) } \\
( & \text { ) } \\
( & ) \\
( & ) \\
( & ) \\
( & ) \\
( & ) \\
( & ) \\
( & ) \\
( & )
\end{array}
$$

4. Acondicionamento da medicação

5. Tipo do medicamento

6. Presença de prescrição médica

7. Interação com o paciente

8. Conferência do nome da medicação ao administrar

9. Registro do medicamento administrado

10. Condições gerais do paciente

Recursos audiovisuais: aparelho de TV, aparelho de vídeocassete e retroprojetor

\section{Referências}

CASSIANI, S.H.B. Erros na medicação: estratégias de prevenção. Revista Brasileira de Enfermagem, Brasília, v. 53, n.3, p.424-430, 2000b.

LEAPE,L.L. et al. Systems analysis of adverse drug events. JAMA, v. 274, n. 35-43, 1995. 


\section{APÊNDICE F - Termo de consentimento livre e esclarecido para participação em pesquisa}

Título da pesquisa: “Análise do sistema de medicação de um hospital universitário do Estado de Goiás”

Pesquisador: Prof ${ }^{a}$. Ana Elisa Bauer de Camargo Silva

\section{ESCLARECIMENTO AO PARTICIPANTE DA INVESTIGAÇÃO}

Você está sendo convidado(a) a participar de uma investigação cujo objetivo é identificar e avaliar aspectos no sistema de medicação do hospital que possam induzir a erros ou a erros potenciais na medicação nessa instituição. Sua participação é muito importante, uma vez que contribuirá para melhorar o sistema de medicação do hospital, resultando em maior segurança para os pacientes e profissionais, e na melhoria da qualidade da assistência prestada.

Informamos que a sua participação poderá ocorrer tanto de forma indireta, através de observação de suas atividades cotidianas, assim como de forma direta, respondendo a perguntas existentes em instrumentos de coleta de dados. As observações e as perguntas serão feitas pelo próprio pesquisador ou por enfermeiros que estarão atuando como auxiliares de pesquisa. As respostas poderão ser anotadas em folha de papel ou gravadas em fita cassete, para posterior transcrição para o papel.

Garantimos que durante a sua participação não haverá riscos, desconforto, tampouco custos. Asseguramos ainda que os dados obtidos serão utilizados unicamente para fins de pesquisa e que seu anonimato será preservado. 
Esclarecemos que você terá liberdade para desistir de sua participação da pesquisa em qualquer momento, sem qualquer penalidade, retirando seu consentimento em qualquer fase da pesquisa.

Pesquisador responsável

CONSENTIMENTO LIVRE E ESCLARECIDO PARA PARTICIPAÇÃO NA PESQUISA “ANÁLISE DO SISTEMA DE MEDICAÇÃO DE UM HOSPITAL UNIVERSITÁRIO DO ESTADO DE GOIÁS”

$\mathrm{Eu}$ Documento $\mathrm{n}^{\circ}$ , concordo em participar da pesquisa “Avaliação do Sistema de Medicação no Hospital Universitário de Goiás”, por livre e espontânea vontade, permitindo que as informações que prestarei sejam utilizadas para o desenvolvimento da mesma.

Declaro ter compreendido as informações oferecidas pelos pesquisadores e auxiliares de pesquisa, estando ciente dos objetivos e benefícios da mesma. Concordo com a publicação dos dados que tenham relação com o estudo, e aceito que sejam os mesmo inspecionados por pessoas autorizadas pelo pesquisador.

Goiás, de de 2002

Assinatura 
ANEXO A - Aprovação do Comitê de Ética em Pesquisa 
